PRÓ-REITORIA DE PESQUISA E PÓS-GRADUAÇÃO MESTRADO EM EDUCAÇÃO

FORMAÇÃO CONTINUADA DE PROFESSORES: APLICABILIDADE DE UM PROGRAMA

JOSETE GUARIENTO CARVELLI

Presidente Prudente - SP 
Dissertação apresentada a Pró-Reitoria de Pesquisa e Pós-Graduação, Universidade do Oeste Paulista, como parte dos requisitos para obtenção do título de Mestre em Educação Área de Concentração: Práxis Pedagógica e Gestão de Ambientes Educacionais

Orientadora:

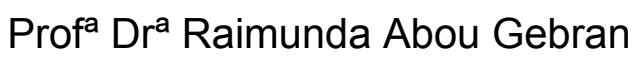


371.1 Carvelli, Josete Guariento

C331f Formação continuada de professores: aplicabilidade de um programa / Josete Guariento Carvelli. -Presidente Prudente: [s. n.], 2007.

$136 \mathrm{f}$. : il.

Dissertação (Mestrado em Educação)

Universidade do Oeste Paulista - UNOESTE: Presidente Prudente - SP, 2007.

Bibliografia

1. Professores -- Formação. 2. Educação permanente. 3. Formação profissional. I. Título. 
JOSETE GUARIENTO CARVELLI

FORMAÇÃO CONTINUADA DE PROFESSORES: APLICABILIDADE DE UM PROGRAMA

Dissertação apresentada a Pró-Reitoria de Pesquisa e Pós-Graduação, Universidade do Oeste Paulista, como parte dos requisitos obtenção do título de Mestre em Educação.

Presidente Prudente, 29 de novembro de 2007.

BANCA EXAMINADORA

Profa. Dra. Raimunda Abou Gebran

Universidade do Oeste Paulista - UNOESTE

Profa. Dra ${ }^{\mathrm{a}}$.Helena Faria de Barros

Universidade do Oeste Paulista - UNOESTE

Profa. Dra Maria Raquel Miotto Morelatti

Universidade Júlio de Mesquita Filho - UNESP 


\section{DEDICATÓRIA}

A meus pais, que, com exemplos de vida, formaram a personalidade;

À minha filha Keissy que compõe belos poemas e faz da linguagem instrumento de comunicação e sentimento;

A meu filho Kenny, que ama a linguagem através da música;

Ao meu esposo Urbano,que sempre calou, falou e incentivou nas horas certas;

Aos professores da Escola Estadual Fernando Costa com os quais convivi durante esta trajetória e que me ensinaram enquanto aprendiam.

Aos meus mestres que semearam em solo fértil;

Aos professores do curso que mostraram novos caminhos a percorrer.

Aos profissionais da educação como contribuição de experiência voltada para ensinar, mas, sobretudo, aprender constantemente. 


\section{AGRADECIMENTOS}

Agradeço a todos que neste trilhar estiveram próximos e, em especial, à professora orientadora Dra. Raimunda Abou Gebran pelas inferências precisas e as exigências que fizeram o caminhar seguro, sempre se pautando na ética e no conhecimento profundo.

Aos professores do mestrado, que desenvolveram os conteúdos de forma produtiva, com contribuições intensas e que contribuíram com conhecimentos específicos e semearam em solo fértil:

Prof ${ }^{a}$ Dra.Maria de Lourdes Zizi Trevisan

Prof. Dr. Adriano Rodrigues Ruiz

Profa Helena Faria de Barros

Prof. Dr. Levino Bertan

Prof. Dr. José Camilo Santos Filho

Aos professores da Escola Estadual Fernando Costa que permitiram o acompanhamento da aplicação e desenvolvimento do Programa, possibilitando assim esta pesquisa.

À minha família que soube gerenciar as ausências .

À Deus que está presente em cada pensamento. 
"Aprender é a única coisa de que a mente nunca se cansa, nunca tem medo e nunca se arrepende". 


\section{RESUMO}

\section{Formação continuada de professores: aplicabilidade de um programa}

A presente investigação buscou verificar as concepções dos professores, quanto à formação continuada em serviço durante o desenvolvimento do Programa Ensino Médio em Rede, que ocorreu em uma escola estadual no município de Presidente Prudente, instituído pela Secretaria de Estado da Educação do Estado de São Paulo. Esse Programa foi implantado no ano de 2004 e se estendeu até o ano de 2006 e tinha como objetivo capacitar os professores que atuam no Ensino Médio, proporcionando-Ihes um refletir sobre a própria prática educativa, estimulando a leitura e a produção de textos, a fim de alavancar o ensino público, que nos últimos anos vem demonstrando índices insatisfatórios nas avaliações externas aplicadas por diferentes instituições. Para tanto se optou pela utilização de pesquisa de abordagem qualitativa, descritiva e interpretativa da percepção dos sujeitoscolaboradores, por meio de entrevistas semi-estruturadas que interrogaram sobre o desenvolvimento do programa enquanto formação continuada em serviço. Por meio de questionário e entrevista, foi possível elaborar os dados em categorias para que a análise se tornasse possível A descrição e análise dos dados possibilitaram a partir da fala dos professores - colaboradores, perceber a concepção dos professores em relação ao desenvolvimento do Programa, enquanto formação específica dentro da modalidade. Concluímos que a formação continuada incentiva os professores e propõe um diálogo entre a teoria e ação educativa.

Palavras-chave: Formação contínua. Programa. Concepção dos professores. 


\section{ABSTRACT \\ Teachers' continuing education: the aplicability of the program}

This investigation aimed at verifying the teachers' conceptions as for the continuing education on service during the development of the Net High School Program, instituted by the State Department of Education of the State of São Paulo. This Program was implemented in the year of 2004 and extended up to the year of 2006, with the purpose of qualifying High School teachers, providing them with a reflection on the educational practice and stimulating reading and texts production in order to improve public education, which has been showing a knowledge deficit in the last years. Therefore, a research update was carried out with the use of descriptive, qualitative and interpretative approach of the subject-collaborators' perception, through semi-structured interviews enquiring about the development of the program as continuing education on service. Based on the teachers-collaborators' speech, the description and analysis made it possible to consider the teachers' conception regarding the applicability of the PROGRAM as specific education within the modality. The conclusion was that continuing education motivates the teachers and it proposes a dialogue between the theory and the education action.

Key-words: Continuing Education. Program. Teachers' conceptions. 


\section{LISTA DE QUADROS}

QUADRO 1 - Participantes do Programa Ensino Médio em Rede, na Diretoria de Ensino da Região de Presidente Prudente 2004

QUADRO 2 - Situação funcional dos professores que participam do programa Ensino Médio em Rede na E.E.Fernando Costa Ano Base 2004

QUADRO 3 - Organização dos alunos na Escola Estadual Fernando Costa - Ano Base 2006.

QUADRO 4 - Profissionais que atuaram na escola. Visão Geral. Ano Base 2006

QUADRO 5 - Qualificação dos docentes em 2006. 60

QUADRO 6 - Perfil dos participantes da pesquisa, de acordo com o tempo de serviço, na escola, qualificação profissional e carga horária. Ano Base 2006.

QUADRO 7 - Perfil dos participantes da pesquisa, de acordo com o tempo de serviço, na escola, qualificação profissional e carga horária.Ano Base 2006

QUADROS - Sínteses de acompanhamento do professor-coordenador

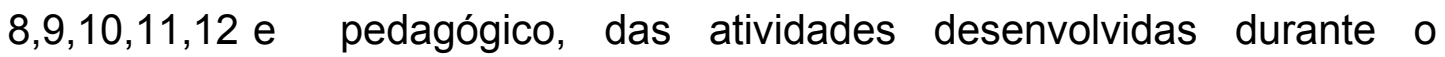
13 Programa: artigo de opinião.

QUADRO 14 - Síntese de acompanhamento da Vivência Educadora : Tema 1 
1 INTRODUÇÃO

2 FORMAÇÃO CONTINUADA DE PROFESSORES: PRESSUPOSTOS QUE

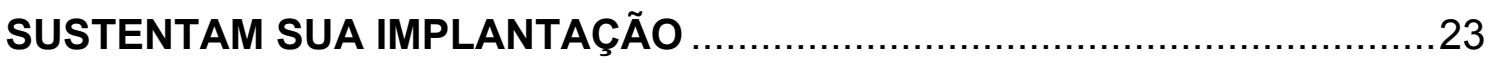

2.1 Embasamento Legal da Formação Continuada de Professores .......................28

2.2 O Papel da Formação Continuada ...................................................................

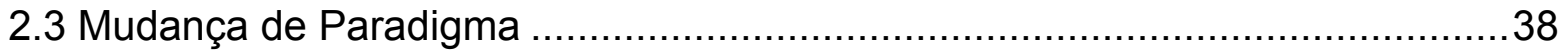

3 ENSINO MÉDIO EM REDE: UM PROGRAMA DE FORMAÇÃO

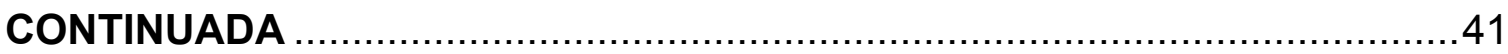

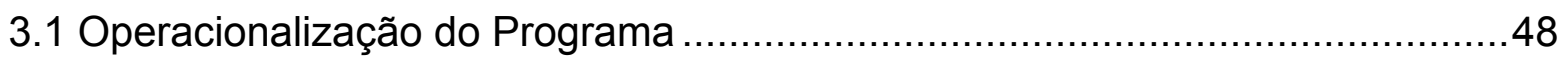

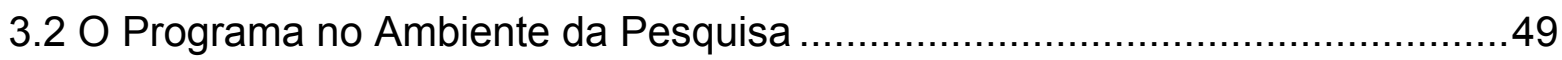

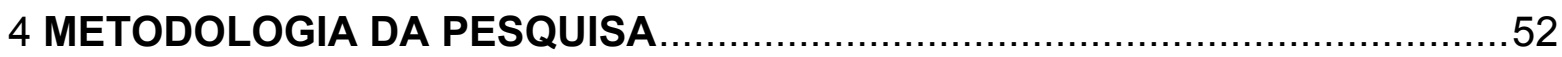

4.1 A Contextualização do Ambiente: a Instituição de Ensino.................................57

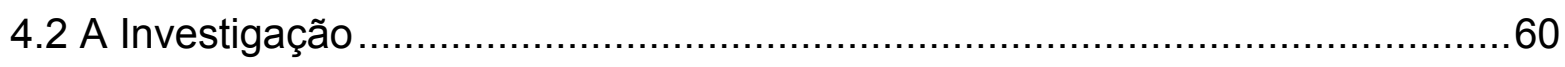

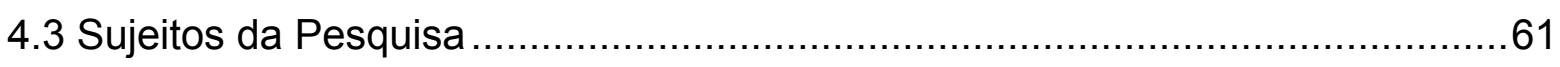

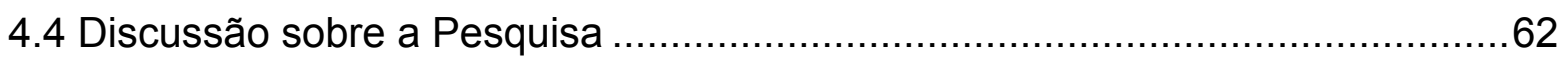

4.4.10s primeiros contatos com os objetivos do programa................................62

4.4.2 Procedimentos e instrumentos da coleta de dados.................................63

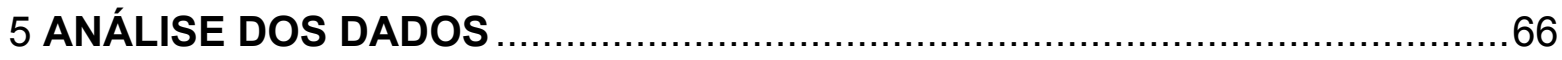

5.1 Razões da Busca da Formação Continuada ...............................................68

5.2 Percepção dos Professores Frente aos Objetivos do Programa ........................69

5.3 Integração/Articulação entre as Disciplinas .................................................70

5.4 Desenvolvimento de Competências e Habilidades........................................72

5.5 Utilização das Novas Tecnologias Metodológicas por Meio de Diversas

Mídias Interativas .74 
5.6 O Uso dos Ambientes de Ensino e Aprendizagem por Meio de

Mídias e Tecnologias na Concepção dos Professores.

5.7 Análise do Projeto Político Pedagógico..................................................... 76

5.8 Os Objetivos do Ensino Médio na Visão dos Professores............................... 77

5.9 Um Olhar Sobre as Observações dos Professores Sobre o Programa................79

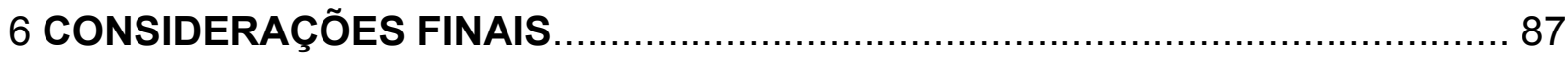

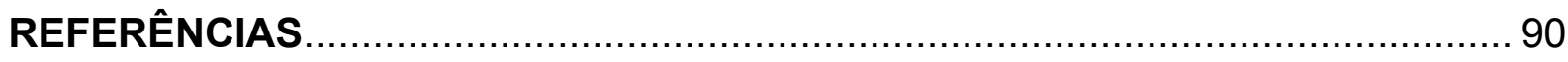

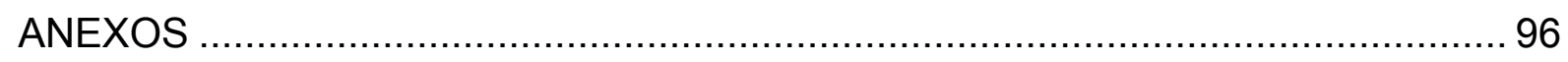

ANEXO 1 - TABELA DE RENDIMENTO ESCOLAR PARTE OBJETIVA ................. 97

ANEXO 2 - TABELA DE RENDIMENTO REDAÇÃO …………........................ 99

ANEXO 3 - ROTEIRO DE QUESTIONÁRIO ................................................... 101

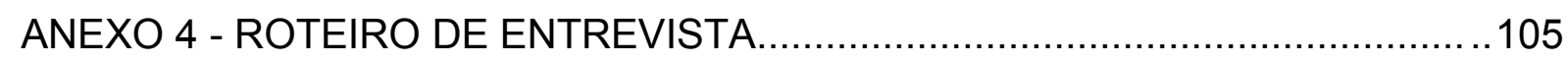

ANEXO 5 - QUADROS SÍNTESES DE ACOMPANHAMENTO DO

DESENVOLVIMENTO DO PROGRAMA ……………..................106

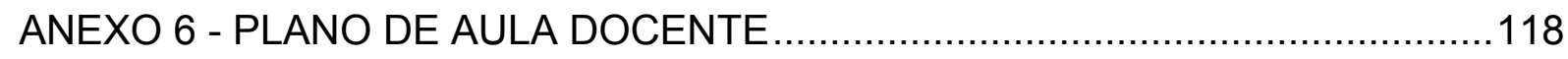

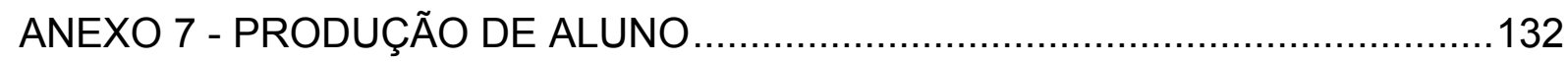




\section{INTRODUÇÃO}

"... o importante é que a reflexão seja um instrumento dinamizador entre teoria e prática." (FREIRE, 2003, p. 39).

O Brasil atravessa fase crítica em relação à educação. Por mais que se empenhem os educadores e as escolas, os resultados publicados pelo INEP/MECInstituto Nacional de Estudos e Pesquisas Educacionais Anísio Teixeira, demonstram que os índices são insatisfatórios. O balanço geral da nona edição do Exame Nacional do Ensino Médio, ENEM - 2006, apresenta as médias nacionais de desempenho na redação e parte objetiva da prova, abaixo da média, assim como as médias nas 27 unidades da Federação.

De acordo com os dados, os participantes do ENEM 2006 obtiveram médias de desempenho iguais a 36,90 na parte objetiva da prova e 52,08 na redação, numa escala que vai de 0 a 100. Um número elevado de participantes mais de 2,7 milhões (2.784.192) realizou o exame. Participaram da prova alunos que concluíram o ensino médio em 2006 e também os egressos, ou seja, aqueles que já haviam finalizado a educação básica em anos anteriores. Os egressos obtiveram médias de 38,14 na parte objetiva e 53,40 na redação, enquanto as médias entre os concluintes foram de 35,52 na parte objetiva e 50,72 na redação.

Os dados revelam ainda que os menores índices são de alunos oriundos de escola pública porque obtiveram médias 34,94 (prova objetiva) e 51,23 (redação), enquanto o grupo que declarou ter estudado somente em escola particular alcançou melhores índices porque obteve média igual a 50,57 na parte objetiva e 59,77 na redação, conforme apontam os dados inclusos no Anexo desta pesquisa.

Os recentes dados apontados por inúmeras fontes que buscam entender o momento atual educativo, ratificam a necessidade premente da formação continuada numa tentativa de elevar os índices de aprendizagem. Entre eles, o 
SAEB - Sistema de Avaliação da Educação Básica - que divulga os resultados de provas realizadas entre alunos da educação básica como demonstram as tabelas abaixo.

Percentual de alunos por resultado SAEB 1995/2005 - Leitura

TABELA 1 - Médias de Proficiência em Língua Portuguesa Brasil 1995 - 2005

$\begin{array}{llllllll}\text { Série } & 1995 & 1997 & 1999 & 2001 & 2003 & 2005 & \text { Dif. }\end{array}$

Sig.

4a Série do E.F. 188,3 (1,6) 186,5 (1,6) 170,7 (0,9) 165,1 (0,8) 169,4 (0,8) 172,3 (1,0) 2,9 *

8a Série do E.F. $256,1(1,4) 250,0(2,0) 232,9(1,0) 235,2(1,3) 232,0(1,0) 231,9(1,0)-0,1$

3a Série do E.M. $290,0(1,9) 283,9(2,1) 266,6(1,5) 262,3(1,4) 266,7(1,3) 257,6(1,6)-9,1$ *

O asterisco aparece na tabela e indica que a diferença é estatisticamente significativa para o nível de confiança de $95 \%$.

Fonte: INEP ( 1995/2005)

Percentual de alunos por resultado SAEB - 1995-2005. Matemática

\section{TABELA 2- Médias de Proficiência em Matemática Brasil 1995 - 2005}

$\begin{array}{llllllll}\text { Série } & 1995 & 1997 & 1999 & 2001 & 2003 & 2005 & \text { Dif. }\end{array}$

Sig.

4a Série do E.F. 190,6 (1,5) 190,8 $(1,2) 181,0(0,9) 176,3(0,8) 177,1(0,8) 182,4(0,9)$ 5,3 * 8 a Série do E.F. $253,2(1,9) 250,0(2,1) 246,4(1,1) 243,4(1,2) 245,0(1,1) 239,5(1,1) \quad-5,5$ * 3a Série do E.M. $281,9(2,6) 288,7(3,0) 280,3(1,7) 276,7(1,3) 278,7(1,4) 271,3(1,8)-7,4$ *

O asterisco aparece na tabela e indica que a diferença é estatisticamente significativa para o nível de confiança de $95 \%$.

Fonte: INEP (2001-2003).

Os dados acima demonstram que os alunos avaliados pelo SAEB Sistema de Avaliação da Educação Básica - que englobam escolas públicas e particulares de todo o país, apresentam índices insuficientes e justificam a formação continuada de professores.

De acordo com esses dados publicados pelo INEP (Instituto Nacional de Pesquisas Educacionais), os resultados não foram satisfatórios, seja em Leitura, Matemática seja em Ciências. Em Leitura, por exemplo, há grande porcentagem de alunos com resultados muito críticos, com conseqüências graves para sua formação. Em Matemática, os dados apresentam insatisfatórios. Os resultados dos dados com alunos de $8^{a}$ série apontam que $50 \%$ são considerados "críticos" com habilidades muito baixas para os mínimos considerados necessários. 
As avaliações realizadas pelo PISA - Programa Internacional de Avaliação de Alunos - ( Resultado Geral) demonstrado na tabela abaixo e em Anexo 1 e 2 ( Resultado da parte objetiva e redação ) nos revelam que na avaliação realizada entre trinta e dois países, o Brasil ocupa o último lugar com média de 396 pontos e o primeiro colocado obteve 546 na média geral entre os países ibero americanos.

\section{TABELA 3}

\begin{tabular}{|c|c|c|}
\hline \multicolumn{3}{|c|}{ PISA 2000-RESULTADO GERAL } \\
\hline & País & Média \\
\hline 1 & Finlândia & 546 \\
\hline 2 & Canadá & 534 \\
\hline 3 & Holanda & 532 \\
\hline 4 & Nova Zelândia & 529 \\
\hline 5 & Austrália & 528 \\
\hline 6 & Irlanda & 527 \\
\hline 7 & Coréia do Sul & 525 \\
\hline 8 & Reino Unido & 523 \\
\hline 9 & Japão & 522 \\
\hline 10 & Suécia & 516 \\
\hline 11 & Áustria & 507 \\
\hline 12 & Bélgica & 507 \\
\hline 13 & Islândia & 507 \\
\hline 14 & Noruega & 505 \\
\hline 15 & França & 505 \\
\hline 16 & Estados Unidos & 504 \\
\hline 17 & Dinamarca & 497 \\
\hline 18 & Suíça & 494 \\
\hline 19 & Espanha & 493 \\
\hline 20 & República Tcheca & 492 \\
\hline 21 & Itália & 487 \\
\hline 22 & Alemanha & 484 \\
\hline 23 & Liechtenstein & 483 \\
\hline 24 & Hungria & 480 \\
\hline 25 & Polônia & 479 \\
\hline 26 & Grécia & 474 \\
\hline 27 & Portugal & 470 \\
\hline 28 & Rússia & 462 \\
\hline 29 & Letônia & 458 \\
\hline 30 & Luxemburgo & 441 \\
\hline 31 & México & 422 \\
\hline 32 & Brasil & 396 \\
\hline
\end{tabular}

Esses dados colocam o país num patamar inferior frente a outros países, em relação à educação. Embora os dados acima se refiram ao ano de 2000, a situação, no Brasil, pouco mudou nos últimos anos. A partir desses dados 
apontados pelo PISA (Programa Internacional de Avaliação de alunos) que é um programa internacional de avaliação comparada, cuja principal finalidade é produzir indicadores sobre a efetividade dos sistemas educacionais, avalia-se o desempenho de alunos na faixa dos 15 anos, idade em que se pressupõe o término da escolaridade básica obrigatória na maioria dos países.

Em seu artigo, Bedaque (2006) publica os dados do PISA 2000 que tem o Brasil como o último colocado entre trinta e dois países, em uma prova com ênfase em leitura com abordagem em Ciências e Matemática. Em 2003, o PISA focou Matemática e os resultados do Brasil mostraram-se deficientes. De acordo com o autor ( 2006, p.29) "A performance alcançada pelos estudantes brasileiros no PISA 2000 e 2003 evidenciam uma baixa competência nas áreas de matemática, leitura, ciências e solução de problemas".

De acordo com o Instituto Nacional de Estudos e Pesquisa - INEP:

Alguns elementos avaliados pelo PISA, como o domínio de conhecimentos científicos básicos, fazem parte do currículo das escolas, porém o PISA pretende ir além desse conhecimento escolar, examinando a capacidade dos alunos de analisar, raciocinar e refletir ativamente sobre seus conhecimentos e experiências, enfocando competências que serão relevantes para suas vidas futuras.

(http://www.inep.gov.br/internacional/pisa/)

Mas o que avalia o PISA? Este Programa objetiva avaliar:

... até que ponto os alunos próximos do término da educação obrigatória adquiriram conhecimentos e habilidades essenciais para a participação efetiva na sociedade. Pretende responder a questões como:

Até que ponto os jovens adultos estão preparados para enfrentar os desafios do futuro? Eles são capazes de analisar, raciocinar e comunicar suas idéias efetivamente? Têm capacidade para continuar aprendendo pela vida toda? (http://www.inep.gov.br/internacional/pisa/)

Ao analisarmos os dados acima, percebemos que a má performance coloca os alunos na condição de pré-leitores. A partir desses dados, é preciso pensar a educação como prática reflexiva e à formação continuada deveria contribuir 
para que os professores também tivessem uma formação de professores-reflexivos sobre a prática, ou seja, eles próprios terão que constituir suas competências, criando dispositivos que favoreçam este processo em seus alunos, seguindo as orientações de Perrenoud (2002, p. 98):

Muitas vezes o ofício de professor é descrito como uma semi - profissão, caracterizada por semi-autonomia e por uma semi-responsabilidade. Para evoluir na profissionalização de seu ofício, os professores teriam de assumir riscos e deixar de usar como proteção o "sistema", o programa e os textos.

O fracasso escolar pode ser visto por diferentes ângulos: da sociedade, da escola e do aluno. De acordo com Weiss (1999, p. 16), no âmbito da sociedade, vários são os fatores que interferem e contribuem para essa queda na qualidade do ensino, como, por exemplo, ...o tipo de cultura,as condições sócio econômicas e políticas vigentes, o tipo de estrutura social, as ideologias dominantes $e$ as relações explícitas desses aspectos com a educação. As condições sócioeconômicas do país que não oferecem para as camadas sociais menos favorecidas, melhores perspectivas de vida.

No aspecto relacionado à escola, percebemos que há interferência quanto à metodologia utilizada, à interpretação errônea das teorias e métodos aplicados, à concepção de alfabetização e letramento ${ }^{1}$ de cada professor, à avaliação punitiva, e no. que se refere ao aluno, além dos fatores psicológicos, emocionais, cognitivos, à bagagem cultural de cada criança, já que reflete o grau de acesso da família ao conhecimento e à aquisição de livros e outros fatores que causam obstáculos, mas não são determinantes.

\footnotetext{
1 Letramento, aqui entendido como produto da participação na vida social que utiliza a escrita e a leitura como sistema simbólico, com significado.O sentido ampliado da alfabetização, o letramento, de acordo com Magda Soares(2003,p.1), "designa práticas de leitura e escrita. A entrada da pessoa no mundo da escrita se dá pela aprendizagem de toda a complexa tecnologia envolvida no aprendizado do ato de ler e escrever". O indivíduo no uso das atividades de leitura e escrita. Envolve o fazer uso da leitura e escrita, compreendendo seus significados.
} 
Nessa pesquisa faremos um recorte nesses aspectos e abordaremos a formação continuada do professor como importante papel na construção do conhecimento pelo aluno e acreditamos que a formação continuada do professor contribuirá para a qualidade do ensino e aprendizagem.

Nesse sentido, a formação profissional do educador precisa estar à frente das demandas por tratar-se, implicitamente, da formação de alunos. Aprimorar-se constantemente significa como nos revela Fusari $(1998$, p.26) ... colocar realidade no contexto mais amplo da democratização do ensino e da própria sociedade brasileira. Isto significa assumir a formação do educador em serviço, como um meio e não como um fim em si.

Acreditamos que a formação em serviço, contribuirá para o trabalho de professores mais competentes e, como competência, nos embasamos nas argüições de Lopes e Macedo (2002, p.122) e entendemos " ...mobilização de diferentes esquemas para atuar em uma situação específica...".

De acordo com os Parâmetros Curriculares Nacionais para o Ensino Médio - PCNs (2000) - documentos que norteiam a educação e que foram elaborados para difundir os princípios da reforma curricular e orientar os professores na busca de novas abordagens e metodologias; entre as funções da escola está o compromisso em desenvolver competências nos alunos, como a mobilização de conhecimentos (saber), habilidades (fazer) e atitudes (querer), necessários ao desempenho de atividades ou funções, segundo padrões de qualidade e produtividade requeridos pela natureza do trabalho.

Atualmente a inserção no mercado de trabalho exige níveis cada vez mais altos de escolarização geral, e a escola não pode ficar reduzida à aprendizagem de algumas habilidades. A escola tem como objetivo maior oferecer a todos uma cultura básica comum. Sem renunciar à diversificação, seu desafio vai além: conseguir que todos os alunos tenham acesso a essa cultura e dela se apropriem. Fica cada vez mais evidente que, de forma complementar à importante atuação do professor em sala de aula, ocorrem significativos processos educativos nos demais ambientes da escola. Esses processos de comunicação, interação e de vivência coletiva colocam em cena os docentes.

Torna-se necessário, portanto, que se capacitem os professores 
para que se tornem capazes de desempenhar os novos papéis que a escola exige, ou seja, de atuação na sociedade como cidadãos participativos, críticos, conscientes e transformadores.

A Secretaria de Estado da Educação, no Estado de São Paulo, em 2004, implantou o Programa Ensino Médio em Rede que tem como objetivo maior qualificar os professores, proporcionando-lhes a condição necessária à sua responsabilidade social no processo educativo.

Dessa forma, está sendo estabelecida uma política de valorização dos educadores que engloba diversos aspectos, como reconhecimento profissional carreira e formação profissional continuada. Essa política de valorização é construída em parceria com alguns segmentos, quais sejam: Banco Interamericano de Investimento - BID - Secretaria de Educação Média e Tecnológica - Ministério da Educação, Programa de Melhoria do Ensino Médio - PROMED, Fundação Vanzolini, Secretaria de Estado da Educação.

A Secretaria de Estado da Educação, do Estado de São Paulo, na última década, tem proporcionado capacitações, treinamentos, cursos, palestras e Fóruns entre outros, organizados por especialistas, para contribuir com a qualificação dos professores, porém os resultados ainda parecem ser negativos.

Nesta pesquisa, procuramos analisar o resultado da formação continuada e as concepções de um grupo de professores que atuam em uma escola vinculada à Secretaria de Estado da Educação, do Estado de São Paulo. Na Escola Estadual Fernando Costa, em Presidente Prudente, onde atuamos como diretora, há educadores realizando o projeto Ensino Médio em Rede. Sendo assim, utilizamo-nos desta escola para observarmos a aplicação do referido programa.

Objetivamos analisar a concepção dos professores durante o desenvolvimento do programa, ou seja, como esses professores se posicionam em relação ao programa. Nesse sentido, procuramos verificar, em um grupo de dez professores efetivos, quais as contribuições que o programa proporcionou em sua formação continuada, quais os motivos que os levaram a participar desse programa e quais os benefícios recebidos.

Buscamos com a pesquisa, sem sermos pretensiosos, fornecer dados para subsidiar outras capacitações em serviço, que visem à qualidade do ensino e 
aprendizagem.

Procuramos analisar os documentos que foram fornecidos aos professores, tais como: material impresso, CD com parte teórica apresentado em forma oral e os objetivos do programa disponível em site da Secretaria de Estado da Educação.

No ambiente desta pesquisa, há vinte e dois professores participando do Programa, mas optamos por analisar a participação de dez professores efetivos e um professor coordenador, da Escola Estadual Fernando Costa, em Presidente Prudente, Estado de São Paulo.

Utilizamos como instrumento de coleta de dados: entrevistas, questionário, observação durante os Horários de Trabalho Pedagógico Coletivo HTPC -em que eram discutidos os temas e as reflexões aconteciam e análise documental, objetivando perceber a concepção dos professores frente a essas capacitações e perceber como nos aponta Neves (2002, p. 137):

...que o educador tende a reproduzir métodos e estratégias que foram utilizados durante seu processo de formação. Assim, um curso pedagogicamente pobre pode levar o educador a trabalhar com seus alunos de uma forma também pobre. Ou a exigir desse educador um enorme esforço para vencer as deficiências que enfrentou.

A mediação didática não pode ser vista como mera técnica para ensinar qualquer coisa a qualquer um. Requer a contextualização do processo pedagógico, pois, de acordo com essa concepção, a capacitação em serviço é vista como processo educativo que consiste na aprendizagem constante, na aquisição de novos conhecimentos e não apenas instrutivo, como se o professor recebesse instruções para desenvolver seu trabalho.

Diante de tal situação, interessamo-nos em saber se essas capacitações eram de interesse dos professores, além da busca pelos certificados. Entre tantos cursos, capacitações e programas, buscamos perceber qual a concepção dos professores frente a essa formação contínua. Para isso, fizemos um recorte e focamos especificamente o Programa Ensino Médio em Rede.

Nosso interesse pela formação continuada é de longa data. Enquanto aluna do curso de Pedagogia na Faculdade de Educação de Presidente Venceslau, 
havia sempre o questionamento: Por que os professores buscam a formação continuada?

Para aprofundarmos os conhecimentos, ingressamos no Curso de Especialização, (Lato Senso) em Psicopedagogia, na Faculdade de Educação de Presidente Venceslau, e os questionamentos continuavam. Havia muitas contradições porque percebíamos que alguns professores aprendiam com as teorias e não modificavam a prática, então qual o motivo do professor em buscar a formação continuada?

Ao ingressarmos como diretora de escola, pudemos perceber que a Secretaria de Estado de Educação do Estado de São Paulo tem investido na formação continuada para todos os educadores da rede. Em 2002, participamos de curso de formação continuada - Circuito Gestão, que contribuiu com nossa prática em gestão, pois focou aspectos relevantes da ação de direção de escola. No curso de especialização em gestão na UNICAMP, estivemos em contato com diferentes professores que contribuíram para uma prática educativa mais elaborada, o que nos levou a refletir sobre a prática gestora e a colocar em ação os novos conhecimentos na unidade escolar onde atuamos como diretora.

Os professores, ao longo de sua carreira educacional, participam de cursos que thes são oferecidos pela Secretaria de Estado da Educação, porém, muitas vezes, isso nos leva a refletir que os professores participam da formação continuada em serviço, contudo não lhes são cobradas devolutivas e se isso não ocorre nada muda no cotidiano, assim como outros assuntos abordados nessa formação continuam, que nem sempre estão diretamente articulados à prática pedagógica do professor.

Diante de tantas interrogações, o foco da pesquisa esteve voltado para a observação e análise da formação continuada em serviço, de um grupo de professores, que atuam na rede pública do Estado de São Paulo, e que estão participando do Projeto Ensino Médio em Rede, oferecido pela Secretaria de Estado da Educação do Estado de São Paulo. Esses educadores atuam em uma escola que atende o Ensino Fundamental e Médio, porém o foco está no Ensino Médio. Procuramos perceber qual a concepção desses professores em relação à essa formação continuada, as contribuições que o programa proporcionou em sua 
formação continuada e quais os motivos que os levaram a participar desse programa.

Foram observados, como sujeitos da pesquisa, dez educadores, descritos mais adiante, de diferentes disciplinas abrangendo as três áreas de conhecimento: Linguagens, Códigos e suas Tecnologias, Ciências da Natureza, Matemática e suas Tecnologias e Ciências Humanas e suas Tecnologias que atuam no Ensino Médio, por tratar-se de um programa de formação de professores de Educação Básica voltado para o desenvolvimento curricular do Ensino Médio. Além disso, na formação pressupõe-se o uso dos ambientes de ensino e aprendizagem e as mídias e tecnologias da Rede do Saber - teleconferências, videoconferências e web, além de materiais de apoio especialmente desenvolvidos para o programa.

No Capítulo I, focamos o embasamento legal que legitima a formação continuada de professores, bem como as Leis e Resoluções que definem as modalidades. Procuramos refletir sobre a formação continuada e as características que contribuíram para que enriquecesse o trabalho dos professores. Buscamos embasamento teórico com alguns pensadores como Cro, Fusari, Nóvoa, Perrenoud, entre outros, que ora compartilham as idéias, ora as opiniões são contrárias, trilhando com isso um caminho de indagações, incertezas e convergências.

Neste capítulo situamos o campo da pesquisa, focamos algumas definições sobre os termos utilizados na formação continuada, pinçamos algumas resoluções que dão legalidade à sua implementação. Jogamos luzes sobre o papel da formação continuada, o que consiste em refletir sobre os objetivos dessa formação. Promovemos também breve retrospectiva sobre a formação continuada de professores e apontamos alguns dados sobre o rendimento escolar dos alunos.

No Capítulo II, abrimos um panorama sobre o Programa Ensino Médio em Rede, sua organização e desenvolvimento.

Já no Capítulo III, discorremos sobre a Metodologia utilizada, baseada em alguns autores que explanam sobre o assunto. Demonstramos a contextualização do ambiente da pesquisa e traçamos o perfil da escola.

O Capítulo IV, traz a análise dos dados, em que procuramos demonstrar, em aplicabilidade do Programa Ensino Médio em Rede, suas 
dificuldades e sucessos. Interessante constatar as "falas" dos professores envolvidos que demonstram os anseios, as buscas, as concepções e a realização dos projetos.

As Considerações Finais abordam as conclusões a que chegamos, sem fechar o assunto; pelo contrário, abrem discussões sobre a formação continuada em serviço. 


\section{FORMAÇÃO CONTINUADA DE PROFESSORES: PRESSUPOSTOS QUE SUSTENTAM SUA IMPLANTAÇÃO}

...para além de formação escolar, de formação oferecida pela CENP,pelas Universidades e pela FDE, a competência dos educadores necessita ser formada no cotidiano do trabalho do infra-escolar, na dinâmica da Unidade Escolar, no dia-a-dia, na sala de aula, na rotina da escola enfim. (FUSARI, 1992, p. 30).

Numa breve retrospectiva a respeito das discussões no Brasil sobre a formação continuada de professores, observa-se que, nos últimos anos, são muitas as iniciativas por parte das instituições públicas ou privadas, no sentido de desenvolver um trabalho significativo na linha da formação continuada de professores. Por meio de inúmeros projetos, foram vivenciadas diferentes tendências pedagógicas como o behaviorismo ${ }^{2}$, escolanovismo ${ }^{3}$, o tecnicismo 4 e, nos últimos anos, essas tendências vêm vem fundamentando-se nas linhas progressistas do construtivismo ${ }^{5}$.

\footnotetext{
2 Palavra inglesa behaviour(RU) ou behavior (EUA) significa comportamento, conduta. Os behavioristas de orientação positivista trabalham com o princípio de que a conduta dos indivíduos é observável, mensurável e controlável similarmente aos fatos e eventos nas ciências naturais e nas exatas.

${ }^{3}$ Escolanovismo, que no Brasil teve como representante Anísio Teixeira cujas bases encontram-se no escolanovismo surgido em fins do século XIX, na Europa e nos Estados Unidos. Cujo movimento opunha-se às práticas pedagógicas tidas como tradicionais, buscando uma educação que pudesse integrar o indivíduo na sociedade e, ao mesmo tempo, ampliar o acesso de todos à escola.

4 As teorias do tecnicismo foram amplamente divulgada nos anos 70, aplicando-se o que se chamou de "tecnicismo educacional". Baseadas nas teorias behavioristas da aprendizagem e da abordagem sistêmica do ensino, que definiu uma prática pedagógica altamente controlada e dirigida pelo professor.As propostas educacionais baseavam-se em atividades mecânicas,rígida e passível de ser totalmente programada em detalhes.Valorizava a tecnologia programada de ensino.Tinha como mote a falsa idéia de que aprender não é algo natural do ser humano, mas que depende exclusivamente de especialistas e de técnicas. Disponível em www.centrorefeducacional.com.br
}

50 construtivismo é uma teoria epistemológica, que teve como representante Piaget . Foi concebido como uma forma de explicar a realidade da produção de conhecimento. Mais precisamente o conhecimento científico. 
No final do século $X X$, a educação passou por transformação, no sentido de formação de professores. Essa formação, conforme Perrenoud (2002) passou por momentos cujos objetivos consistiam em que os professores internalizassem as teorias e colocassem em prática em suas classes, em alguns casos, sem levar em consideração a distância entre as práticas vigentes e as inovações, sem oportunizar um tempo para reflexão, sem acompanhar a implantação (pedagogia por objetivos, teoria dos tipos de texto, princípios da avaliação formativa, recurso à metacognição, trabalho por meio de situaçõesproblema).

O momento histórico, de acordo com Barilli (1998), caracterizava-se pela necessidade de uma renovação do saber-fazer educativo, tanto no que se refere à atualização em relação aos conhecimentos específicos das disciplinas pela qual o professor é responsável, como também por uma razão premente, quanto ao que se refere à própria natureza do fazer pedagógico, isto é, o domínio da práxis, que é histórico e inacabado (BARBIERI et al., apud BARILLI, 1998, p.44).

Durante os anos 70 e meados dos anos 90 do século passado, a atualização era vista como aquisição de informações científicas, didáticas e psicopedagógicas, descontextualizadas da prática educativa do professor.

Após vários estudos, abandonou-se esse conceito e a prática educativa passou a ser entendida como um momento de reflexão e orientação fundamental, a partir da construção de conhecimentos e teorias baseadas na prática docente, enfatizando-se reflexão crítica do contexto.

Assim em Imbernón (2001, p.48-49), vê-se confirmado este conceito:

\begin{abstract}
A formação terá como base uma reflexão dos sujeitos sobre sua prática docente, de modo a permitir que examinem suas teorias implícitas, seus esquemas de funcionamento, suas atitudes etc., realizando um processo constante de auto-avaliação que oriente seu trabalho. A orientação para esse processo de reflexão exige uma proposta crítica da intervenção educativa, uma análise da prática do ponto de vista dos pressupostos ideológicos e comportamentais subjacentes.
\end{abstract}

Ainda em Imbernóm (2002, p.45-46), há uma definição de desenvolvimento profissional, que vê a formação como mais um elemento e não como o único, qualquer intenção sistemática de melhorar a prática profissional, 
crenças e conhecimentos profissionais, com o objetivo de aumentar a qualidade docente, de pesquisa e de gestão, é válida, que comunga com nossa postura frente a essa busca, ou seja, há diversas maneiras de crescer profissionalmente, entre elas, a busca individual e/ou a coletiva, quer seja pela oferecida pela própria instituição onde trabalhamos, que seja por iniciativa própria em outras instituições

Nos anos 90 essa formação deu-se também, a partir de atividades múltiplas, descontínuas e desvinculadas da prática docente. Cró (1998, p.75) ao citar Schön, aponta que "a formação contínua deveria apoiar uma aprendizagem que finalmente conduzisse a uma mudança da prática de ensino pela reflexão na acção e depois da acção".

Emergindo com grande força das discussões referentes à educação, a questão da formação continuada de professores tem apontado para a necessidade de encaminhamento de propostas, de programas, de cursos e de projetos de formação.

Alguns termos foram utilizados como recyclage na França, aggiornamento na Itália, para designar a formação continuada. Alguns termos foram e continuam sendo usado como reciclagem, atualização, treinamento, aperfeiçoamento, capacitação. Algumas denominações, entretanto, estão equivocadas porque estão esvaídas de sentido, ou ainda, com conceitos deturpados em relação ao que deveria ser a formação contínua. Nos anos 70 , por exemplo, o termo reciclagem era comumente utilizado. Capacitam-se aqueles sem capacidades ou incapazes.

Importante, neste momento, conceituar alguns termos amplamente difundidos, mas que, inúmeras vezes, passaram sem que se refletisse sobre suas concepções.

Ao nos depararmos com explanações de Marin (1995), encontramos a análise de termos que se torna imprescindível colocar em pauta, já que tais termos são equivalentes e não sinônimos e seu uso demonstra muitas vezes as concepções implícitas.

O termo reciclagem refere-se a processo de reciclagem de materiais, muitas vezes descartáveis e quando utilizados no contexto educacional, subentende-se curso rápido; sem contexto e superficial, deixando de expressar o 
processo ensino e aprendizagem.

Outro termo erroneamente utilizado refere-se a treinamento, visto que a educação, ao ser vista como ato mecânico, que modela comportamento, deixa de ser vista como processo e parte integrante de um contexto.

Da mesma forma, aperfeiçoamento, entendido como um conjunto de ações, promovido para completar alguém, ou torná-lo perfeito, deve ser evitado.

Marin (1995) considera também que o termo capacitação, pode ter o sentido de convencimento e persuasão, dessa forma se torna inadequado para ações de formação continuada.

No caso específico do Estado da São Paulo, a Secretaria da Educação publicou a Resolução $\mathrm{n}^{\circ}$. 62, de 9 de agosto de 2005 que dispõe sobre procedimentos para implementação das ações de formação continuada, nas modalidades Curso e Orientação Técnica.

Essa Resolução define ações de formação continuada, nas modalidades Curso e Orientação Técnica, desenvolvidas por órgãos da Secretaria da Educação e/ou com sua aprovação, algumas modalidades, a saber:

- Curso: conjunto de estudos, oficinas, vivências, encontros, fóruns, seminários, workshops, videoconferências, aulas, conferências, palestras ou outros, realizados também no exterior, presenciais ou a distância, que tratem de determinada unidade temática, constituinte de um todo, previamente definido e estruturado.

- Orientação Técnica: ação articulada ou reunião de caráter sistemático ou circunstancial, que subsidie a atuação profissional na implementação de diretrizes e procedimentos técnico-administrativo e técnico-pedagógicos e curriculares da educação básica.

Por sua vez o termo atual mais adequadamente utilizado refere-se à educação continuada, pois se considera a ação de capacitar no sentido de tornar capaz, habilitar, analisar, criticar e ou aceitar, sendo assim mais amplo, enriquecedor.

Com essa concepção, optamos pelo uso de formação continuada, 
entendida nesta pesquisa como o processo de formação de educadores que estão atuando, inseridos num contexto sócio - histórico que tem como função atuar de maneira a ser mediador de conhecimento, transformador da realidade.

Inúmeros estudiosos têm se debruçado sobre essa tendência mundial de formação continuada. Com o desencadeamento das contribuições de alguns filósofos e pedagogos e bem articulado por Schön (1992) sobre a importância do professor - reflexivo; cada vez mais há necessidade de valorizar os saberes docentes e o auto - conhecimento. Quando a reflexão sobre a prática permear o trabalho do educador, a formação continuada será exigência "sine qua non" para que o professor se mantenha atualizado, energizado, atuante no seu espaço histórico, crescendo no saber e na forma de atuar.

Toda formação continuada deveria pautar-se em atividades realizadas pelos alunos-educadores para implementar novos conhecimentos e que, refletindo sobre seus conhecimentos prévios, acarreta-se o surgimento de novas ações pedagógicas. Assim nesse processo dialógico, segundo as concepções de Becker (2007, p.87,88), a formação contínua seria baseada no construtivismo:

\begin{abstract}
Construtivismo significa isto: a idéia de que nada, a rigor, está pronto, acabado, e de que,especificamente, o conhecimento não é dado, em nenhuma instância, como algo terminado. Ele se constitui pela interação do Indivíduo com o meio físico e social, com o simbolismo humano, com o mundo das relações sociais; e se constitui por força de sua ação e não por qualquer dotação prévia, na bagagem hereditária ou no meio, de tal modo que podemos afirmar que antes da ação não há psiquismo nem consciência e, muito menos, pensamento.
\end{abstract}

No contexto brasileiro, após a promulgação da Constituição Federal de 1988 e da Lei de Diretrizes e Bases da Educação - LDB desencadeou-se uma busca incessante pela formação continuada, como sinônimo de avanço educacional e novos certificados, nos mais variados sistemas de ensino, decorrentes do plano de carreira, com ênfase na melhoria e qualidade do ensino.

Em se tratando de formação continuada de professores, estamos nos reportando à formação de adultos que possuem bagagem cultural e social. Nesse contexto, Canário (2000, p.21) nos aponta alguns princípios que embasam toda e qualquer processo formativo de adultos: 
$1^{\circ}$ Princípio: "O adulto em situação de formação é portador de uma história de vida e de uma experiência profissional (...)"; $2^{\circ}$ Princípio: "A formação é sempre um processo de transformação individual, na tripla dimensão do saber (conhecimentos), do saber fazer (capacidades) e do saber ser (atitudes) (...)" ; $3^{\circ}$ Princípio: "A formação é sempre um processo de mudança institucional, devendo, por isso estar intimamente articulada com as instituições onde os formandos exercem sua actividade profissional (...)"; $4^{\circ}$ Princípio: "Formar não é ensinar às pessoas determinados conteúdos, mas sim trabalhar colectivamente em torno da resolução de problemas.

A formação faz-se na 'produção' e não no 'consumo' do saber (...)"; $5^{\circ}$ Princípio: “ A formação deve ter um cariz essencialmente estratégico, preocupando-se em desenvolver nos formandos as competências necessárias para mobilizarem em situações concretas os recursos teóricos e técnicos adquiridos durante a formação." $6^{\circ}$ Princípio: "E não esqueçamos nunca que, como dizia Sartre, o homem caracteriza-se sobretudo, pela capacidade de ultrapassar situações pelo que consegue fazer como que os outros fizeram dele. A formação tem de passar por aqui.

Isso implica a necessidade de se buscar uma ressignificação tanto para a formação continuada de professores, como também para o conceito de prática pedagógica, sobre a qual Freire $(1983$, p.68) tão bem dissertou [...] $a$ educação problematizadora coloca, desde logo, a existência da superação da contradição educador-educandos. Sem esta, não é possível a relação dialógica [...].

Ao ressignificar o conceito de prática pedagógica, torna-se necessário contextualizar em relação aos fatores socioeconômico-culturais, o que implica uma ruptura com a visão ingênua da realidade e transcende a racionalidade técnica,baseada no taylorismo que concebe o exercício profissional como uma atividade meramente instrumental, voltada para a solução de problemas a eficiência condicionante da rotina, o legal, o instituído.

\subsection{Embasamento Legal da Formação Continuada de Professores}

Toda ação educativa reporta-se à legislação que orienta, define regras norteando as ações. A formação continuada de professores está embasada em legislação para assegurar a implantação e implementação, referenciada em uma 
política educacional, que privilegia o aprimoramento da profissão.

A partir da publicação do Plano Decenal de Educação para Todos, documento elaborado em 1993 pelo Ministério da Educação (MEC) destinado a cumprir, no período de uma década (1993 a 2003), as resoluções da Conferência Mundial de Educação Para Todos, realizada em Jomtien, na Tailândia, em 1990, pela Unesco (Organização das Nações Unidas para a Educação), Unicef (Fundos das Nações Unidas para a Infância), PNUD (Programa das Nações Unidas para o Desenvolvimento) e Banco Mundial, estabeleceu-se a posição consensual na luta pela satisfação das necessidades básicas de aprendizagem para todos. Esses documentos são considerados um conjunto de diretrizes políticas voltado para a recuperação da escola fundamental no país.

Os objetivos do Plano Decenal de Educação para Todos formam a base da Lei de Diretrizes e Bases da Educação Nacional, LDB - aprovada em 1996, ao consolidar e ampliar o dever do poder público com a educação em geral e, em particular, com o ensino fundamental.

A Constituição Federal de 1988, assim como a Constituição do Estado de São Paulo de 1989 ,a Lei de Diretrizes e Bases da Educação Nacional - LDB, de 1996, tratam da obrigação da União, dos Estados, dos Municípios e do Distrito Federal de elaborarem seus respectivos planos plurianuais de educação. A Lei de Diretrizes e Bases da Educação Nacional - LDB nº. 9.394, de 20 de dezembro de 1996, no disposto no Título VI - Dos Profissionais da Educação aponta para as questões relacionadas à formação continuada como pode ser observado:

- no Art. 61: A formação de profissionais da educação, de modo a atender aos objetivos dos diferentes níveis e modalidades de ensino e às características de cada fase do desenvolvimento do educando, terá como fundamentos:

I - a associação entre teorias e práticas, inclusive mediante a capacitação em serviço.

- no Art. 63: Os Institutos Superiores de Educação manterão: 
Regulamentado pelo Decreto $n^{\circ}$. 3276/99, no Capítulo III programas de educação continuada para os profissionais de educação dos diversos níveis;

- no Art. 67: Os sistemas de ensino promoverão a valorização dos profissionais da educação, assegurando-lhes, inclusive nos termos dos estatutos e dos planos de carreira do magistério público:

II - aperfeiçoamento profissional continuado, inclusive com licenciamento periódico remunerado para esse fim;

Ainda a mesma Lei, no Título IX - Das Disposições Transitórias, no Capítulo III - delibera em seu parágrafo $3^{\circ}$ que: "Cada Município e, supletivamente, - Estado e a União deverão realizar programas de capacitação para todos os professores em exercício, utilizando também, para isto, os recursos da educação à distância"

Assim, inúmeros cursos, capacitações, oficinas e orientações técnicas são disponibilizados aos professores, durante o ano letivo, na busca da melhoria e qualidade do ensino. Nesse enfoque Neves (2005, p.137) aponta:

Se a escola deve mudar, certamente os cursos de formação de professores precisam também passar por uma mudança profunda e radical. Todas as características da escola contemporânea antes apresentadas devem estar presentes nos cursos que formam os profissionais da educação. O cotidiano da formação dos educadores deve ser marcado por um diálogo interativo entre ciência, cultura, teorias da aprendizagem, gestão da sala de aula e da escola, atividades pedagógicas e domínio das tecnologias que facilitam o acesso à informação e à pesquisa.

Têm sido freqüentes as afirmações de que a educação pública não oferece qualidade, que os "anos de ouro da educação" ficaram congelados nos idos de 1950; porém, muitos autores contemporâneos afirmam que os anos de ouro nunca ocorreram e que a educação sempre teve e sempre terá problemas. Nesse sentido o papel da formação continuada tem desencadeado importantes reflexões. 


\subsection{O Papel da Formação Continuada}

Diversos fatores induzem os professores a participarem da formação continuada. Alguns buscam conhecimentos, atualização, outros ganhar créditos, promoção via não acadêmica, sair da sala de aula, etc. A discussão sobre a formação continuada de professores, remete à reflexão sobre quais seriam as características que contribuiriam para a formação contínua, que enriquecesse o trabalho dos professores.

Para Cró $(1998$, p.77) O professor e o educador aprenderiam a sua profissão pelo processo de reflexão. Nesta perspectiva, a formação visaria, sobretudo, desenvolver habilidades do educador através da reflexão sobre a prática. Comungamos com a idéia visto que há necessidade de refletir sobre a prática, embasados em teorias, para poder entendê-la, reformulá-la quando necessário ou reafirmá-la, mas alguns professores sentem dificuldades em vincular a intenção da formação com sua prática.

Há dificuldades na realização da formação continuada no formato de alguns cursos porque são realizados aos finais de semana, o que tem sido alvo de reclamações de muitos educadores que vêem, nesse tempo, espaço para o lazer e para a família.

A formação continuada realizada no período de aula implica dispensa dos alunos ou outro aspecto bem delicado, ou seja, a colocação de professor substituto para o cumprimento dos dias letivos, deixando muitas vezes de dar continuidade ao conteúdo iniciado pelo titular da classe. Estabelecer a formação na escola, durante o período da aula, atinge somente parte dos professores, porque com o número elevado de aulas os professores trabalham em várias escolas ao mesmo tempo.

A formação continuada na escola consiste na qualidade da educação, buscando profissionais bem qualificados. Assim, encontrar o melhor caminho para a formação continuada torna-se imprescindível. A formação continuada é motivo de discussão em muitos países que primam pela qualidade do ensino.

Isso nos remete a uma questão: qual o papel da formação continuada? 
Podemos responder utilizando os apontamentos de Cró (1998, p.77) quando nos fala que essa questão apresenta dois pólos: de um ângulo a formação visa à transmissão de teorias que são elaboradas em academias, o que gera insatisfação na classe de professores ou deixa de atingir os objetivos propostos visto que os professores não percebem a relação teoria e prática, e assim a prática não muda. Por outro ângulo, o processo se daria através da reflexão sobre a prática educativa que deveria ser acompanhada por especialistas, de maneira contínua e sistemática.

Nesse sentido, Rodrigues e Esteves (1993, p.66) apontam algumas características da formação continuada:

\begin{abstract}
Uma ruptura com o individualismo pedagógico, ou seja, em que o trabalho e a reflexão em equipe se tornam necessários; uma análise científica da prática, permitindo desenvolver, com uma formação de nível elevado, um estatuto profissional; um profissionalismo aberto, isto é, em que o ato de ensino é precedido de uma pesquisa de informações e de um diálogo entre os parceiros interessados.
\end{abstract}

Neste contexto a figura o professor fica evidenciada. Nóvoa (1999, p.2) traz à tona o diálogo:

\begin{abstract}
Nos dias de hoje, há uma retórica cada vez mais abundante sobre o papel fundamental que os professores serão chamados a desempenhar na construção da "sociedade do futuro". Um pouco por todo o lado, políticos e intelectuais juntam as suas vozes clamando pela dignificação dos professores, pela valorização da profissão docente, por uma maior autonomia profissional, por uma melhor imagem social etc. (...) Nos programas de ação política ou nos discursos reformadores, nos documentos dos "especialistas" da União Européia ou na literatura produzida pelos investigadores, reencontramos sempre as mesmas palavras, repetidas uma e outra vez, sobre a importância dos professores nos "desafios do futuro". Ou porque lhes cabe formar os recursos humanos necessários ao desenvolvimento econômico, ou porque lhes compete formar as gerações do século XXI, ou porque devem preparar os jovens para a sociedade da informação e da globalização, ou por qualquer outra razão, os professores voltam a estar no centro das preocupações políticas e sociais.
\end{abstract}

A melhoria da educação brasileira vincula-se à reconstrução e à afirmação da identidade profissional dos professores, o que necessita fundamentálos em conhecimento sobre seu papel e funções na sociedade. É preciso resgatar a figura do professor e colocá-lo em evidência, o que é compartilhado também com 
Nóvoa (1999, p. 4) que revela este ângulo das capacitações:

\begin{abstract}
É nestes textos que se cunha o conceito de centralidade dos professores. No relatório da OCDE 6,Education Policy Analysis (1998), em apenas três páginas, utilizam-se expressões como: "trazer outra vez os professores para o retrato"; "colocar os professores no centro dos processos sociais e econômicos"; "os professores são os profissionais mais relevantes na construção da sociedade do futuro"; "os professores têm de voltar para o centro das estratégias culturais"; "os professores estão no coração das mudanças". Tudo isto para concluir que "a centralidade dos professores nem sempre é devidamente reconhecida no plano político.
\end{abstract}

Mas outro ângulo é percebido por Nóvoa (1999, p.5):

Nos Estados Unidos, um dos grupos que mais têm influenciado as políticas educativas nas últimas décadas, o Holmes Group, escreve na abertura do seu relatório Tomorrow's Schools of Education: "Muitas pessoas e instituições dedicam-se à formação de professores, apenas e unicamente por se tratar de um mercado rentável. A formação de professores e de educadores é um grande negócio numa nação que emprega mais de três milhões de educadores. Os dólares cintilam nos olhos daqueles que andam à procura de boas oportunidades de mercado.

Este aspecto chama a atenção porque é comum empresas privadas divulgarem cursos para formação continuada aos professores sem, contudo, conter embasamentos teóricos ou, muitas vezes elaborados por leigos.

Dessa forma, cabe ao professor gerenciar sua profissionalização ou sua auto - formação. Querem-se alunos críticos, reflexivos e transformadores, o professor também necessita desses atributos, monitorando e fortalecendo a conexão entre seu desenvolvimento e o dos alunos. O professor assim como outros profissionais precisa também construir seu processo de aprendizagem e transformar-se constantemente, porque as informações com a globalização ocorrem rapidamente.

${ }^{6}$ A Organização para Cooperação e Desenvolvimento Econômico - OCDE é uma organização internacional e inter-governamental que reúne os países mais industrializados. Por meio a $\underline{\mathrm{OCDE}}$, os representantes se reúnem para trocar informações e alinhar políticas com o objetivo de potencializar seu crescimento econômico e colaborar com o desenvolvimento de todos os demais países membros. 
Assim a formação do professor, de acordo com Fusari (1988) e Pimenta (2002) é um processo continuum, que está em constante construção, desconstrução e reconstrução de conceitos.

O educador necessita reformular as questões pedagógicas, e centrar sua atuação na compreensão dos processos que o aprendiz elabora para aprender. Com essa visão, a formação contínua deveria levar esses princípios à prática e desenvolver nova postura para que o educador não seja um simples transmissor de conhecimento; mas sim elaborador de estratégias para o aluno construir seus conhecimentos com base em experiências que provoquem conflitos cognitivos para que novos conhecimentos sejam produzidos e internalizados, e assim também aprenda a aprender.

A nova concepção exige do profissional uma mudança de postura frente ao processo ensino e aprendizagem e para uma prática inovadora se faz necessária aquisição de novas competências.

Perrenoud (2000, p. 26) apresenta dez novas competências para ensinar, sendo elas: "Organizar e dirigir situações de aprendizagens; Administrar a progressão das aprendizagens; Conceber e fazer evoluir os dispositivos de diferenciação; Envolver os alunos em suas aprendizagens e em seu trabalho; Trabalhar em equipe; Participar da administração da escola; Informar e envolver os pais; Utilizar novas tecnologias; Enfrentar os deveres e os dilemas éticos da profissão; Administrar sua própria formação contínua".

Essas competências, todas de suma importância para o crescimento profissional, são interligadas e desencadeiam todas as outras, porque, de acordo com Perrenoud, antes de organizar e dirigir situações de aprendizagens, é necessário que o professor seja capaz de identificar e de valorizar suas próprias competências, dentro de sua profissão e da prática social.

Com a globalização e o avanço tecnológico exigem - se mudanças, adaptações, atualização e aperfeiçoamento. Quem não se atualiza fica para trás. A concepção moderna de educador exige "uma sólida formação científica, técnica; e política, viabilizadora de uma prática pedagógica crítica e consciente da necessidade de mudanças na sociedade brasileira" (BRZEZINSKI, 1994, p.83).

Isso nos coloca a refletir que o profissional consciente sabe que sua 
formação não termina na universidade. Muitos professores, mesmo tendo sido assíduos, estudiosos e brilhantes, aprendem na prática. Daí a necessidade de estudar, pesquisar, observar constantemente.

É preciso disponibilizar os saberes discutidos nas Universidades e Academias, nos cursos que envolvam a formação de professores, visto que a sala é o local privilegiado, onde ocorre a formação dos alunos e se garante a democracia do ensino.

Ao educador compete propiciar melhor desenvolvimento das habilidades, competências e atitudes dos educandos para promover ensino de qualidade e nas palavras de Nóvoa (1992, p.9) "Não há ensino de qualidade, nem reforma educativa, nem inovação pedagógica, sem uma adequada formação de professores" e a formação continuada torna-se necessária para aprimoramento dos educadores.

Para Cró (1998), na formação de educadores, os programas ou cursos precisam ser elaborados de modo a contemplar a inter e a transdisciplinaridade, porque de acordo com a autora, o que não se experiência, não se reproduz. $\mathrm{Na}$ formação dos educadores, em algumas vezes, o modelo de trabalho ou de atividades é desconexo, sem relação interdisciplinar, por isso os professores têm dificuldades de perceber a interdisciplinaridade, e, sem essa percepção, sua prática pedagógica ficará falha, necessitando de novas intervenções.

Inúmeras vezes, os educadores não têm claro as definições das terminologias, como, por exemplo: multidisciplinar que, de acordo com Cró (1998), consiste na soma de disciplinas ideais; pluridisciplinar, definido como várias disciplinas em relação com o projeto de formação; interdisciplinar que agrega as diferentes disciplinas em torno de um problema, ou seja, vários especialistas das diversas disciplinas em torno de um problema; transdisciplinar que consiste em partir de uma noção ou de um projeto e contemplá-lo por meio de um conjunto de disciplinas do currículo de formação.

Essa formação contínua buscou trazer para o centro da reflexão a questão curricular das escolas que, muitas vezes, trabalham com disciplinas desarticuladas, fragmentadas ou deixam de trabalhar com projetos que associam disciplinas afins. 
Assim alguns projetos de formação continuada objetivam demonstrar aos educadores como trabalhar interdisciplinarmente, como é o caso do Programa Ensino Médio em Rede.

Na formação continuada, o professor também precisa ter como modelo aulas ou experiências educativas e uma formação interdisciplinar, para que possa reproduzir ou refletir sobre essa necessidade, porque não se aprende primeiramente Geografia, para depois se localizar no tempo e no espaço. Isso acontece concomitantemente, ou seja, as atividades diárias do cotidiano são interdisciplinares. As disciplinas surgiram para explicar o contexto e isso o professor precisa ter bem claro em sua prática pedagógica. Os assuntos ou conteúdos a serem abordados não podem ser estanques ou desvinculados de sentido.

Assim, a formação contínua, no Programa Ensino Médio em Rede objetivou também a mudança de paradigma dos educadores para melhor conceituar cada disciplina.

A formação continuada em serviço contribui para que os educadores tivessem novas concepções ${ }^{7}$ sobre determinados assuntos ou posturas relacionadas ao aluno e ou metodologia para ensinar e aprender. No final do Século XX, a sociedade passou por transformações radicais, em todos os setores, em decorrência do avanço da tecnologia. Todas as atividades humanas sofreram mudanças havendo progressos num movimento de circularidade e espiral.

A escola percebe essa mudança, mas ainda está caminhando lentamente para as evoluções.

As capacitações em serviço deveriam contribuir para mudança de paradigma, ou de concepções, aqui entendida como descreve Cró (1998, p.93) "Representações e concepções fazem parte das construções mentais mobilizadas pelos indivíduos para aprender, para compreender uma situação, resolver um problema", enfrentando os desafios de promover o avanço. Para tanto a postura dos professores frente a essa nova dimensão, há de ser de rompimento de antigas crenças e senso comum para novas abordagens.

$\mathrm{Na}$ formação contínua de professores, há também entrelaçada a concepção que os organizadores das capacitações e cursos têm sobre a forma com que ocorre a aprendizagem dos professores. Abordaremos, rapidamente, as descritas 
por Cró (1998, p. 93), que julgamos ser a abordagem instituída no desenvolvimento do Programa, como a:

${ }^{7}$ Faculdade de perceber, ou seja,a forma como se percebe o desenvolvimento do Programa.

abordagem objectivista que reflectiria a posição tomada por aqueles que como Varela (1989) chamam os cognitivistas de $2^{\mathrm{a}}$ geração, que definem a cognição como a computação de representações simbólicas;

abordagem construtivista que considera a concepção da aprendizagem como um tipo de conhecimento ingênuo e individual construído na interação do sujeito com o meio. A construção depende, portanto do meio no qual o sujeito se encontra, mas também do próprio sujeito, da sua história, do seu projeto.

A abordagem objetivista se interessa pelo ponto de vista do indivíduo sobre a sua própria experiência. A abordagem construtivista tem o sujeito como processo que interage e tem a sua própria história, o que reforça Cró (1998, p. 80):

$\mathrm{Na}$ construção de uma concepção de aprendizagem por um sujeito que intervêm elementos do meio, as concepções construídas por ele anteriormente, os acontecimentos vividos, as interacções significativas com os colegas, as representações das situações desejadas e a sua própria história como pessoa.

Assim, de acordo com a maneira como os organizadores percebem a aprendizagem, são formulados os cursos, palestras, projetos que visam à formação continuada. Nesse Programa de formação continuada, Ensino Médio em Rede, pareceu-nos que lançaram mão da perspectiva construtivista, colaborando para que os professores depois de refletirem sobre o embasamento teórico, construíssem seus planos de aulas interdisciplinarmente.

Por outro lado, nos diz Cró (1998, p. 82)

... no professor uma orientação externa poderia ter origem no recalcamento ligado a uma autoridade inibidora. $O$ professor não encontraria nele próprio as fontes dos seus conhecimentos, mas pelo que Ihe é oferecido por uma autoridade exterior.

Um dos objetivos da formação continuada fortalecer as equipes escolares para dar suporte a mudanças na prática pedagógica, tem implícito a mudança de paradigma dos professores, porém essas mudanças são percebidas ao longo de 
muitos anos.

Um programa ou curso que tem como pretensão a mudança de paradigma, não colheria seus frutos em pouco tempo.

\title{
2.3 Mudança de paradigma
}

\begin{abstract}
"Mentores e implementadores de programas ou cursos de formação continuada, que visam a mudanças em cognições e práticas, têm a concepção de que, oferecendo conteúdos e trabalhando a racionalidade dos profissionais, produzirão a partir do domínio de novos conhecimentos mudanças em posturas e formas de agir". (GATTI, 2003, p. 5).
\end{abstract}

Alguns cursos ou formação continuada têm como pretensão a mudança da prática ou forma de agir. A concepção de formação continuada para a mudança de paradigma é muito limitada. Gatti (2003, p.5), ao pesquisar o assunto, nos aponta que:

\begin{abstract}
Essa concepção é muito limitada e não corresponde ao que ocorre nesses processos formativos. Os conhecimentos são incorporados ou não, em função de complexos processos não apenas cognitivos, mas socioafetivo e culturais. Essa é uma das razões pelas quais tantos programas que visam a mudanças cognitivas, de práticas, de posturas, mostram-se inefetivos.
\end{abstract}

Ao colocar em pauta o termo mudança de paradigma, importante ressaltar que nos últimos anos esse termo está comumente utilizado nas publicações que versam sobre formação em serviço, porém nem todos os cursos ou programas têm esse objetivo. Refletindo sobre, encontramos que o termo "mudança de paradigma" foi cunhado por Thomas Kuhn, em seu livro The Structure of Scientific Revolutions, publicado em 1962; e, de acordo com Marilyn Ferguson (1980, p.26), as idéias de Kuhn "aumentam a compreensão do surgimento de novas perspectivas e analisam as causas da resistência às novas mudanças sistêmicas". A própria Marilyn Ferguson (op.cit, p.26) então descreve a definição de Kuhn da palavra "paradigma" da seguinte maneira:

Uma estrutura de pensamento ("do grego paradigma, padrão"). Um paradigma é um esquema para a compreensão e explicação de certos aspectos da realidade... "uma mudança de paradigma" é um modo completamente novo de pensar sobre antigos problemas. 
Zeichener (1983, p.3) define paradigma como "uma matriz de crenças e suposições sobre a natureza e os propósitos da escola, do ensino e da sua formação, que configuram um conjunto de características específicas na formação de professores".

termo também vem sendo utilizado em todos os setores da sociedade como no meio empresarial, referindo - se às inovações.

Em seu artigo, Corbett (1997, p.3) faz referência a alguns autores que definem o termo mudança de paradigma e que vale a pena ressaltar:

Para Adam Smith, paradigma consiste em: "Suposições compartilhadas. 0 paradigma é a forma como nós percebemos o mundo; água para os peixes. O paradigma explica o mundo para nós e nos ajuda a prever o seu comportamento".

Para Barker, paradigma é: "um conjunto de regras e regulamentos (escritas ou não) que faz duas coisas: (1) estabelece ou define limites; (2) diz como devemos comportar dentro desses limites para sermos bem sucedidos".

Assim, as capacitações em serviço que visam à mudança de paradigma, objetivam a mudança conceitual para que a prática seja transformada, o que é confirmado por Nóvoa apud Vasconcelos (2000, p.48), "Como toda formação encerra um projeto de ação e de transformação e não há projeto de ação e de transformação sem opções".

Saindo um pouco da área educacional e tomando como exemplo o setor privado industrial, as empresas que operam na área de telefonia entendem bem a que se refere o termo "mudança de paradigma".Com a criação do telefone celular a mudança de paradigma ocorre constantemente, e essas mesmas empresas vão aperfeiçoando-se, adaptando-se constantemente.Haja vista que os primeiros celulares "apenas eram móveis" e, atualmente, executam operações bancárias, registram momentos através de fotos e filmagens.

Nesse sentido, é que evoco a mudança da prática pedagógica educacional, em que seus profissionais seriam chamados para saírem da situação de acomodação e repensarem a prática, para avançarem, porque os alunos têm necessidade de mudança, necessidade de evolução. As crianças são curiosas por natureza e os jovens anseiam por novidades.

Se a prática educativa não apresentar inovações, com aulas significativas, na qual se trabalha a partir do contexto do aluno, perde o sentido, 
e deixa de motivar. O aluno, motivado produz, e é chamado a produzir a partir de situações-problema, porque sente necessidade e apresenta desejo em aprender e vê relação entre os conhecimentos produzidos na escola e a realidade.

Porém a mudança de paradigma não se percebe de imediato. Acontece de forma lenta e gradativa, num processo contínuo.

Quando se observa a participação de professores em capacitações contínuas, e considerando sua fala, obtêm-se relatos como este:

Confesso que fico um pouco insegura ainda quanto à forma de aplicar essas novas metodologias, porém, não será possível continuar como estava fazendo. Talvez, faça essas mudanças aos poucos. Me preocupo com o currículo e com o conteúdo específico. Preciso refletir muito sobre isso"( professor $n^{\circ} 1$, participante do programa Ensino Médio em Rede).

Essa fala representa o compromisso do professor, sua busca de novos conhecimentos, que poderá gerar mudança da prática. Quando uma informação gera a desestabilização, gera aprendizagem e poderá haver mudança de conceitos, ou seja mudança de paradigma. Esse professor que refletiu sobre a prática, através da capacitação, não será mais o mesmo. Algo mudou. Mesmo que demande um pouco de tempo, a mudança ocorrerá. 


\section{ENSINO MÉDIO EM REDE: UM PROGRAMA DE FORMAÇÃO CONTINUADA}

Art. $1^{\circ}$. A educação abrange os processos formativos que se desenvolvem na vida familiar, na convivência humana, no trabalho, nas instituições de ensino e pesquisa, nos movimentos sociais e organizações da sociedade civil e nas manifestações culturais.LDB, 9394/96.

O Programa Ensino Médio em Rede, voltado especificamente para os professores que atuam no Ensino Médio, constituiu-se num dos Programas de Formação Continuada proposto pela Secretaria de Educação do Estado de São Paulo, a partir da Coordenadoria de Estudos e Normas Pedagógicas (CENP). Esse programa de formação continuada pretendeu capacitar os assistentes técnicopedagógicos, professores - coordenadores e professores de todas as escolas estaduais, tendo como principal objetivo orientar professores e planejar propostas de intervenção interdisciplinar, tendo em vista o planejamento escolar, sobretudo no que diz respeito ao trabalho com compreensão e produção de textos e o incentivo à leitura.

O Programa foi idealizado para ser desenvolvido ao longo do ano letivo de 2004 e se estendeu até 2006, e mesclou formação em serviço dos professores e formação de agentes multiplicadores, buscando formar os Assistentes Técnicos Pedagógicos - ATP - das Diretorias de Ensino.

Para essa formação foram previstas três grandes ações articuladas: formação dos professores de Ensino Médio (sob a responsabilidade direta dos * PC e dos ** ATP), formação dos professores - coordenadores (sob a responsabilidade da CENP/Coordenação do Ensino Médio, da equipe de especialistas e dos ATP) e formação dos ATP (sob a responsabilidade da CENP/Coordenação do Ensino Médio e da equipe de especialistas).

* PC - professor - coordenador

${ }^{*}$ ATP - Assistente Técnico Pedagógico da Diretoria de Ensino 
O esquema seguinte ilustra a dinâmica dessas ações de formação.

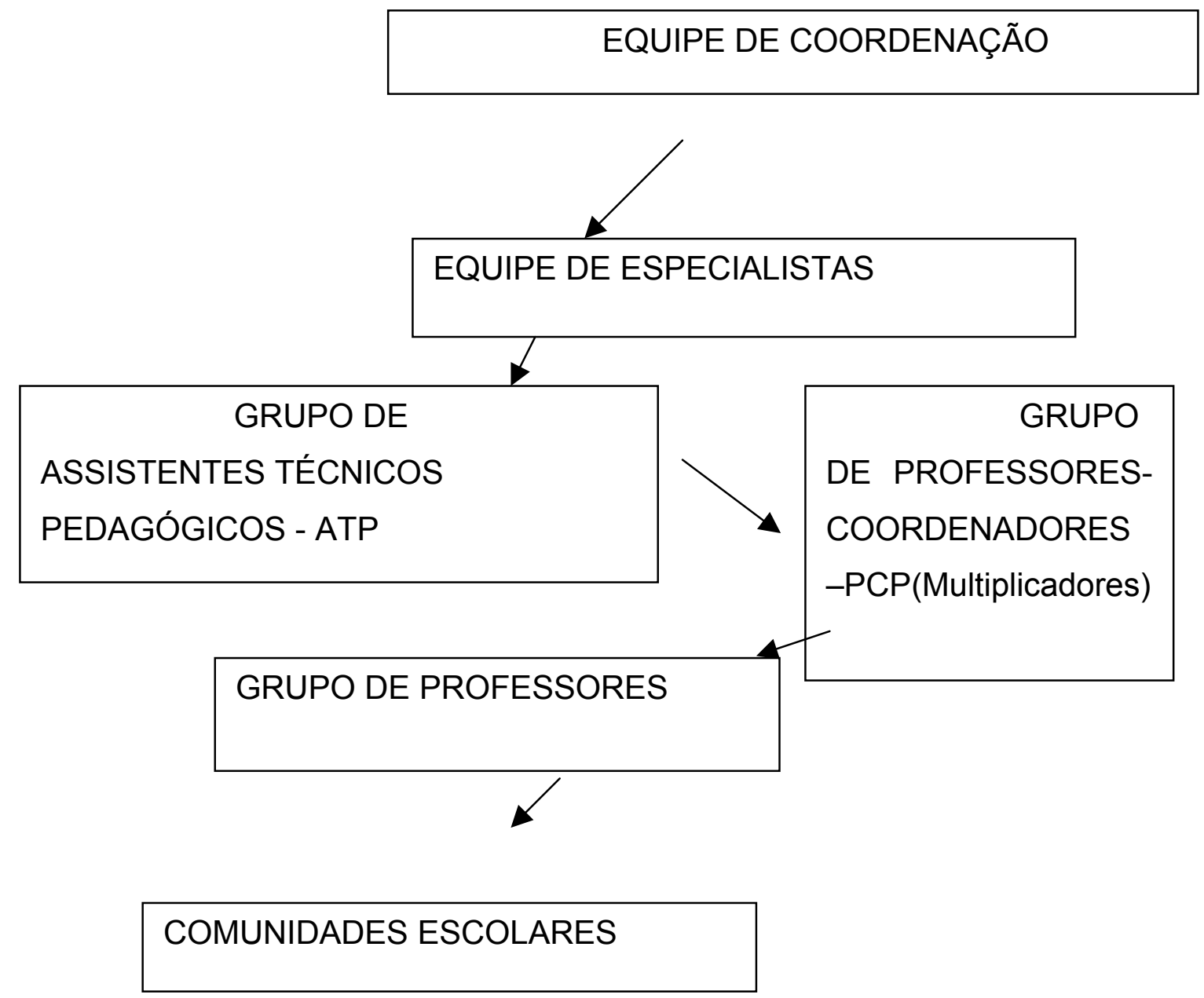

O Programa enfatizou o trabalho com a leitura e a escrita, o aperfeiçoamento do processo de gestão escolar e ampliação e ou adequação dos espaços pedagógicos da escola.

Esteve formatado para trabalhar quatro temas distintos:

Tema 1 - A formação do professor no programa ensino Médio em Rede,trabalhado em 2004.

Tema 2 - Professores e alunos: um encontro possível e necessário, trabalhado em 2005.

Tema 3 - O currículo da escola média trabalhado em 2006.

Tema 4 - O projeto político-pedagógico da escola. 
Para aprofundar os conhecimentos dos professores, o Programa organizou seu desenvolvimento em Vivências,chamadas de Vivências Formativas que subsidiaram o diagnóstico e análise da ação educativa, focalizando aspectos relativos à proficiência leitora e escritora do aluno. Essa vivência foi programada para aprofundar os conhecimentos sobre o currículo e analisar as práticas docentes, de acordo com as orientações iniciais dos organizadores do Programa (CENP,2004, p.7). As Vivências Educadoras possibilitaram a elaboração de projeto de trabalho em sala de aula, sob a orientação do professor - coordenador, ( um professor da escola que ocupa o posto de trabalho de professor-coordenador e que recebia as orientações dos Assistentes técnicos Pedagógicos na Diretoria de Ensino).

As Vivências Formativas foram estruturadas em três seções: Situando a questão, que apresentou o tema a ser debatido e propôs questões para reflexões; Aprofundando a questão, que apresentou roteiros para as discussões sobre os textos e vídeos e atividades de reflexão sobre a prática pedagógica; Sintetizando as idéias propôs atividades que retomaram as discussões, encaminhando para propostas e novas problematizações.

O desenvolvimento das atividades foi projetado para ser trabalhado em três tipos de situações: TRC_ Trabalho Coletivo, que se realizou nos horários de HTPC _ Horas de Trabalho Pedagógico Coletivo que está previsto no Calendário da escola,; TRP, _ Trabalho Pessoal, realizado pelos participantes em horário por eles determinados e TRA _ Trabalho em Sala de Aula, momento de colocarem em prática o projeto elaborado e orientado pelo professor-coordenador da própria escola.

Os conteúdos abordados perpassaram pela visão histórica e as perspectivas atuais do Ensino Médio, com foco nas mudanças exigidas pela sociedade atual, visando à formação cidadã e prosseguimento do ensino, atendendo as deliberações da Lei de Diretrizes e Bases da Educação Nacional, LDB 9394/96.

O Programa buscou chamar a atenção dos professores para que percebessem que as disciplinas são relacionadas entre si, propondo assim a elaboração de projetos que contemplassem a articulação entre as disciplinas de uma mesma área de conhecimento, buscando formas integradoras de tratamento e estudos de diferentes áreas de conhecimento, abrindo-se a possibilidade de 
relacionar as disciplinas em atividades de projeto e pesquisa, por meio da interdisciplinaridade e contextualização como princípios.

Utilizou como metodologia a forma coletiva de trabalho, desenvolvido nos Horários de Trabalho Pedagógico Coletivo - HTPCs, oportunizando momentos para que os professores construíssem aulas para serem aplicadas nas salas de aula,em grupo e coletivamente.

O professor - coordenador pedagógico foi o responsável pela modalidade de Trabalho Coletivo (TRC), realizado nas unidades.

Como modalidades, integrando a metodologia de trabalho, encontraram-se:

TRP (Trabalho Pessoal) - Trabalho individual realizado em local e horário de livre escolha, fora do horário de trabalho, cujas produções foram orientadas pelos formadores e entregues aos mesmos;

TRS (Trabalho na Rede do Saber) - Trabalho realizado presencialmente nos ambientes da Rede do Saber ( ambiente via Internet que possibilita disponibilizar textos, artigos, resoluções e espaços para registros) antes, durante e depois de uma videoconferência,'sob a responsabilidade dos mediadores;

TSA (Trabalho na Sala de Aula) - Trabalho presencial em sala de aula no qual os professores realizaram com seus alunos as atividades previstas no Programa;

WEB (Trabalho via internet) - Em ambiente virtual de colaboração, realizado pelos mediadores e professores coordenadores, sob orientação de seus responsáveis pela formação; professores representantes de área também participaram das atividades web. Esses professores foram escolhidos pelo professor-coordenador, de acordo com um perfil, cujo critério estabeleceu facilidade de coordenar um subgrupo, facilidade de repassar informações e conhecimentos básicos de informática.

VC $^{8}$ (Videoconferência) - Realizada nos ambientes da Rede do Saber, coordenada por especialistas; houve vídeo conferências, específicas para mediadores (Assistentes Técnicos Pedagógico da Diretoria de Ensino); outras que foram comuns a mediadores e professores - coordenadores e ainda outras que foram comuns a mediadores e professores representantes de área;

TC $^{9}$ (Teleconferência) - Destinada a todos os participantes envolvidos no Programa; realizada por especialistas convidados. 
A organização, o Regimento Interno, as funções de cada grupo encontraram-se disponíveis em site específico (www.rededosaber.sp.gov.br) para orientar os participantes.

A proposição desse programa se justifica considerando-o que segue abaixo:

Em primeiro lugar, cabe considerar que a recente ampliação de ofertas de vagas para o Ensino Médio e a melhoria da qualidade do Ensino Fundamental, que resultou na queda dos índices de repetência e abandono, são responsáveis por um aumento significativo da procura por este nível de ensino. De fato, como aponta o Censo Escolar de 2002, no Estado de São Paulo, houve uma significativa expansão de ofertas de vagas e conseqüente crescimento de matrículas no Ensino Médio, fenômeno que, nesse caso, pode ser explicado como decorrente da implantação da progressão continuada, da correção do fluxo e de outros fatores sociais e econômicos que facilitam o acesso dos jovens à escola média.

Outro fator a ser levado em conta são as novas exigências do mundo do trabalho, que trazem de volta à escola um contingente populacional dela afastado. A chegada de mais adolescentes ao Ensino Médio, a incorporação de grupos sociais antes excluídos da continuidade de estudos e o retorno dos que haviam deixado a escola criam um quadro de explosão da demanda e de grande diferenciação da clientela.

Além disso, conforme apontam os Parâmetros Curriculares Nacionais Ensino Médio 1, é urgente repensar as diretrizes gerais que orientam esse nível de ensino, levando-se ainda em conta outros fatores. Em primeiro lugar, a ruptura tecnológica, característica da chamada terceira revolução técnico-industrial que, a partir da década de 80 , se acentua no País e que promove mudanças radicais na área do conhecimento, passa a ocupar um lugar central nos processos de desenvolvimento em geral.

"É possível afirmar que, nas próximas décadas, a educação vá se transformar mais rapidamente do que em muitas outras, em função de uma nova compreensão teórica sobre o papel da escola, estimulada pela incorporação das novas tecnologias".

Disponível em :www.rededosaber.sp.gov.br/emrede

Este programa procurou estabelecer interlocução com todos os educadores que atuam nas escolas de Ensino Médio da rede pública estadual das diferentes regiões do Estado de São Paulo.

\footnotetext{
\& Na Secretaria de Estado da Educação no Estado de São Paulo há mecanismos - Rede do Saberque possibilita a comunicação entre diferentes locais, possibilitando videoconferência que permite a discussão e comunicação em tempo real,em grupo na qual os participantes estão em locais diferentes, mas podem ver e ouvir uns aos outros como se estivessem reunidos em um único local .Esse sistema interpessoal de videoconferência possibilita a comunicação em tempo real entre grupos de pessoas, independente de suas localizações geográficas, em áudio e vídeo simultaneamente. Esse sistema possibilita que se trabalhe de forma cooperativa, compartilhando informações e materiais de trabalho sem a necessidade de locomoção geográfica.

9 Teleconferência consiste em um serviço que permite a comunicação simultânea para diferentes localidades, com a comodidade de poder realizar reuniões, treinamentos à distância, ou até mesmo palestras, economizando assim tempo e gastos com viagens e hospedagem. A Conferência via web é uma ferramenta que permite a apresentação de arquivos power point e aplicativos em geral, durante a Teleconferência
} 
Estiveram envolvidos Dirigentes da Diretoria de Ensino, Supervisores das Diretorias de Ensino, Assistentes Técnicos Pedagógicos (professores responsáveis por projetos e que dão suporte pedagógico nas Diretorias de Ensino), Diretores, Professores - Coordenadores e Professores que atuam no ensino Médio.

\section{QUADRO 1 - Participantes do Programa Ensino Médio em Rede, na Diretoria de Ensino da Região de Presidente Prudente-2004}

\begin{tabular}{|c|c|}
\hline Educadores que participaram do EMR: & Quantidade de educadores envolvidos \\
\hline $\begin{array}{l}\text { Especialistas formadores-responsáveis } \\
\text { pelo circuito ao qual a Diretoria pertence }\end{array}$ & 02 \\
\hline $\begin{array}{l}\text { Especialistas formadores responsáveis } \\
\text { pelas VC* - as quais se destinam aos } \\
\text { mediadores, aos coordenadores. Aos } \\
\text { professores representantes. }\end{array}$ & 06 \\
\hline $\begin{array}{l}\text { Mediadores }-\mathrm{ATP}^{* *} \text { responsáveis pelo } \\
\text { Programa nas escolas da Diretoria. }\end{array}$ & 05 \\
\hline $\begin{array}{l}\text { Professores coordenadores pedagógicos - } \\
\text { PCP }^{* *} \text { responsáveis pelo desenvolvimento } \\
\text { do Programa nas } 40 \text { escolas envolvidas } \\
\text { nesta Diretoria de Ensino - Multiplicadores }\end{array}$ & 45 \\
\hline $\begin{array}{l}\text { Professores representantes } \mathrm{PR}^{* *} \text { - } \\
\text { responsáveis pelo apoio ao } \mathrm{PCP} \text { e aos } \\
\text { professores no trabalho em áreas nas } \\
\text { escolas. }\end{array}$ & $\begin{array}{c}135 \\
\text { (cada } \mathrm{PCP}^{* *} \text { inscrito conta com auxílio de } 3 \\
\mathrm{PR}^{*} \text { : um de cada área do conhecimento) }\end{array}$ \\
\hline $\begin{array}{l}\text { Professores - os quais participam do } \\
\text { Programa em seus respectivos locais de } \\
\text { trabalho - Unidades Escolares. }\end{array}$ & 514 \\
\hline $\begin{array}{l}\text { Total de educadores envolvidos no } \\
\text { Programa na Diretoria de Ensino ao qual } \\
\text { pertence a escola de realização da } \\
\text { pesquisa }\end{array}$ & 707 \\
\hline
\end{tabular}

Fonte: Diretoria de Ensino da Região de Presidente Prudente 
Siglas utilizadas *VC: Vídeo conferência. ${ }^{* *}$ PCP: Professor Coordenador Pedagógico ; PR: Professor responsável por área; ATP- Assistente Técnico Pedagógico.

As atividades do Programa, no entanto, foram concebidas especificamente para a formação de: nas Diretorias de Ensino: Assistente Técnico Pedagógicos e Supervisores; nas escolas: professores que atuam no ensino médio regular e EJA e professores - coordenadores pedagógicos.

Assim, foram envolvidos, no Estado de São Paulo:

- Todos os professores (efetivos) de Ensino Médio das 3.083 escolas da rede estadual

Professores coordenadores (PC): 6.166 (2 PC por escola)

- Assistentes técnico-pedagógicos (ATP): 332

Interessante ressaltar os dados quantitativos referentes ao Ensino Médio-Programa de Formação Continuada para professores do Ensino Médio, na Diretoria de Ensino da Região de Presidente Prudente, local de realização deste trabalho. O quadro número 1 , aponta os dados relacionados ao Programa. Indica o número de especialistas e professores que atuaram no Programa na Diretoria da Região de Presidente Prudente e dele participaram.

Para entender e analisar os impactos dessa formação, necessário se faz colocar em pauta os objetivos do Programa que propõe desencadear ações no sentido de:

-promover a discussão sobre as especificidades curriculares do Ensino Médio;

-aprofundar a capacidade dos assistentes técnico-pedagógicos e dos professores coordenadores de diagnosticar a realidade escolar, analisar criticamente a proposta pedagógica das escolas, orientar professores e planejar propostas de intervenção, tendo em vista o planejamento escolar, sobretudo no que diz respeito ao trabalho com compreensão e produção de textos;

- propiciar subsídios para que os professores possam diagnosticar a realidade de suas escolas, avaliarem seu projeto político pedagógico e os programas curriculares de áreas, tendo em vista o planejamento escolar, sobretudo no que diz respeito ao trabalho com compreensão e produção de textos;

- desenvolver competências leitoras e escritoras dos agentes educacionais de Ensino Médio e fornecer subsídios para que os professores possam também, desenvolver essas competências em seus alunos.

-promover a integração entre os professores das áreas, a partir de uma perspectiva interdisciplinar de discussão sobre projeto pedagógico;

- fortalecer as equipes escolares para dar suporte a mudanças na prática 
pedagógica;

-possibilitar aos agentes educacionais o conhecimento e a utilização de novas tecnologias de comunicação e informação, através do uso de diversas mídias interativas, discutindo seus usos na continuidade da sua própria formação e na sua prática educativa.

Disponível em: www.rededosaber.sp.gov.br/emrede

\subsection{Operacionalização do Programa}

De acordo com publicação no site: www.rededosaber.sp.gov.br, sobre o formato do programa, em nível de escola, os professores, sob a orientação dos professores coordenadores pedagógicos, realizaram, durante os horários de trabalho pedagógico - HTPC-, a maioria das atividades, enquanto que os professores coordenadores, os assistentes técnico-pedagógicos e os supervisores de ensino desenvolveram as atividades em seus horários de trabalho nas Diretorias de Ensino, nas unidades escolares e nos ambientes da Rede do Saber, sob a orientação da coordenação do programa.

O material foi especialmente elaborado para os participantes e previu diferentes modalidades de atividades para os diferentes agentes educacionais: teleconferências, videoconferências, atividades pela internet e intranet ( Rede do Saber, que disponibiliza informações via web) atividades presenciais, oficinas de leitura e escrita e vivências educadoras.

O Programa utilizou como recurso as teleconferencias como forma de capacitar a distância os multiplicadores, ou seja, os professores-coordenadores que, após as audiências, capacitavam os professores na escola.Esse recurso fica disponível na sala de Conferências na Diretoria de Ensino.

Com o avanço da tecnologia, a videoconferência, segundo Santos (1998, p.3), apresenta uma série de aspectos favoráveis: 
-representa uma economia de recursos, por não haver gastos com viagem, o que implica também em uma maior disponibilidade de horários, na medida em que os equipamentos estão disponíveis e é mais fácil marcar uma reunião num estúdio do que viajar;

-representa um recurso a mais para a pesquisa porque permite a gravação em fita de vídeo, como registro da reunião;

- finalmente, a percepção da interface eletrônica praticamente desaparece depois de alguns minutos já que o manuseio do equipamento é fácil e de rápida aprendizagem.

As videoconferências possibilitaram discussões entre os participantes de diversas regiões, promovendo assim uma integração entre os diversos participantes.

As atividades por meio da Internet serviram para que os professorescoordenadores enviassem relatórios das atividades para a equipe organizadora do Programa, como forma de acompanhamento e registro das atividades desenvolvidas.

Os professores inscritos no programa Ensino Médio em Rede receberam material impresso, ( pasta arquivo que possibilitou o armazenamento de textos e materiais) e CD, contendo a parte teórica para leituras e reflexões.

Esse Programa se propôs a fazer uso dos ambientes de ensino e aprendizagem e as mídias e tecnologias da Rede do Saber - teleconferências, videoconferências e web, além de materiais de apoio (textos jornalísticos e científicos, retirados de jornais ou de revistas especializadas). O professor coordenador enviava, via ferramenta digital - internet, relatórios de análise e síntese dos estudos sobre as áreas estudadas pelos professores, sobre seu campo de atuação e que também realizavam atividades interdisciplinares.

\subsection{O Programa no Ambiente da Pesquisa}

Na Escola Estadual Fernando Costa, o programa se desenvolveu nos anos de 2004, 2005, 2006, com os professores efetivos . Importante ressaltar que na 
escola pública há rotatividade de professores anualmente e em algumas vezes mensalmente. Por essa razão os programas precisam ser retomados ao início de cada ano porque pressupõem o domínio dos conteúdos da fase anterior, e o acesso e domínio devem ficar sob a responsabilidade dos participantes com apoio dos seus formadores locais.

Participaram do desenvolvimento do Programa nesta escola, vinte e dois (22) educadores, porém nem todos se dispuseram a participar da pesquisa, alegando falta de tempo, ou outros motivos particulares. Diante disso, focamos a pesquisa em dez professores e um professor-coordenador

O quadro abaixo, número 2, indica a quantidade de professores que participam do Programa Ensino Médio na Escola Fernando Costa.

QUADRO 2 - Situação funcional dos professores que participam do Programa Ensino Médio em Rede na E.E.Fernando Costa._Ano base 2006.

\begin{tabular}{|c|c|c|c|c|}
\hline \multicolumn{2}{|c|}{ Situação funcional } & \multicolumn{2}{|c|}{ Sexo } & Total de professores \\
\hline Efetivo & OFA $^{*}$ & Masculino & Feminino & \\
\cline { 1 - 3 } 19 & 3 & 5 & 17 & 22 \\
\hline
\end{tabular}

Fonte: Documentos da Escola. Dados trabalhados pelo autor

*OFA_ - Professor contratado: Ocupante de Função Atividade.

Dos professores que atuaram no Ensino Médio, nesta Unidade Escolar, objeto de observação desse trabalho, percebemos que, conforme demonstra o gráfico, no tempo de serviço, há maior índice no tempo de atuação no magistério, e menor índice nesta escola, confirmando a rotatividade de professores na rede pública, o que dificulta a integração, a sintonia de ações e a continuidade dos projetos.

O gráfico abaixo indica o total de professores que atuaram no Ensino Médio, em tempo de serviço no magistério e na unidade escolar. 
GRÁFICO 1 -Tempo de serviço dos professores que atuaram na E.E.Fernando Costa - Ano Base 2006

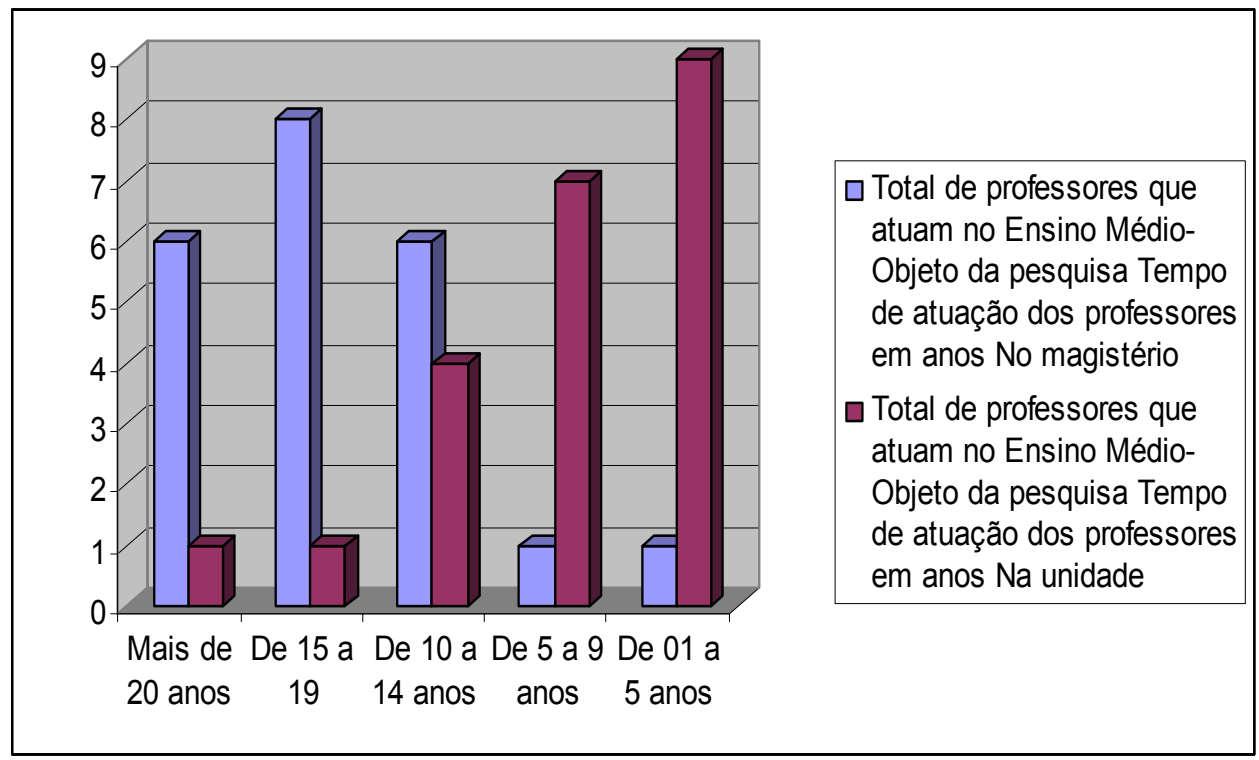

Fonte: Documentos arquivados na E.E.Fernando Costa. Ano base 2006. Dados trabalhados pelo autor.

No magistério, entende-se como tempo trabalhado na educação. $\mathrm{Na}$ Unidade Escolar, entende-se tempo de atuação na escola, foco da pesquisa. 


\section{METODOLOGIA DA PESQUISA}

Na pesquisa qualitativa é importante que a interação com o objeto de estudo permita, não só, o entendimento pelos sujeitos analisados, como também um distanciamento necessário para que todos os elementos surgidos da realidade sejam considerados na pesquisa de forma reflexiva e crítica. Taylor e Bodgan (apud LUDKE; ANDRÉ, 1986, p.20).

O objetivo deste capítulo consiste em descrever todos os passos da pesquisa dentro dos procedimentos metodológicos.

Vale lembrar que segundo Nisbet e Watt (1978), apud Lüdke e André (1988, p.21), este tipo de investigação: estudo de caso é caracterizado por seu desenvolvimento em três fases, "sendo uma primeira aberta ou exploratória, a segunda mais sistemática em termos de coleta de dados e a terceira consistindo na análise e interpretação sistemática dos dados e na elaboração do relatório [...], essas três fases se superpõem em diversos momentos, sendo difícil precisar as linhas que as separam."

Ao iniciar esta pesquisa, foi preciso definir o tipo de pesquisa que seria explorada: qualitativa ou quantitativa. Após investigar as características de cada uma delas optamos pela qualitativa, visto que de acordo com Lima (2001, p.31)

Enquanto os valores individuais, portanto, subjetivos são desprezados na pesquisa quantitativa, que centra sua atenção na objetividade, nos fatos palpáveis, o mesmo não ocorre quando se trata da pesquisa qualitativa.

Promovendo breve comparação percebemos que Haguette (1990, p.55) nos aponta que:

...os métodos quantitativos supõem uma população de objetos de observação comparável entre si e os métodos qualitativos enfatizam as especificidades de um fenômeno em termos de suas origens e de sua razão de ser.

Numa retrospectiva sobre as origens histórico-filosóficas da 
metodologia qualitativa, verifica-se que Patton, Erickson, Taylor e Bogdan (apud Ludke e André,1988) discordam em alguns pontos, mas situam os primeiros trabalhos de cunho qualitativo entre o final do século $\mathrm{XIX}$ e o início do século $\mathrm{XX}$, com pesquisas sociológicas e antropológicas.

De acordo com Taylor e Bogdan (apud LUDKE; ANDRÉ,1988, p.20), a expressão metodologia qualitativa que se refere "à investigação que produz dados descritivos: as próprias palavras das pessoas, faladas ou escritas e a conduta observável".

A Pesquisa foi desenvolvida seguindo as características da abordagem qualitativa que Taylor e Bogdan (apud LUDKE; ANDRÉ, 1986, p.20) orientam:

a) a abordagem indutiva - $O$ pesquisador qualitativo não tem um modelo préestabelecido que possa ser testado com os dados obtidos. As categorias de análise surgem das observações feitas, na medida em que o investigador tenta entender os padrões de organização que existem;

b) a perspectiva holística - O pesquisador qualitativo parte do todo para as partes, sem a preocupação de quantificar informações e reduzi-las a variáveis;

c) a investigação naturalística - O pesquisador qualitativo é perceptível ao efeito que pode causar sobre os pesquisados e procura intervir o mínimo possível. Em uma entrevista, procura-se deixar os assuntos fluírem naturalmente, como em uma conversação informal, reduzindo ao máximo as perguntas e aceitando os desvios do tema, por saber que toda expressão de idéias traz associações que podem auxiliar na interpretação.

Na pesquisa qualitativa, ressalta-se, como característica, que não há necessidade de grande número de participantes, uma vez que, nessa modalidade de pesquisa, a opção é pela profundidade em detrimento da quantificação.

Essa pesquisa compreende a análise documental que compõe: material disponível no site da educação que explicita os objetivos, metas, cronograma, material disponibilizado aos professores que dá suporte ao projeto, material produzido pelos próprios professores e observação do processo, no 
decorrer de algumas capacitações.

Outro fator na pesquisa qualitativa é que os valores e interesses moldam a visão da realidade, e tem como principal instrumento, ou seja, a entrevista interativa. Berg e Smith (1988) afirmam que a relação possui tanto conseqüências emocionais quanto intelectuais, em ambos os lados. Nas entrevistas objetivamos explorar os pontos de vista em relação ao projeto, ao seu percurso, suas expectativas, dificuldades e facilidades.

A matéria prima para essa exploração qualitativa são os significados das linguagens e o mundo social, as práticas sociais, os valores, que se expressam pela linguagem comum e na vida diária. Dessa forma procuramos canalizar a atenção na interpretação que os próprios participantes têm das situação sob estudo.

No desenvolvimento da pesquisa, tomamos como referencial as orientações de Bogdan e Biklen (1994, p.47), quando dizem que a investigação qualitativa possui cinco características:

1-a fonte direta de dados é o ambiente natural, no qual o investigador é o instrumento principal. Utilizando inúmeras vezes um bloco de papel para anotações, porque o contato direto é o mais utilizado. O investigador qualitativo preocupa-se com o contexto.

2- A investigação qualitativa é descritiva. A coleta de dados consiste em palavras, relatos, imagens, transcrições de entrevistas, notas de campo, fotografias, vídeos, documentos pessoais, memorandos e outros registros, e não em números. A abordagem ocorre de forma minuciosa. Nesta pesquisa analisamos documentos, participamos das reuniões observando as reflexões dos professores, entrevistamos os professores - colaboradores e dialogamos com o professor-coordenador.

3- Os investigadores qualitativos interessam-se mais pelo processo do que pelos resultados ou produtos. $\mathrm{Na}$ pesquisa, procuramos observar a trajetória dos professores durante o desenvolvimento do Programa.

4- Os pesquisadores qualitativos analisam os dados de forma indutiva. "O processo de análise dos dados é como um funil: as coisas estão abertas de início (ou no topo) e vão se tornando mais fechadas e específicas no extremo" (Bogdan e Biklen, 1994,p. 50).

5- O significado é de importância vital. "Analisam quais as conjecturas que as 
pessoas fazem sobre suas vidas" (BOGDAN; BIKLEN,1994, p. 50).

Assim, a pesquisa convergiu para um estudo de caso, visto que envolveu o estudo da aplicação de um Programa da Rede Pública de Ensino do Estado de São Paulo, podendo ser sintetizado como um processo que procura descrever e analisar a formação continuada em termos qualitativos, complexos e compreensivos, com o objetivo de chegar ao conhecimento do objeto estudado, ou seja, o projeto Ensino Médio em Rede e o impacto na prática educativa.

Para Chizzotti (1995, p. 102), o estudo de caso:

(...) é uma caracterização abrangente para designar uma diversidade de pesquisas que coletam e registram dados de um caso particular ou de vários casos (...) o caso é tomado como unidade significativa do todo, e, por isso, suficiente tanto para fundamentar um julgamento fidedigno quanto propor uma intervenção.

Em Triviños (1995, p. 133), esse procedimento:

é uma categoria de pesquisa cujo objeto é uma unidade que se analisa aprofundadamente. A complexidade do estudo de caso qualitativo está determinada pelos suportes teóricos que servem de orientação em seu trabalho de investigador.

Ludke e André (1996, p. 18), indicam como principais características do estudo de caso:

- a visão a descoberta de peculiaridades. Assim, o quadro teórico inicial serve de estrutura básica a fim de que novos elementos ou dimensões sejam acrescentados;

- enfatizam a "interpretação em contexto";

- buscam retratar a realidade de forma completa e profunda;

- usam uma variedade de fontes de informação;

- procuram representar os diferentes e, às vezes, conflitantes pontos de vista presentes numa situação social;

-e os relatos de um estudo de caso utilizam linguagem e forma mais acessível do que os outros relatórios de pesquisa. 
Reforçando a necessidade de abordagem como estudo de caso, percebemos, em Yin (2001, p. 23), que o estudo de caso é a abordagem mais adequada quando o fenômeno de interesse não pode ser estudado fora do seu ambiente natural, como é o foco da presente pesquisa.

Essa pesquisa possibilitou, ao mesmo tempo, analisar as reflexões realizadas nos encontros com os capacitadores, tentando verificar se, independentemente do que foi pretendido no objetivo da formação continuada, elas foram significativas para os professores.

Neste trabalho, não temos uma "população de observação comparável", porque cada professor tem uma filosofia particular sobre o Ensino Médio que norteia sua prática. As especificidades de cada um, em termos de concepções, crenças e práticas docentes, devem ser salientadas e analisadas para detectar as possíveis interações entre essas concepções e crenças e as ações desenvolvidas em seu trabalho docente.

Em se tratando de um estudo de caso, o trabalho se desenvolveu junto à Diretoria de Ensino de Presidente Prudente, Estado de São Paulo, na Escola Estadual Fernando Costa.

Observamos dez educadores que se colocaram à disposição da pesquisa e que estavam participando do Projeto Ensino Médio em Rede.

Os instrumentos de investigação utilizados na presente pesquisa tiveram como base o enfoque interpretativo na abordagem do tema, sendo utilizado questionário semi-estruturado, entrevista com o professor coordenador da Escola Estadual Fernando Costa e professores envolvidos no projeto.

Assim, neste trabalho, os dados foram utilizados com as informações que se pôde obter, através das respostas aos questionários, dos depoimentos dos professores, e nas sínteses do professor-coordenador ( QUADROS 8,9,10,11,12 e 13, em Anexo).

A escolha e elaboração dos instrumentos, adotados na pesquisa, foram baseadas nas idéias apresentadas no referencial teórico e nas implicações que tais idéias têm, em termos de práticas docentes, buscando as concepções dos professores que estavam envolvidos com o projeto e suas perspectivas em relação ao programa. 


\subsection{A Contextualização do Ambiente : a Instituição Educacional}

Consideramos importante situar o leitor no palco em que esta pesquisa aconteceu, ou seja, tecer alguns comentários sobre a instituição escolar onde o projeto se desenvolveu. Em 1939, a cidade de Presidente Prudente estava em amplo progresso e sua população reivindicava a criação de um estabelecimento de ensino médio oficial. Um grupo se mobilizou para tratar da construção do prédio e a cidade que possuía 23 anos de idade e despontava como a mais importante da alta Sorocabana, criou uma comissão para arrecadar fundos para a construção da escola. Assim, conforme Ata: "Aos 29 de outubro de 1939, no paço municipal de Presidente Prudente, tendo comparecido as pessoas que a esta assinam, foi organizada a mesa,..." Assim a comissão iniciou a construção da escola mais tradicional da região do oeste paulista.

De acordo com Ribeiro (1999, p.99):

... a população prudentina inspirada no Manifesto dos Pioneiros, que na época pregava que a educação não deveria ser para poucos, finalmente acordou. Começou a reivindicar um ginásio público gratuito, para aqueles que não podiam pagar um particular.

As reivindicações levadas ao interventor Federal, Ademar de Barros, pelo prefeito municipal Domingos Leonardo Cerávolo foram concretizadas e em 1941, pelo Decreto lei no. 11.864, no dia 23 de abril de 1941. O Ginásio do Estado foi oficialmente instalado na Avenida Antonio Prado, hoje denominada Avenida Washington Luiz, numa área total de terreno de $680 \mathrm{~m}$, que foi adquirida por doação da prefeitura municipal pela Lei $n^{\circ}$. 2032 de 24/12/1952.

Em Ribeiro (1999, p.98), consta que "A vida educacional e cultural desta época caracteriza-se pela pluralidade e confusão de doutrinas que recebiam a denominação comum de Escola Nova".

O alto padrão do ensino da escola fez com que a demanda aumentasse e foi então escolhido para ser sede do Colégio Universitário, que, por ter sido criado pelo interventor federal Fernando Costa, prestou-lhe a homenagem com seu nome. 
Várias transformações ocorreram ao longo dos anos e, com a reestruturação do ensino, muitos alunos foram estudar em seus bairros. A escola, que é situada no centro do município, atende, hoje, alunos que residem no centro e aqueles que trabalham nas imediações, clientela esta constituída por filhos de comerciários, comerciantes, professores, profissionais liberais.

Atualmente recebe o nome de Escola Estadual Fernando Costa e oferece o Ensino Fundamental de $5^{\mathrm{a}}$ à $8^{\mathrm{a}}$ séries e Ensino Médio. Atende alunos do Ensino Fundamental - Ciclo II (5a a $8^{\mathrm{a}}$ séries) e Médio, com aproximadamente 1400 alunos. A escola organiza seus alunos e profissionais do Ensino Médio de acordo com os quadros abaixo:

QUADRO 3 - Organização dos alunos na Escola Estadual Fernando Costa:Ano base 2006.

\begin{tabular}{|c|c|c|c|}
\hline Organização dos a & os po & - Ensinc & \\
\hline Manhã & & & \\
\hline $1^{\circ}$ ano & 233 & $1^{\circ}$ ano & 86 \\
\hline $2^{\circ}$ ano & 123 & $2^{\circ}$ ano & 86 \\
\hline $3^{\circ}$ ano & 162 & $3^{\circ}$ ano & 87 \\
\hline Total por período & 518 & $\begin{array}{l}\text { Total por } \\
\text { período }\end{array}$ & 259 \\
\hline TOTAL GERAL & 777 & & \\
\hline
\end{tabular}

Fonte:Documentos da E.E. Fernando Costa Dados trabalhados pelo autor.

QUADRO 4 - Profissionais que atuaram na escola. Visão Geral. Ano Base 2006.

\begin{tabular}{|l|c|}
\hline Diretor de escola & 01 \\
\hline Vice - diretor de escola & 01 \\
\hline Professor coordenador pedagógico & 01 \\
\hline Professores efetivos & 33 \\
\hline Professores eventuais & 16 \\
\hline Professores readaptados & 07 \\
\hline Funcionários & 12 \\
\hline
\end{tabular}

Fonte:Documentos da Escola Estadual Fernando Costa/2006.Dados trabalhados pelo autor. 
QUADRO 5 - Qualificação profissional dos docentes em 2006.

\begin{tabular}{|l|r|l|l|l|}
\hline $\begin{array}{l}\text { Disciplinas em que } \\
\text { lecionam }\end{array}$ & $\begin{array}{l}\text { Licenciatura Plena - } \\
\text { Número de professores }\end{array}$ & Especialização & Mestrado & Doutorado \\
\hline Língua Portuguesa & 03 & & $\begin{array}{c}\text { 1 (Mestrado em } \\
\text { Educação) }\end{array}$ & 1 (Mestrado em \\
\hline Matemática & 02 & & Educação) & \\
\hline História & 03 & & & \\
\hline Geografia & 01 & & & \\
\hline Química & 02 & 1 & & \\
\hline Biologia & 02 & & & \\
\hline Física & 00 & & & \\
\hline Inglês & 00 & & & \\
\hline Sociologia & 02 & & & \\
\hline Filosofia & 02 & & \\
\hline Arte & 02 & & \\
\hline Ed. Física & 02 & & \\
\hline
\end{tabular}

Fonte: Documentos da Escola Estadual Fernando Costa/2006.Dados trabalhados pelo autor.

O quadro acima refere - se à qualificação dos profissionais que atuam no Ensino Médio, na Escola Estadual Fernando Costa, objeto da pesquisa, que demonstra que os professores têm qualificação, porém o número de aprofundamento é mínimo, ou seja, apenas dois professores possuem mestrado em educação.

Para conhecer o perfil dos alunos necessário se faz analisar as relações de trabalho no contexto em que a escola está inserida.

Observamos que a clientela é formada por alunos de diferentes classes sociais. Numa pesquisa realizada com os pais de alunos do Ensino Médio, num universo de 107 pais de alunos, ouvidos na escola, que corresponde a $7,1 \%$ de sua população, após coleta de dados entre as famílias que são usuárias da escola, 
responderam à pesquisa $73 \%$ de mulheres (mães ou responsáveis pelos alunos) e $23 \%$ de homens (pais ou responsáveis pelos alunos).

Em relação ao trabalho percebemos que, após análise dos dados confirmados pelo SEADE - Sistema Estadual de Análise de Dados - o maior índice (33\%) está no trabalho desenvolvido no comércio, banco ou transporte, com ligeira vantagem sobre atividades desenvolvidas por conta própria, ou seja, trabalho no setor privado com carteira assinada. Porém um dado que não podemos desprezar são os $16 \%$ que trabalham sem carteira assinada, caracterizado no setor informal e que não recebe direitos trabalhistas. Com isso, percebemos que a população que freqüenta a escola pública, mais precisamente a E.E.Fernando Costa, está caracterizada como de baixa e média renda.

Com a Progressão Continuada e as Classes de Aceleração de estudos, observamos que a idade dos alunos está compatível com as séries, ou seja, adentram o Ensino Médio com 14 ou 15 anos e concluem com 17 ou 18 anos. $\mathrm{O}$ índice de defasagem nas séries é pequeno.

Para incentivar a cultura e o acesso às informações, a escola possui em seu acervo centenas de livros literários, enciclopédias e encartes. Sua sala ambiente de informática - SAI - é constituída por dez computadores com acesso à Internet via Banda Larga que possibilita acesso a qualquer momento e por tempo ilimitado. Prestam serviços voluntários na SAI alunos monitores que são treinados por profissionais da Diretoria de Ensino, para auxiliarem alunos e professores no uso planejado no espaço virtual. Possui também acervo de software que é utilizado pelos professores como ferramenta de ensino.

Neste ambiente escolar é que procuramos acompanhar o desenvolvimento do projeto, contando com a participação dos agentes envolvidos no processo escolar, num movimento colaborativo.

\subsection{A investigação}

O delineamento do tema investigado deu-se a partir da pretensão de analisar a percepção dos professores que participaram do Programa Ensino Médio em Rede, enquanto proposta de formação continuada em serviço. Importante 
ressaltar que esse Programa se iniciou em 2004 e se estendeu pelos anos de 2005 e 2006.

Os aspectos que envolveram este tema foram compreendidos, modificados e aperfeiçoados no decorrer da pesquisa, por meio de reflexões teóricas e dos dados coletados.

\subsection{Sujeitos da Pesquisa}

Entendemos oportuno apresentar o Quadro 6 com o perfil dos profissionais colaboradores, para uma visão micro e leitura do tempo de serviço, qualificação profissional e carga horária a fim de compreendermos o contexto.

QUADRO 6 - Perfil dos participantes da pesquisa, de acordo com o tempo de serviço na escola, qualificação profissional e carga horária.Ano Base 2006.

\begin{tabular}{|c|c|c|c|c|}
\hline Sujeitos & $\begin{array}{c}\text { Tempo de serviço na } \\
\text { escola }\end{array}$ & $\begin{array}{l}\text { Tempo de } \\
\text { serviço }\end{array}$ & Formação profissional & $\begin{array}{l}\text { Carga horária } \\
\text { semanal em } \\
\text { horas }\end{array}$ \\
\hline P1 & 5 anos & 15 anos & $\begin{array}{l}\text { Matemática/ Mestrado } \\
\text { em Matemática }\end{array}$ & 150 \\
\hline $\mathrm{P} 2$ & 2 anos & 3 anos & Química & 190 \\
\hline P3 & 7 anos & 15 anos & Matemática & 200 \\
\hline P4 & 2 anos & 25 anos & História & 200 \\
\hline P5 & 26 anos & $\begin{array}{l}26 \text { anos } / 2^{\circ} \\
\text { cargo: Diretor } \\
\text { de escola }\end{array}$ & Física & 120 \\
\hline P6 & 3 anos & 5 anos & $\begin{array}{l}\text { Língua } \\
\text { Portuguesa/Inglês }\end{array}$ & 200 \\
\hline P7 & 3 anos & 20 anos & $\begin{array}{l}\text { Língua } \\
\text { Portuguesa/Inglês }\end{array}$ & 200 \\
\hline P8 & 2 anos & 4 anos & $\begin{array}{l}\text { Língua } \\
\text { Portuguesa/Inglês }\end{array}$ & 200 \\
\hline P9 & 2 anos & 27 anos & $\begin{array}{l}\text { Língua } \\
\text { Portuguesa/Inglês }\end{array}$ & 200 \\
\hline P10 & 15 anos & 22 anos & Geografia /Sociologia & 200 \\
\hline P11 & 8 anos & $\begin{array}{l}9 \text { anos } / 2^{\circ} \\
\text { cargo: Diretor } \\
\text { de escola }\end{array}$ & Biologia & 190 \\
\hline
\end{tabular}

Fonte: arquivos da E.E.Fernando Costa.Dados trabalhados pelo autor.

A leitura do quadro 6 permite-nos ter uma visão geral do perfil dos 
profissionais, que participaram dessa pesquisa. Observa-se que apenas um professor está em início de carreira. Os demais estão com cinco ou mais de dez anos na carreira de professor nesta escola. Um deles com tempo para aposentar-se e atuando como diretor em outra unidade de ensino, e outro aposentado como diretor de escola e atuando novamente como professor efetivo. De modo geral, buscam qualificação profissional por meio de cursos variados. Mesmo atuando com carga de trabalho duplicada, esforçam-se por superar as dificuldades da profissão e participam de formação continuada em serviço.

\subsection{O Desenvolvimento da Pesquisa}

\subsubsection{Primeiros contatos com o conteúdo do programa}

Ao entrarmos em contato com os documentos que norteariam o Programa, vislumbramos o desenvolvimento de uma formação continuada que vinha ao encontro das expectativas que tecíamos sobre o que seria uma formação voltada para aplicação, com acompanhamento sistemático, com reflexão sobre a prática educativa e com devolutiva.

Outra característica que nos chamou a atenção foi oportunizar aos professores acesso a um referencial teórico cuja bibliografia estava voltada para conhecimentos específicos sobre as questões que envolviam não só o Ensino Médio, mas também colocava o professor numa dinâmica que o levaria à reflexão sobre a interdisciplinaridade numa ação sobre a ação, "numa ruptura do individualismo pedagógico" (RODRIGUES; ESTEVES,1993, p.66).

O material base (CD com referencial teórico, o material impresso,o ambiente em rede via internet) disponibilizado aos professores consistia em ação deliberada e inovadora na rede estadual de ensino, por ser uma formação contínua em serviço, aplicada em horário de Hora de Trabalho Pedagógico Coletivo-HTPC-, dentro do espaço escolar, envolvendo os professores de uma mesma escola, que vivenciavam as mesmas ansiedades e com a mesma realidade. 
Esse panorama nos despertou a possibilidade de perceber a aplicabilidade de um Programa in loco e analisar a concepção dos professores sobre a aplicação do Programa.

Na visão dos professores, percebemos que não há consenso $(60 \%)$ de que o horário de HTPC seja modalidade efetiva de formação continuada. Deixaram claro que este espaço deveria ser utilizado para as discussões sobre o dia - a - dia da escola.

\subsubsection{Procedimentos e instrumentos da coleta de dados}

Essa pesquisa envolveu uma variedade de fontes de informações visto que, para traçar o perfil dos professores, foi necessário consultar os documentos existentes na escola relacionados à vida profissional, para se ter um parâmetro do tempo de serviço, suas qualificações porque entendemos como necessário já que no decorrer da aplicação do Programa o conhecimento global se sobrepunha ao específico.

Outra necessidade premente foi conhecer a trajetória da escola, visto que faz parte de um contexto e nele estão implícitos seus ideais, a "cultura da escola ${ }^{10 "}$, seu envolvimento com a comunidade e demanda a que atende.

Ao delinearmos a trajetória da pesquisa, foi preciso iniciar um contato com os professores, explanar sobre as intenções da pesquisa e solicitar a colaboração da equipe escolar.

\footnotetext{
${ }^{10}$ Cultura da escola aqui entendida como seu contexto, suas crenças, símbolos, ideologia defendida pela administração e pelo grupo, Conjunto de sentidos e significações, de valores e padrões, incorporados e subjacentes aos fenômenos perceptíveis de ação e comunicação da vida de um grupo ou sociedade concreta. Um conjunto que, consciente ou inconscientemente, é vivido e assumido pelo grupo como expressão própria de sua realidade humana e passa de geração em geração, conservado assim como foi recebido ou transformado efetiva ou pretensamente pelo próprio grupo.
}

A visão dos professores e do professor-coordenador sobre o Programa e a aplicação foi coletada por meio de dois instrumentos, sendo um questionário 
(Anexo 2) com objetivo de investigar a formação docente, dados profissionais e concepção sobre o Programa; com isso, reforçamos o que nos revela Taylor e Bogdan (apud LUDKE; ANDRÉ,1986, p. 20), dito anteriormente que a expressão metodologia qualitativa que se refere "à investigação que produz dados descritivos: as próprias palavras das pessoas, faladas ou escritas e a conduta observável". Obtivemos $100 \%$ de devolução desse instrumento.

No segundo instrumento (Anexo 3) foi elaborado um roteiro para entrevista aberta, semi - estruturada para analisar o contexto, de forma que os professores-colaborados pudessem demonstrar seus anseios, expectativas e dificuldades, sem desprezar os aspectos subjetivos.

O registro dos dados foi realizado por meio de um esquema com a síntese das concepções dos sujeitos - colaboradores. Para efetivar a análise, recorremos a dois tipos:

a) Registro por meio de pontos positivos;

b) Registro por pontos negativos.

Após analisarmos os dados, reexaminamo-los para detectarmos a reiteração de alguns aspectos, que surgiram e reapareceram em diferentes discursos, confirmando o já dito anteriormente, que a análise de dados qualitativos é um processo criativo que exige grande rigor intelectual e dedicação. Não existe uma forma melhor ou mais correta. O que exige é sistematização e coerência do tema escolhido com o que pretendeu o estudo. PATTON ( apud LUDKE ; ANDRÉ,1996 ).

Nosso olhar recaiu sobre a veracidade dos fatos, sobre os discursos dos professores e sobre suas ações no decorrer do desenvolvimento do Programa, e também sobre os registros do professor-coordenador ( QUADRO 14, em Anexo)

Para que não houvesse interferência nas análises, colocamo-nos de forma imparcial, sem pré - concepções, nem juízo de julgamento, para validar o estudo. Por meio de leituras atentas dos discursos dos sujeitos-colaboradores procuramos transcrevê-los de forma fiel, o que requereu grande cuidado para não se 
desviar do objeto pesquisado.

Procuramos realizar uma leitura cuidadosa e criteriosa dos discursos dos sujeitos-colaboradores, assim optamos por simplificá-los, mas preservando sua essência e também a linguagem utilizada pelos professores e ou professor coordenador. Ao sintetizarmos essas unidades, demonstramo-los por meio de asserções articuladas aos discursos, gerando o Quadro 7, descrito no próximo capítulo. 


\section{ANÁLISE DOS DADOS}

e os dados...."serão vistos em função de sua situação no conteúdo em função do conjunto dos outros elementos aos quais se vêem ligados e que Ihes fixam o sentido e o valor". (LAVILLE; DIONNE, 1999, p. 217).

Neste capítulo buscamos, por meio da análise dos dados selecionados, investigar as concepções dos docentes em relação à formação continuada de professores quanto à aplicação do Programa Ensino Médio em Rede.

Para tanto, são destacados e comentados os indicadores identificados nos instrumento de coleta de dados. Vale salientar que esses indicadores não foram definidos a priori, mas se constituíram, a partir da análise dos comentários dos sujeitos da pesquisa, nos diferentes instrumentos de coleta de dados. O Quadro 7 descreve os indicadores que serão detalhados neste capítulo, e os Quadro de 8 a 14, (Anexo 5 ), demonstram o acompanhamento da realização das atividades pelo professor-coordenador.Interessante ressaltar que esses quadros demonstram a evolução dos trabalhos.

Nesta pesquisa procuramos focar a qualidade dos indicadores, não nos preocupando apenas com a quantidade.

Dentre os dez professores, e o professor-coordenador pedagógico, colaboradores da pesquisa, 100\% estão realizando o Programa Ensino Médio em Rede desde o seu início, ou seja, desde 2004.

Ao procedermos as análises dos dados coletados entre os participantes e, à luz dos documentos, o faremos por categorias.

Foram entregues dez questionários, ou seja, um para cada participante da pesquisa, todos devolveram e um do professor-coordenador que foi 0 multiplicador da equipe. (Anexo 2).

Apresentaremos estes resultados em forma de quadro (Quadro 7), para leitura e melhor compreensão, esclarecendo que os sujeitos colaboradores foram identificados por meio de símbolos, ou seja, códigos P1,P2,P3,P4,P5,P6,P7,P8,P9,P10,P11, para garantir o anonimato. São educadores 
de diversas disciplinas e o sujeito $P 11$ foi o multiplicador da turma, ou seja, o professor-coordenador, responsável pela equipe.

\section{QUADRO 7- Confluências temáticas e sujeitos /unidade de significado}

\begin{tabular}{|c|c|}
\hline Confluências temáticas & Sujeitos/unidade de significado \\
\hline $\begin{array}{l}\text { CT 1-Motivos que os levaram a participar do } \\
\text { Programa }\end{array}$ & \\
\hline Melhoria da qualidade do ensino & $\mathrm{P} 1, \mathrm{P} 2, \mathrm{P} 3, \mathrm{P} 4, \mathrm{P} 5, \mathrm{P} 11$ \\
\hline Adquirir conhecimentos & P1,P2,P3,P6,P7,P8,P9,P10. \\
\hline Progressão funcional & P1,P2,P3,P4,P7,P8,P9P10. \\
\hline Aprender novas metodologias & $\mathrm{P} 1, \mathrm{P} 2, \mathrm{P} 3, \mathrm{P} 4, \mathrm{P} 5, \mathrm{P} 6, \mathrm{P} 7, \mathrm{P} 8, \mathrm{P} 9, \mathrm{P} 10$. \\
\hline 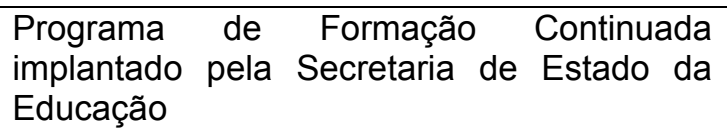 & P11 \\
\hline Trabalhar melhor a interdisciplinaridade & P4,P5,P6,P7 \\
\hline $\begin{array}{l}\begin{array}{l}\text { Elevar o nível do processo ensino } \\
\text { aprendizagem }\end{array} \\
\end{array}$ & $\mathrm{P} 18, \mathrm{P} 9, \mathrm{P} 10$ \\
\hline $\begin{array}{l}\text { CT 2- Um dos objetivos do Programa diz } \\
\text { respeito a desenvolver a capacidade } \\
\text { escritora e leitora.Esse objetivo favoreceu ao } \\
\text { que se propôs }\end{array}$ & $\begin{array}{l}\text { Muito:P1,P2,P3,P4,P5,P7,P8,P9,,P11 } \\
\text { Razoavelmente:P10 } \\
\text { Pouco:P6 }\end{array}$ \\
\hline $\begin{array}{l}\text { CT 3- O Programa se propôs a promover a } \\
\text { integração entre os professores e entre as } \\
\text { áreas, a partir de uma perspectiva } \\
\text { interdisciplinar.A integração ocorreu? }\end{array}$ & $\begin{array}{l}\text { Muito: P1,P2,P3,PP4,P5,p7,P8,P9,P11 } \\
\text { Pouco:P10 } \\
\text { Poderia ser melhor:P6 }\end{array}$ \\
\hline $\begin{array}{l}\text { CT4 - Fortalecer as equipes escolares para } \\
\text { dar suporte a mudanças na prática } \\
\text { pedagógica }\end{array}$ & $\begin{array}{l}\text { Muito: P5,P11 } \\
\text { Pouco: P6,P9,P10 } \\
\text { Razoavelmente:P1,P2,P3,P4,P7,P8. }\end{array}$ \\
\hline $\begin{array}{l}\text { CT5 - Utilização de novas metodologias, por } \\
\text { meio de diversas mídias interativas. }\end{array}$ & $\begin{array}{l}\text { Sim;P1,P2,P3,P5,P7,P8,P11 } \\
\text { Não } \\
\text { Em parte: P4,P6,P9,P10. }\end{array}$ \\
\hline $\begin{array}{l}\text { CT6-O uso dos ambientes de ensino e } \\
\text { aprendizagem por meio de mídias e } \\
\text { tecnologias tem favorecido em que sentido? }\end{array}$ & $\begin{array}{l}\text { Favorece a aprendizagem: } \\
\text { P1,P2,P3,P4,P5,P6,P7,P8,P9,P10,P11. } \\
\text { Poderia ser melhor explorado: } \\
\text { P4,P5,P6,P7,P8,P9,P10. }\end{array}$ \\
\hline $\begin{array}{l}\text { CT7-A Proposta Pedagógica da escola foi } \\
\text { analisada? }\end{array}$ & $\begin{array}{l}\text { Sim:P1P2,P3,P4,P7,P8,P9,P10,P11 } \\
\text { Não foi analisada:P5,P6. }\end{array}$ \\
\hline $\begin{array}{l}\text { CT } 8 \text {-Os objetivos do Ensino Médio estão } \\
\text { claros para você? }\end{array}$ & $\begin{array}{l}\text { Sim:P2,P11 } \\
\text { Relativamente claro: } \\
\text { P1,P3,P4,P5,P6,P7,P8,P9,P10. } \\
\text { Não: }\end{array}$ \\
\hline
\end{tabular}

Fonte: Pesquisa por meio de questionário. Dados trabalhados pelo autor

Em seguida, demonstraremos a análise desses dados ou o que 
podemos perceber diante das respostas confrontadas com a teoria na qual nos embasamos.

\subsection{Razões da Busca da Formação Continuada ( CT1 )}

São inúmeras as razões para a busca da formação continuada, entre elas como já citado anteriormente, alguns buscam conhecimento, atualização; outros ganharem créditos, promoção via não acadêmica, sair da sala de aula. Neste sentido, ao analisarmos as produções dos professores envolvidos no Programa Ensino Médio em Rede, conforme dados do Quadro 7, observamos que a formação continuada de professores contribuiu para a formação, enriquecendo o trabalho.

Acreditamos que a formação em serviço contribuirá para o trabalho de professores mais competentes, como dito anteriormente, para que desenvolvam seu trabalho de forma intencional e oportunize aprendizagem de conhecimentos voltados para o científico, para a análise de suas próprias produções, porque ainda há educadores cujo perfil se enquadra nas observação de Cró (1998, p. 76) "Hoje os educadores experimentam freqüentemente dificuldades em perceber o papel da formação continuada pela aprendizagem de sua prática”.

Os dados do Quadro 7 revelam que os participantes, ao serem perguntados sobre os motivos pelos quais os levaram a se envolver com esse Programa demonstram que a maioria busca adquirir conhecimentos, melhoria da qualidade do ensino, progressão funcional, atualização, aprender novas metodologias e utilizar melhor as HTPCs (Horas de Trabalho Pedagógico Coletivo).Como justificativa, responderam que ao participar do Programa Ensino Médio em Rede o professor “...elevará o nível de seu processo ensino e aprendizagem, buscando novas possibilidades e metodologias e melhorar a interdisciplinaridade" (P.3) .Interessante ressaltar que o questionário foi aplicado no primeiro bimestre do ano de 2006 e a entrevista foi aplicada no final do ano de 2006, quase no encerramento da aplicação do Programa.

Um pequeno grupo (2 professores) deixou de responder a este questionamento, talvez por outras razões que se coadunam com as citadas por 
Huberman, (apud CRÓ, 1998, p. 76): "ganhar créditos, reencontrar os colegas" ou por outro lado há o "desânimo" de que nos fala Imbernón (2006, p.14) que abala o professor em decorrência da:

... perplexidade ou consternação difícil de objetivar, fruto de um acúmulo de variáveis convergentes, entre as quais podemos citar o aumento de exigências, com a conseqüente intensificação do trabalho educacional, a desprofissionalização resultante da falta de uma clara delimitação das funções dos professores, a rápida mudança social e mesmo um tipo de formação permanente que parece conduzir de novo a um modelo transmissivo (de lições-modelo, de noções, de ortodoxia, de competências, etc.).

\subsection{Percepção dos Professores Frente aos Objetivos do Programa ( СT2)}

As diferentes concepções foram construídas pelas experiências e informações pessoais, bem como idéias socialmente construídas e transmitidas pela cultura da qual fazemos parte. Observamos que $80 \%$ dos participantes, são otimistas em relação à formação continuada e buscam a melhoria da qualidade do ensino visto que, pelo discurso, estão correlacionadas com os objetivos do Programa Ensino Médio em Rede, e as expectativas se convergem.

Dentre algumas expressões significativas dos professores, destacamos uma argumentação que deixou claro esta percepção:

Os objetivos do programa estão relativamente claros para mim. Percebo que visa desenvolver competências ligadas à leitura e escrita, proporcionar a interdisciplinaridade, criando uma rede disciplinar com várias formas de leitura e escrita (P1).

A aprendizagem ocorre de modo gradual e contínuo e os professores são partes desse processo, assim o tempo para internalização não é igual para todos. Uns demandam um tempo maior para internalizar ou relacionar esses objetivos com a prática ou mudança de paradigma, como podemos perceber nesta observação de um outro professor: "À medida que as atividades vão se 
desenvolvendo os objetivos vão se tornando cada vez mais claros"(P 2).

Alguns ainda argumentam que "Falta mais prática ficamos presos em leituras onde não podemos às vezes nem respirar para trocar idéias"( $(\mathrm{P} 3)$.

Esta diversidade de concepções produz também a diversidade de maneiras de trabalhar dos professores, isso porque são os alicerces sobre os quais foram construídos seus trabalhos. Estas opiniões nos remetem às teorias de Cró (1998,p.78) que salienta que na formação contínua há que se levar em conta as concepções dos aprendizes, que apresentam muitas variáveis. Argumenta a autora que "Primeiramente podemos encontrar uma justificação ética e epistemológica no estudo do ponto de vista dos sujeitos em relação ao fenômeno".

De acordo com Cró (1998, p.78), nesta perspectiva é importante ainda considerar a pessoa, sua história, a motivação que o levou a participar da formação, o contexto em que vive e a singularidade dos indivíduos.

\subsection{Integração / Articulação entre as Disciplinas ( CT3 )}

Um dos objetivos do Programa consiste em promover a integração entre os professores das áreas, a partir de uma perspectiva interdisciplinar de discussão sobre os conteúdos do Ensino Médio. Diante disso, foi perguntado ao grupo se a mencionada integração proposta durante o Programa realmente ocorreu.

Diante da pergunta, a maior parte dos professores, (80\%), acreditam que a integração entre as áreas está ocorrendo, 10\% respondeu que gostaria que fosse melhor, que a interdisciplinaridade ocorresse de forma contínua, e ainda $10 \%$, respondeu que pouco se está avançando e justificou que há somente leituras dos textos e falta espaço para reflexões e discussões.

Uma das atividades proposta aos educadores pelo Programa, consistia em organizar os professores de diferentes disciplinas, para que elaborassem atividades ou um projeto tendo como foco o trabalho em sala de aula, culminando na elaboração de artigo de opinião. Os grupos realizaram atividades articuladas, como, por exemplo, um Projeto que articulou as disciplinas de Língua Portuguesa, Filosofia e Arte,desenvolvendo a intenção da Vivência Educadora 3, produzindo um 
artigo de opinião. Este grupo trabalhou diferentes textos, jornalísticos e literários, inclusive com proposta de redação apresentada em vestibular. Ao final propôs interpretação e produção de textos para os alunos do ensino médio, explorando e produzindo artigo de opinião. O resultado, de acordo com os professores, foi satisfatório e .

Dentre os professores, $60 \%$ disseram que buscaram renovar suas práticas e se predispuseram a articular as disciplinas, reconhecendo-se como parte de um todo. Tiveram um novo olhar sobre suas disciplinas e perceberam as relações entre as áreas de ensino. No início estavam temerosos, mas, aos poucos, foram se articulando. Percebemos, pelas respostas dos professores aos questionários e pelas aulas diferenciadas que a parcela que ansiava por mudanças conseguia articular-se com outras disciplinas e elaborou aulas interdisciplinares (Anexo 4) .

$\mathrm{Na}$ visão da professora - coordenadora pedagógica, capacitadora do Programa nesta escola:

\begin{abstract}
Os professores participantes do Programa Ensino Médio em Rede têm discutido nos HTPCS as especificidades curriculares do Ensino Médio em Rede, momentos de discussão coletiva com a participação de todos os professores das diferentes disciplinas. Outros momentos são para discussão e estudo das especificidades de cada disciplina (grupo de professores da disciplina) e depois de cada área de estudos. Os trabalhos finais de cada área são socializados. Há ainda o início de um trabalho coletivo interdisciplinar que prevê a aplicação de projetos em sala de aula. No momento, os professores trabalham com seqüências didáticas e enunciados de problemas.
\end{abstract}

Sob as luzes de Berbaum (apud CRÓ, 1998, p.83) há interações que intervêm na formação contínua: desejo de mudança, pôr em projeto, aprendizagem, mudança e novo desejo de mudança. De outra forma quer dizer que na mudança da prática há elementos que interferem ou contribuem para que isso ocorra. Se não houver o desejo de mudança, nada ocorre, mas o desejo por si só não basta, há que se pôr em prática ou em projeto. Quando isso ocorre, há a mudança e aprendizagem, desencadeando um novo desejo.

Um índice de $60 \%$ dos professores demonstrou desejo de mudança, puseram em prática, mudaram o conceito e ou maneira de olhar as disciplinas e estão motivados para novos projetos. Argumentaram ainda que, ao elaborarem os 
projetos de ensino interdisciplinares, tornou-se o processo significativo "porque os projetos proporcionaram momentos de integração e discussão, entre as diferentes disciplinas que compõem o currículo" (P5).

A professora-coordenadora elaborou síntese para acompanhamento das atividades realizadas pelos professores e as articulações entre as disciplinas, conforme o Anexo 5 .

\subsection{Desenvolvimento de Competências e Habilidades ( CT 4 )}

Frente a um outro objetivo do Programa Ensino Médio em Rede, que diz respeito a desenvolver competências leitoras e escritoras dos agentes educacionais de Ensino Médio e fornecer subsídios para que os professores possam também desenvolver essas competências em seus alunos, observamos que o Programa pretendeu estabelecer uma discussão, voltada às melhores formas de desenvolver a proficiência da leitura e da redação dos alunos.

$\mathrm{Na}$ Vivência Formadora, os professores analisaram e discutiram os dados do SARESP/2003 - Sistema de Avaliação dos Rendimentos Escolares do Estado de São Paulo, com foco no perfil leitor do aluno; análise das práticas dos professores das diferentes áreas, identificando as competências desenvolvidas nas atividades de leitura e produção de texto; definição do projeto de trabalho que os professores desenvolveriam na sala de aula, levando em conta que deveria ser interdisciplinar, visando à competência leitora e escritora e como produto final um artigo de opinião e enunciado de problema ; e a retomada do projeto político pedagógico e dos planos de ensino.

Esse movimento de leituras (Vivências Formativas), análises, observações e produções (Vivências Educadoras) contribuíram para que professores da Área de Exatas percebessem que a capacidade leitora e escritora deve ser compromisso de todos, e não, especificamente dos professores de Língua Portuguesa, ficando evidenciado na fala de um professor de Física que "cada vez mais as competências leitoras e escritoras, são requeridas pelo mercado de 
trabalho, onde a criatividade, autonomia e a capacidade de solucionar problemas têm destaque muito importante" (P6).

Com isso, intensificaram-se reflexões sobre a competência leitora e escritora dos professores. Nesse sentido, foram inseridos escritores que em suas teses discorreram sobre a importância da prática leitora e escritora. Assim uma das atividades desenvolvida no Programa consistia em trabalhar com os alunos textos argumentativos. Para isso, os professores sentiram necessidades de conhecer melhor este gênero textual.

Exemplificando as concepções, percebemos no discurso do professor:

Embora entenda a Matemática como uma linguagem e procure trabalhar o ensino da matemática com interpretações, reflexões e produções de significados, hoje fica mais claro para mim que isso é próprio do desenvolvimento das habilidades de leitura e escrita. É uma habilidade que deve ser trabalhada ou desenvolvida por todas as disciplinas, não apenas por Português (P1).

A partir dessa fala do professor, fica claro o que Hernandez (2006, p.10) revela:

...já há algum tempo, consideramos que a experiência de formação não deve vir de fora, como uma tecnologia salvadora que promete a solução ou o remédio para os problemas da educação. O conteúdo e o processo da formação devem partir dos sujeitos.

Nessa perspectiva, a aprendizagem do professor buscou mudança de conceitos baseando-se na construção de sua própria aprendizagem, como sujeito que vai apoderar-se de um saber, que irá refletir sobre seus próprios conceitos e internalizá-los, como nos revelou o exemplo do professor acima. E como justificativa, argumenta que entende que as competências leitoras e escritoras, cada vez mais, são requeridas para inserção no trabalho.

Por outro lado, alguns professores ainda não perceberam a relação entre teoria e prática. Dentre os professores que participaram dessa pesquisa $20 \%$ acreditam que há muita leitura sem prática. Para esses professores a prática educativa é o fazer, o preparar aulas, ou seja, a prática pela prática, percebido por 
meio dos questionários respondidos por eles,como citado, nesta fala "Falta mais prática ficamos presos em leituras onde não podemos às vezes nem respirar para trocar idéias" (P 3).

Ainda acreditam que a teoria está desvinculada da prática. Nesse sentido o facilitador ou coordenador do grupo precisa voltar o olhar com mais intensidade, procurando incentivá-los, procurando perceber, porém, quais suas dificuldades, suas representações para alcançar os objetivos propostos.

\subsection{Utilização de Novas Metodologias por Meio de Diversas Mídias ( CT 5 )}

Quanto ao uso das tecnologias, o Programa tem como meta, possibilitar aos agentes educacionais o conhecimento e a utilização de novas tecnologias de comunicação e informação, por meio do uso de diversas mídias interativas, discutindo seus usos na continuidade da sua própria formação e na sua prática educativa.

Diante do questionamento, um percentual de $70 \%$ respondeu que o assunto foi debatido, justificando que o assunto foi discutido em HTPC, com textos reflexivos, que nortearam as ações, porém outra parcela dos professores, $30 \%$ respondeu que, em parte, alegando que poderia ser melhor explorado e, ainda, que uma das maiores dificuldades na transferência do conhecimento é o "como" fazer. Esclarecem que a proposta do Programa e os objetivos são bons, mas a maneira como é ministrado, em HTPC, limita o tempo. A partir dessas argumentações, podemos retomar a teoria do construtivismo, citado anteriormente, o construtivismo valoriza as ações do sujeito.

Para Morelatti (2006, p. 4), o computador no processo de ensinar e aprender : 
... pode causar uma grande revolução no processo de ensino e aprendizagem se for utilizado não para "informatizar" os processos tradicionais, mas se for introduzido na escola numa perspectiva de mudança do paradigma pedagógico vigente. A mudança do paradigma educacional deve ser acompanhada da introdução de novas ferramentas que devem facilitar o processo de expressão do nosso pensamento. E esse é um dos papéis do computador no processo de ensinar e aprender .

Percebemos que a inclusão digital, necessária nesse Programa, deixou de ser parte integrante das ações. Para Ralston (2006, p. 68):

\begin{abstract}
A principal finalidade da tecnologia é o desenvolvimento do potencial humano, E o que é o potencial humano, senão a capacidade de homens e mulheres realizarem suas habilidades de forma plena, ideal que a humanidade vem buscando em toda sua história?.
\end{abstract}

Acreditamos que o ser humano possui capacidade em desfrutar das facilidades na comunicação, no viver plenamente e com as facilidades de acesso à cultura e à participação nas conquistas sócio - econômicas.

De acordo com a professora - coordenadora pedagógica (PCP), multiplicadora do Programa Ensino Médio em Rede, nesta escola "O professorcoordenador pedagógico (PCP) e professor representante (PR) utilizam com maior freqüência as tecnologias. Vídeos, retroprojetor, DVD, são utilizados por todos (PCP,PR e professores em geral)".

\title{
5.6 O Uso dos Ambientes de Ensino e Aprendizagem por Meio de Mídias e Tecnologias na concepção dos professores ( CT6)
}

As transformações ocorrem em velocidade acelerada em todos os setores da sociedade e a tecnologia dinamizou esse processo. Na era da pós modernidade, as informações são quase que instantâneas e a escola precisa internalizar essas tecnologias. O computador constitui-se como uma ferramenta de trabalho que propicia rapidez e amplitude ao trabalho. A escola que tem como 
finalidade estimular e oportunizar ao educando o desenvolvimento integral de suas potencialidades, nos aspectos físicos, psicológicos, intelectual e social, precisa se apoderar das tecnologias a seu favor.

A importância no processo de ensino e aprendizagem das mídias interativas, por unanimidade, foi reconhecida pelos professores. $100 \%$ responderam que a tecnologia é importante no processo, porém $70 \%$ gostariam que fossem melhor explorados durante o desenvolvimento do Programa., confirmando a hipótese de que se torna necessária a contextualização e a devolutiva, uma vez que o que se experiência se internaliza.

Analisando os questionários, percebemos que os professorescolaboradores deixaram de exemplificar ou relatar de que forma estão ocorrendo as inovações ou contribuições no uso das tecnologias.

Concordamos com Almeida (2001, p.1) quando nos fala que "Com o uso da tecnologia de informação e comunicação, professores e alunos têm a possibilidade de utilizar a escrita para descrever/reescrever suas idéias, comunicarse, trocar experiências e produzir histórias".

\subsection{Análise do Projeto Político Pedagógico ( CT 7)}

Analisar o Projeto Político Pedagógico, ou Proposta Pedagógica esteve na pauta deste Programa. Diante disso, ao questionar com os envolvidos, obtivemos como resposta que em vários momentos houve análise do Projeto. Alguns professores relatam:

No planejamento inicial do ano letivo houve espaço para esta análise, no sentido de chegar ao senso comum, a respeito de todas as ações e situações que envolvem os educadores e os educandos e, todo o sistema de ensino e aprendizagem que envolve cada segmento da escola.(P5) 
Outros professores argumentaram que a Proposta "...está em fase de construção"(P5). Ao analisar os relatos, percebemos que os professores conhecem a Proposta, sabem os objetivos, as habilidades elencadas a serem desenvolvidas durante o ano letivo. Acreditamos que a construção do Projeto Político pedagógico, pela equipe escolar, torna-se importante, porque nessa construção fica evidenciado o perfil da escola e as ações propostas revelam as intenções do grupo, Essas ações refletem os anseios dos elementos de todos os segmentos que compõem a escola, e seus elementos tornam-se co-responsáveis pela busca da qualidade do ensino. Com isso os objetivos do Programa foram alcançados.

Concordamos com Rios (1992, p. 75 ) quando nos coloca que:

\begin{abstract}
Para elaborar um projeto é necessário, então, considerar criticamente com clareza, profundidade e abrangência, repetimos - os limites e as possibilidades do contexto escolar,definindo os princípios norteadores da ação, determinando o que queremos conseguir,estabelecendo caminhos e etapas para o trabalho, designando tarefas para cada um dos sujeitos envolvidos e avaliando continuamente o processo e os resultados.
\end{abstract}

Com esses relatos, podemos perceber que a construção do Projeto Político Pedagógico na escola está avançando e que há participação dos professores na elaboração deste documento que norteia toda prática educativa, mas "exige uma reflexão da equipe escolar para avaliar as ações planejadas e desenvolvidas ao longo do período previsto" (BRASIL, 2000, p.10) .

Acreditamos que a elaboração do Projeto Político Pedagógico nesta unidade escolar está sendo construída com a equipe escolar. A análise criteriosa de sua aplicação será ao longo do tempo e depende da implantação da cultura da avaliação para ser explorado.

\title{
5.8 Os Objetivos do Ensino Médio na Visão dos Professores (CT8)
}

Há alguns anos, em certos cursos de licenciaturas, os professores estudavam por três anos as disciplinas específicas, ocorrendo em determinadas 
Universidades a precariedade, no tocante à formação do docente em relação às disciplinas pedagógicas, gerando um desconforto, visto que em sala de aula não basta dominar o conteúdo específico. É sabido que o Ensino Médio ministrado por professores especialistas, muitas vezes sem conhecimentos pedagógicos, fragmentou o ensino.

Essa organização, em face de novo olhar sobre o Ensino Médio, vem mudando acentuadamente. Alguns cursos remodelaram seus currículos e inseriram na formação dos professores as referências pedagógicas.

Um dos objetivos do Programa Ensino Médio em Rede consiste em promover a discussão sobre as especificidades curriculares do Ensino Médio e a articulação das disciplinas.

As respostas dos professores - colaboradores demonstraram que um grupo percebeu que o currículo do Ensino Médio precisa ser reorganizado, e descrevem suas propostas como se propondo o desenvolvimento das capacidades de pesquisa de buscar, analisar, relacionar e apreender informações de criar e formular estratégias de resolução de problemas ( $P$ ).

Porém em outro grupo há um discurso pronto, que nos parece ser posto, sem, contudo, ser analisado profundamente ou ter nova proposta para esta modalidade de ensino. Acredita-se que o ensino médio "deve preparar para o vestibular", ou não tendo uma função definido; ou seja, os alunos que vão partir para o vestibular procurarão outros caminhos e os que irão para o mercado de trabalho saem sem qualificação.

Marton, seus colaboradores citados por Cró (1998, p.87) juntaram as concepções do como e do quê sobre as dimensões das condições de mudança de aprendizagem e formularam o esquema através de variáveis que implicam em :

Variáveis individuais que implica:

- Visão de si;

- Representação das estratégias de formação

-Representação do fim em vista

Variáveis Relacionais:

Concepção da aprendizagem:

- Visão de si; 
-Representação das estratégias de formação

-Representação do fim em vista

-Concepção da mudança de prática que implica na concepção da aprendizagem

-Variáveis situacionais:

-Contexto de formação

-Concepções dos formadores a propósito da aprendizagem do professor ou do educador.

Cró (1998,p.89) nos revela que esta "visão de si” pode ser vista como ‘ alguém passivo" que recebe as informações e poderia estar relacionada "às condições de aprendizagem do tipo aquisição de conhecimentos". Por outro lado também, a "visão de si" pode ser analisada como " criador de conhecimentos" e estar associada "às concepções de aprendizagem do tipo construção de conhecimentos", que tem outra conotação. Esta mudança então poderia estar relacionada com a construção do desejo de conhecer para então mudar.

Como podemos perceber, a mudança envolve um investimento pessoal, profissional, um trabalho de equipe que demanda um tempo maior.

\subsection{Um Olhar Sobre as Observações dos Professores Sobre o Programa}

Ao entrevistarmos os professores-colaboradores, objetivamos observar suas concepções sobre o desenvolver do Programa Ensino Médio em Rede, bem como suas percepções sobre as contribuições que o Programa ofereceu para a melhoria ou modificação da prática pedagógica.

A partir dessas entrevistas, desenvolvemos uma matriz, que nos permitiu elencar as categorias abertas, com as invariantes que revelaram os aspectos convergentes dos sujeitos pesquisados, deixando o individual para 0 sentido geral. Obtivemos as categorias abertas: 
CA1 - Dificuldades na realização do Programa.

CA2 - Facilidades na realização do Programa.

CA3 - Contribuição que o Programa trouxe.

CA4 - Material de apoio utilizado.

CA5 - Mudança de concepção ou metodologia.

CA 6 - Quais modificações fariam no Programa.

\section{Convergências}

\section{CA1 - Dificuldades na realização do Programa}

Os sujeitos - colabores da pesquisa revelaram que sentiram dificuldades:

- Na elaboração de atividades que abraçassem as disciplinas da melhor forma possível. Acreditamos que, conforme nos demonstra Valente (2006, p.60), o modelo de escola que ainda perdura, foi desenvolvido no início do século XX, sobretudo sob influência dos Estados Unidos e a explosão industrial que introduzia a concepção baseada no Taylorismo que pregava sobre a produção em massa nas indústrias, com conhecimento subdividido, ou seja, a produção nas fábricas eram realizadas em partes. Este conhecimento influenciou toda a sociedade.

O Programa buscou a interdisciplinaridade objetivou colocar em discussão essa concepção. Assim os professores, ao elaborarem atividade em grupo, independente da disciplina que lecionavam, puderam refletir sobre a necessidade do conhecimento global e não compartimentado. O referencial teórico que embasou o Programa trouxe novas luzes para os professores que 
atuam no Ensino Médio. Com isso as mudanças se farão necessárias, ao longo do tempo.

-Tempo para realização das atividades.

O grupo, ao apontar as dificuldades em refletir sobre a prática pedagógica, demonstrou aquilo que Schön (1992) argumenta como os três fundamentos: conhecimento da prática, reflexão da prática e reflexão sobre a prática. Para ele, o profissional, no seu fazer cotidiano, traz um conhecimento que utiliza para a solução de diferentes questões. É um conhecimento na prática. Esse conhecimento "manifesta-se na espontaneidade" (ALARCÃO, 1996, p.18) e, portanto, não traz o dado da sistematização. É um conhecimento que se expressa na execução de uma dada tarefa, sem ter a necessidade de uma reflexão prévia.

Poderíamos pensar que uma das necessidades apontadas seria a que Perrenoud (1998), nos relata que se a prática reflexiva fosse adquirida desde a formação inicial, tornar-se-ia parte da identidade profissional do professor.

\section{- As leituras}

Os professores ao sentirem dificuldades com as leituras apontaram que houve falta de tempo para reflexões mais profundas sobre cada tema, o que denuncia que, embora os assuntos fossem pertinentes, para os próximos programas há que se repensar sobre o cronograma, visto que os educadores quando participam da formação continuada, abarcam outras responsabilidades ao mesmo tempo, ficando difícil disponibilizar horários somente para estudos.

Houve por parte do professor-coordenador toda uma preocupação com a organização e realização dos encontros semanais, tendo em vista a realização das leituras e a condução das discussões. O professor - coordenador seguia um planejamento e cronograma para que houvesse seqüência lógica e utilização dos materiais.

Uma outra preocupação do professor-coordenador foi quanto aos conteúdos da proposta do Programa. A estruturação era subdividida em etapas, com tempo previsto para cada uma delas. Mesmo tendo recebido capacitação prévia, era necessário estudo e reorganização a fim de superar as 
expectativas e motivar 0 grupo. As atividades eram realizadas com intencionalidade, possibilitando a adequação do programa à realidade profissional, com apoio na reflexão sobre a prática.que as estratégias exigiam.

\section{CA2 - Facilidades na realização do Programa}

\section{Como facilidade: elaborar atividades didáticas}

Uma das facilidades apontadas pelos professores diz respeito ao planejar o desenvolvimento das aulas, ou seja, propor uma seqüência a priori de atividades coerentes com a representação das capacidades dos estudantes e com as metas a serem atingidas. Entendemos como prática toda a atividade de ensinoaprendizagem que envolva a demonstração, a observação ou a investigação de um fenômeno (físico, químico ou biológico), em sala de aula, em laboratório ou em ambiente externo.

Entendemos que todas as atividades práticas deveriam ser conduzidas de maneira que estimulassem a intensa atividade mental dos alunos, assegurando a construção de esquemas e não só a memorização de informações. Nesse sentido os professores-colaboradores dessa pesquisa demonstraram que, durante a realização do Programa Ensino Médio em Rede, elaboraram aulas com o propósito de instigar a curiosidade dos alunos e intensificar as atividades mentais.

\section{CA3 - Contribuição que o Programa trouxe}

Apontaram como contribuição: reformular a prática pedagógica. A necessidade de projetos interdisciplinares. Trabalhar em grupo. Novas aprendizagens sobre produção de diferentes gêneros de textos.

Percebemos, então, a confrontação de olhares plurais na observação de situações de aprendizagem. Daí a necessidade de um trabalho de equipe realmente voltado para a interdisciplinaridade. Isso não significa que ao adotar o 
trabalho interdisciplinar, seja esquecida a especificidade de cada disciplina; ao contrário, esta metodologia conduz à articulação das disciplinas.

Nesse sentido Lück (1995) conceitua a interdisciplinaridade como um processo que envolve a integração e, ao mesmo tempo, o engajamento dos professores num trabalho conjunto de interação das disciplinas do currículo escolar entre si e com a realidade, de modo a superar a fragmentação do ensino. Objetivando a formação integral dos alunos, a fim de que possam exercer criticamente a cidadania, mediante uma visão global de mundo e serem capazes de enfrentar os problemas complexos, amplos e globais da realidade atual.

\section{CA4 - Material de apoio utilizado}

Quanto ao uso de diferentes materiais de apoio destacaram que os materiais proporcionaram a reflexão sobre a mudança de metodologias. Todos os professores possuíam os materiais, contribuindo para a formação continuada em serviço. Dentre os materiais disponibilizados, os professores apontaram que o material impresso possibilitou leituras em grupo, seguidos de discussões que contribuíram para que o grupo refletisse sobre assuntos que fazem parte do cotidiano da escola e, ainda, temas relacionados com as características dos alunos do Ensino Médio, favorecendo assim o enriquecimento da equipe.

O CD com entrevista e ou argumentações, demonstrando as idéias centrais de alguns teóricos, possibilitou articular teoria com a prática, porque trouxe para o centro das discussões assuntos que retratavam o dia-a-dia do professor numa ação dialógica, constituindo um elemento da linguagem e da consciência ideológica.

Os conteúdos estudados, analisados, discutidos nos encontros, eram aplicados em sala de aula pelos professores. No início, alguns professores ficaram resistentes pois acreditavam que estavam deixando seus conteúdos de lado para trabalharem novos conteúdos, entretanto foram, aos poucos, 
percebendo a intencionalidade das ações, foram acreditando e elaborando projetos em parceria com outros professores e internalizando o processo.

Em cada encontro, os professores evidenciavam interesse nos temas, nos textos desenvolvidos e analisados. Os conhecimentos foram socializados e compartilhados, ocorrendo intensa troca de experiências pois segundo Imbernón ( 2001, p. 72):

A formação permanente deve ajudar os professores a desenvolver um conhecimento profissional que lhe permita: avaliar a necessidade potencial e a qualidade da inovação educativa que deve ser introduzida constantemente nas instituições;desenvolver habilidades básicas no âmbito das estratégias de ensino em um contexto determinado,[...];proporcionar as competências para ser capazes de modificar as tarefas educativas continuamente.

\section{CA5 - Mudança de concepção ou metodologia}

Em relação à mudança de concepção ou metodologia apontaram que: "Não será possível continuar trabalhando como estávamos" ( $P$ 6). Há necessidade de se fazer modificações, porém, para que haja mudança de concepção, precisam de tempo para internalizar, estabilizar para depois modificar.

concepção:

Miranda (2007, p.3) nos faz refletir que em se tratando de mudança de

A centralidade do conhecimento (da informação, da produção do conhecimento e de sua difusão) e a implícita mudança da concepção de conhecimento parece ser uma idéia para a qual convergem todos os discursos, todas as propostas, todos os chamados atores sociais. Afinal, quem poderia negar que o impacto da globalização associado ä revolução tecnológica impõe um novo padrão de conhecimento: menos discursivo, mais operativo; menos particularizado, mais interativo, comunicativo; menos intelectivo, mais pragmático; menos setorizado, mais global; não apenas fortemente cognitivo, mas também valorativo e atitudinal.

Nesse sentido as mudanças de concepção serão percebidas ao longo do tempo. O conhecimento vai se construindo à medida que os professores 
vãos se sentindo à vontade, retomando algumas questões, concluindo dados, apresentando seus novos conhecimentos ao grupo, ou seja, reconstruindo sua prática pedagógica, uma vez que estão envolvidos nesse processo natural.

\section{CA 6 - Quais modificações fariam no Programa}

Ao serem argüidos sobre quais modificações fariam no Programa para melhorar o rendimento, apontaram que "Os temas abordados foram importantes, pertinentes e contextualizados, mas é necessário mais tempo para reflexão, debate e aprofundamento".

No espaço aberto para as considerações finais sobre o Programa e sua aplicação, percebemos que os professores valorizaram o incentivo à leitura e perceberam o aluno como protagonista. Contudo, alguns questionaram a aplicação do Programa durante o horário de HTPC, porque acreditam que nesse espaço há necessidade de discutir problemas e conquistas da escola. Consideram esse espaço como propício para troca de experiência e diálogo com outros professores da área.

Apontaram que das reflexões emergiram contribuições relevantes, assim como as interações sociais estabelecidas, que fortaleceram o grupo.

Após os conteúdos terem sido estudados, analisados e discutidos, elaboraram atividades interdisciplinarmente e aplicaram em sala de aula. Surpreenderam-se com a aceitação dos alunos e com a forma positiva com que reagiram, percebendo que o conhecimento não é estanque e sim inter-relacionado entre as diversas disciplinas. 


\section{CONSIDERAÇÕES FINAIS}

A mola propulsora para essa pesquisa consistiu em perceber a concepção que os educadores têm a respeito da formação continuada e a aplicabilidade de um Programa que se originou a partir da expectativa de contribuir para o avanço da educação no ensino médio no Estado de São Paulo, e que buscou contribuir com a formação continuada dos professores durante sua jornada de trabalho, enquanto uma das formas de formação continuada apresentava a educação diante da nova realidade social.

Esse programa que foi implantado no ano de 2004 e se estendeu até o ano de 2006, contou com uma organização que pretendeu formar os professores em base teórica e ao mesmo tempo produzir ações que iniciasse ou aprofundasse o diálogo entre as diversas áreas de conhecimento e entre as disciplinas, numa tentativa de um trabalho interdisciplinar.

As disciplinas no Ensino Médio, na maioria das vezes, apresentam-se de forma fragmentada e desarticulada e a aplicação desse Programa buscou jogar luzes sobre o trabalho interdisciplinar para aproximar as disciplinas.

Ao percorrer o longo caminho nessa pesquisa, obtivemos resultados importantes, quais sejam que a formação continuada coletiva é de relevante importância e necessária para o desenvolvimento profissional dos professores; a aplicação deste Programa proporcionou uma experiência de leitura, análise, inferência e aplicação de diversos gêneros de leituras por professores de diferentes áreas; contribuiu para que os professores percebessem a importância dos textos científicos em sala de aula, nas diversas disciplinas; contribuiu também para que os professores utilizassem diversos recursos tecnológicos como instrumento facilitador do processo ensino e aprendizagem.

Outro importante aspecto deu-se ao colocar os professores na situação de professor - pesquisador, caminho este que deveria ser trilhado por todos, para que a educação alcançasse qualidade. Os professores, ao se debruçarem sobre os textos teóricos, fizeram-no da maneira como saberiam que iriam aplicar os conhecimentos adquiridos, contribuindo para que a aplicabilidade do programa se 
efetivasse realmente.

Todo processo foi enriquecedor. Percebemos que um dos caminhos mais importantes no desenvolvimento do trabalho foi o compromisso dos professores em relação à aprendizagem dos alunos e à própria aprendizagem.

A participação dos docentes na realização de atividades no cotidiano que envolveu ações de cooperação, produção de projetos coletivos que envolveram a combinação de materiais, espaços, a reflexão de temas pertinentes, a valorização da leitura em todas as áreas, proporcionando o diálogo entre as diferentes disciplinas. Ao estabelecer este diálogo, o Programa favoreceu o conhecimento das múltiplas relações entre as áreas do conhecimento.

Das análises tecidas no trilhar desse trabalho, resultou-nos uma modesta conclusão que não se fecha em si, mas abre um amplo debate e caminhos para a formação contínua de professores.

Concluímos que há uma relação entre aprendizagem para ensinar e aprender e que a mudança de prática (o que objetiva toda formação) compreende uma complexidade de situações, ou seja, a formação inicial, a história individual, os conhecimentos prévios, o tempo de trabalho de cada um e a credibilidade na própria formação. A formação continuada precisa criar condições para que haja manifestações por parte dos formadores e dos professores que permitam a reflexão sobre a ação, com bases teóricas, e concordamos com Cró (1998, p.132) quando afirma que "No decurso da formação contínua, as estratégias escolhidas devem ser operacionalizadas, experimentadas e reguladas".

Como contribuição, consideramos que a formação continuada deve pautar-se em estratégias:

a) que redimensionem a situação dos professores para professor-pesquisador;

b) que articulem as necessidades dos professores com as do sistema, ou seja, que partam das necessidades prementes dos professores em consonância com as teorias educacionais;

c) que propiciem aplicação, análise e acompanhamento sistemático, onde a reflexão sobre a ação seja constante e realizada em conjunto com os professores;

d) que promovam a reflexão sobre a ação estabelecendo vínculo com a devolutiva, ou seja, que os formadores se debrucem sobre as produções dos professores para a 
reflexão em conjunto, buscando assim o crescimento da equipe;

e) que levem os formadores de opinião a fazer parte de uma equipe especializada, capaz de supervisionar os trabalhos e as ações constante e sistematicamente.

O Programa em seu desenvolvimento possibilitou aos professores das diferentes áreas de ensino oportunidades para exercitar suas habilidades em leituras de diversos gêneros, num movimento de análise das estruturas textuais, e contribuiu para que todos percebessem a importância da leitura e a exploração dos textos científicos na ação didático-pedagógica.

Uma das ações a que o Programa se propôs constituiu-se na elaboração de um BLOG ${ }^{11}$ para a divulgação das informações na rede de Internet. Para isso, tornou-se necessário um planejamento de ações sistemáticas, uma série de análises de diferentes tipos de textos, a inferência em outros e o refletir sobre cada ação, além de conhecimentos específicos, tecnológicos e científicos.

Cada escola, ao elaborar seu BLOG, possibilitará a divulgação de seu trabalho, num processo de integração. O Programa Ensino Médio em Rede, durante seu desenvolvimento, permitiu aos alunos e aos professores das diferentes áreas, não somente a leitura de diversos textos, mas a exploração e a construção de textos de diferentes áreas e também a compararem, explorarem, analisarem, inferirem, construírem e reconstruírem textos científicos, dentro de seus conteúdos.

Contribuiu para que os professores percebessem a estreita relação entre sua disciplina e as demais, mas também para que o aluno se tornasse leitor crítico e reflexivo.

A divulgação no BLOG permitirá a veiculação desses textos na mídia, o que exigirá conhecimentos específicos e teóricos.

Nesse sentido ao construírem textos, permitirá que os alunos tornemse protagonistas de seu próprio desenvolvimento.

A realização desse trabalho, que permitiu "ouvir a voz do professor", mostrou que a formação continuada mobiliza ações, estimula os professores e articula a teoria com a prática pedagógica. E essa articulação tão necessária precisa estar vinculada à reflexão na ação, a partir da ação e depois da ação.

11 Podemos definir o blog como uma página de internet atualizada constantemente e formada por pequenos parágrafos, organizada cronologicamente. Semelhante a uma página de notícias ou um jornal. Segue uma linha de tempo com um acontecimento após o outro. Os conteúdos e informações dos blogs se refere a uma grande quantidade de temas que vão desde diários, piadas, links, notícias, fofocas, fãclube, poesia, idéias, fotos e outras informações relacionadas a vida do blogger (pessoa que possui um weblogger). 


\section{REFERÊNCIAS BIBLIOGRÁFICAS}

ALARCÃO, I. Reflexão crítica sobre o pensamento de D. Schön e os programas de formação de professores. Revista da Faculdade de Educação, São Paulo, n. 22, jul./dez.1996.

ALMEIDA, M.E.B. Tecnologia na escola. 2001. Disponível em: <http://www.tvebrasil.com.br>. Acesso em: 02 set. 2007.

ALONSO, M (Org.). $O$ trabalho docente: teoria \& prática. São Paulo: Pioneira, 1999.

BARILLI, E. C. V. C. Formação continuada de professores - por quê? Como? E pra quê? Revista de Tecnologia Educacional. v. 26, n. 143, p.43, 1998.

BECKER, F. O que é Construtivismo. Disponível em:

<ww.crmariocovas.sp.gov.br/pdf/déias>. Acesso em: 20 fev. 2007.

BEDAQUE, P. Ensino de ciências e exclusão científica. Revista Idéia, São Paulo, v.4, n. 5, 2006.

BODGAN, R.; BIKLEN, S. Investigação qualitativa em educação. Porto: Portugal, 1986.

BRASIL. Lei de diretrizes e bases da educacional nacional. Lei $n^{\circ} 9.394$, de 20 de dezembro de 1996. Diário Oficial da União, Brasília, Distrito Federal, 23 de dezembro de 1996.

. Ministério da Educação e do Desporto - Secretaria de Ensino Fundamental

Parâmetros Curriculares Nacionais - Ciências Naturais - Primeiro e Segundo Ciclos, 1996.

A construção da proposta Pedagógica na escola. Planejamento 2000, São Paulo: SE/CENP, 2000.

BERG, D. N.; SMITH, K. K. The clinical demands of research methodos. The Self 
in Social Enquiry. Califórnia: Sage Publications, 1988.

BRZEZINSKI I. Notas sobre o currículo na formação de professores: teoria e prática. Brasília: Ed.UNB, 1994.

CANÁRIO, R. Educação de adultos: um campo e uma problemática. Lisboa: Educa, 2000.

CARVALHO, A. P. E.; GIL-PERES, D. Formação de professores de Ciências: tendências e inovações. São Paulo: Cortez Editora,1995.

CENP. Programa Ensino Médio em Rede. Disponível em:

<http://cenp.edunet.sp.gov.br/index.htm〉. Acesso em: 23 abr. 2005.

CHIZZOTTI, A. C. Pesquisa em ciências humanas e sociais. 2. ed. São Paulo: Cortez, 1995.

CORBETT, T. Contabilidade de ganhos: a nova contabilidade gerencial de acordo com a teoria das restrições. São Paulo: Nobel, 1997.

CRÓ, M. L. Formação inicial e contínua de professores e educadores.

Estratégias de intervenção. Porto, Portugal: Porto Editora,1998.

FERGUSON, M. The Aquarian Conspiracy. Los Angeles, CA: J. P. Tarcher, 1980.

FREIRE, M. Observação, registro, reflexão. Instrumentos metodológicos. 3. ed. São Paulo: [s. n.], 2003. (Série Seminários. Espaço pedagógico).

FREIRE, P. Pedagogia da autonomia: saberes necessários à prática educativa. São Paulo: Paz e Terra, 2001.

. Pedagogia do oprimido. 12. ed. Rio de Janeiro: Paz e Terra, 1983.

FUSARI, J. C. A educação do educador em serviço: treinamento de professores em questão. São Paulo: PUC, 1988. 

1990. (Org.). $O$ professor de $1^{\circ}$ grau: trabalho e formação. São Paulo: Loyola,

FUSARI, J. C. A formação continuada de professores no cotidiano da escola fundamental. São Paulo: FDE, 1992. (Série Idéias n. 12). Disponível em: $<w w w . c r m a r i o c o v a s . s p . g o v . b r / p d f / i d e i a s>$. Acesso em :19 nov.2006.

GATTI, B. A. Formação continuada de professores: a questão psicossocial. Jornal Cadernos de Pesquisa, v. 119, p. 191-204, 2003.

GARCÍA, C. M. Formação de professores: para uma mudança educativa. Porto Portugal: Porto, 1999.

HAGUETE, T. M. F. Metodologias qualitativas na sociologia. Petrópolis: Vozes, 1990.

HERNÁNDEZ, F. S. J. M. A formação a partir da experiência vivida. Revista Pátio, v. 10, n. 21. nov. 2006.

IMBERNÓN, F. Uma nova formação docente. Revista Pátio, v. 10, p. 28, jan. 2007.

Formação docente e profissional: formar-se para a mudança e a incerteza. São Paulo: Cortez, 2001.

INEP. Instituto Nacional de estudos e Pesquisas Anísio Teixeira. Disponível em: <www.inep.gov.br/internacional/pisa〉. Acesso em: 06 set. 2007.

INEP. Instituto Nacional de Estudos e Pesquisas Anísio Teixeira. Disponível em: «www.inep.gov.br/básica/saeb`acesso em 12 ago. 2006.

KUHN, T S. A estrutura das revoluções científicas. São Paulo: [s. n.], 1975.

LAKATOS, E. M.; MARCONI, M. A. Metodologia científica. São Paulo: Atlas, 1991.

LAVILLE, C.; DIONNE, J. A construção do saber: manual de metodologia da 
pesquisa em ciências humanas. Porto Alegre: Artmed, 1999.

LIMA, M. S. L. A formação contínua do professor nos caminhos e descaminhos do desenvolvimento profissional. 2001. Tese (Doutorado) - Faculdade de Educação, USP, São Paulo.

LOPES, A. C.; MACEDO, E. (Orgs.). Disciplina e integração curricular: história e política. Rio de Janeiro: DP\&A, 2002.

LÜCK, H. Pedagogia interdisciplinar: fundamentos teórico-metodológicos.

Petrópolis: Vozes, 1995.

LUCKESI, L. C. Planejamento e avaliação na escola: articulação e necessária determinação ideológica. Disponível em: <www.crmariocovas.com.br> . Acesso em: 18 maio 2006.

LUDKE, M.; ANDRÉ, M. E. D. A. Pesquisa em educação: abordagens qualitativas. São Paulo: EPU, 1986.

LÜDKE, M.; ANDRÉ, M. E. D. A. Pesquisa em educação: abordagens qualitativas. São Paulo: EPU, 1988.

MARIN, A. J. Educação continuada: Introdução a uma análise de termos e concepções. Cadernos Cedes. Campinas: Papirus, n. 36, p. 13-20, 1995.

MIRANDA, M. G. de. $O$ novo paradigma de conhecimento e as novas políticas educativas na América Latina. Disponível em: <www.educacaoonline.pro.br>. Acesso em:15 out. 2007.

MORELATTI, M. R. M.; SOUZA, L. H. G. Aprendizagem de conceitos geométricos pelo futuro professor das séries iniciais do Ensino Fundamental e as novas tecnologias. Educ. Rev., Curitiba, n. 8, jul./dez. 2006.

NEVES, C. M. C. A. Educação a distância e a formação de professores.

Disponível em: <www.tvebrasil.com.br/salto/boletins2002/ead/eadtxt1a.htm>. Acesso em: 20 jul. 2006. 
NISBET, J.; WATT, J. Case study: readguide 26 - guides in educational research. Nottingham: Univ. of Nottingham School of Education, 1978.

NÓVOA, A. (Org.). Os professores e a sua formação. Lisboa: Dom Quixote, 1999. 2002. A formação de professores e trabalho pedagógico. Lisboa: Educa,

PERRENOUD, P. Novas competências para ensinar. Porto Alegre: Artes Médicas, 2000.

PERRENOUD, P. A prática reflexiva no ofício do professor: profissionalização e razão pedagógica. Porto Alegre: Artmed, 2002.

PIMENTA, S. G.; GHEDIN, E. (Orgs.). Professor reflexivo no Brasil: gênese e crítica de um conceito. São Paulo: Cortez, 2002.

RALSTON, A. T. Parceria pública e privada para uma educação melhor. In: Liderança, Gestão e Tecnologias: para a melhoria da Educação no Brasil. São Paulo: Copyright. PUC-SP, 2006.

RIBEIRO, A. I. M. Subsídios para a história de Presidente Prudente:as primeiras instituições escolares. São Paulo: Cliper, 1999.

RIOS, T. A. Significado e pressupostos do projeto pedagógico. São Paulo: FDE, 1992. (Série Idéias, n.15).

RODRIGUES, A.; ESTEVES, M. A análise de necessidade na formação de professores. Porto: Porto Editora, 1993.

SANTOS, $\mathrm{N}$ dos. Educação à distância e as novas tecnologias de informação e aprendizagem. Disponível em:

<http://www.engenheiro2001.org.br/programas/980201a2.htm>. Acesso em: 03 jul. 2007.

SCHÖN, D. Formar professores como profissionais reflexivos. In: NÓVOA (Org.). Os professores e sua formação. Lisboa: Dom Quixote, 1992. 
SCRIVEN, M. The methodology of evaluation. American Educational Research Association Monograph series on curriculum evaluation. Chicago: Rand Mcnally, v. 1, p. 39-83, 1967. Disponível em: <www.seade.gov.br/perfil>. Acesso em: 25 nov. 2006.

SÃO PAULO. Secretaria de Estado da Educação de São Paulo. Ensino Médio em Rede. Programa de Formação Continuada. CENP. 2004.

SOARES, M. B. O que é letramento. Diário do Grande ABC. 2003. Disponível em: $<w w w$. diarionaescola.com.br>. Acesso em: 28 ago.2007.

TRIVIÑOS, A. N. S. Introdução à pesquisa em ciências sociais: a pesquisa qualitativa em educação. São Paulo: Atlas, 1995.

VALENTE, J. A. A construção das escolas de amanhã. Revista Pedagógica Pátio. Porto Alegre: Artmed, 2006.

VASCONCELLOS, C. S. Para onde vai o Professor? Resgate do professor como sujeito de transformação. São Paulo: Libertad, 1995. (Coleção Subsídios Pedagógicos do Libertad; v. 1).

VASCONCELOS, M. L. M. C. A formação do professor no ensino superior. 2. ed. São Paulo: Pioneira, 2000.

WEISS. M. L. L. Psicopedagogia clínica: uma visão diagnóstica dos problemas de aprendizagem escolar. 5. ed. Rio de Janeiro: DP\&A, 1999.

YIN, K. R. Estudo de caso: planejamento e métodos. 2. ed. Porto Alegre: [s.n.] 2001.

ZEICHNER, K. M. A formação reflexiva de professores: idéias e. práticas. Lisboa: Educa, 1983. 
ANEXOS 
ANEXO 1

Tabela 1 - Desempenho médio na parte objetiva da prova do Enem 2006, por situação em relação ao Ensino Médio e tipo de escola que cursou, segundo a Região e Unidade da Federação

Total

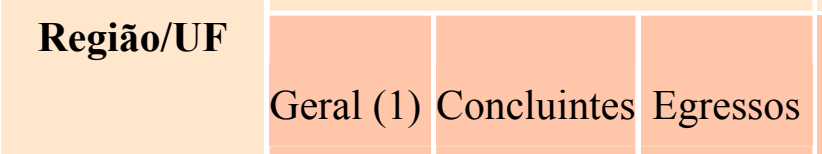

Tipo de escola em que cursou o Ensino Médio

Somente em escola pública
Somente em escola particular

\begin{tabular}{|c|c|c|c|c|c|}
\hline Brasil & $\mathbf{3 6 , 9 0}$ & $\mathbf{3 5 , 5 2}$ & $\mathbf{3 8 , 1 4}$ & $\mathbf{3 4 , 9 4}$ & $\mathbf{5 0 , 5 7}$ \\
\hline Norte & $\mathbf{3 2 , 1 7}$ & $\mathbf{3 1 , 0 5}$ & $\mathbf{3 3 , 5 0}$ & $\mathbf{3 1 , 4 8}$ & $\mathbf{4 2 , 7 9}$ \\
\hline Rondônia & 32,68 & 31,93 & 33,09 & 32,33 & 41,88 \\
\hline Acre & 31,05 & 30,66 & 32,31 & 30,27 & 41,35 \\
\hline Amazonas & 30,85 & 29,88 & 32,15 & 30,65 & 40,38 \\
\hline Roraima & 31,40 & 30,36 & 32,29 & 31,43 & 37,65 \\
\hline Pará & 33,13 & 31,78 & 34,74 & 32,07 & 44,09 \\
\hline Amapá & 31,44 & 30,16 & 33,20 & 31,20 & 38,42 \\
\hline Tocantins & 30,76 & 30,17 & 32,03 & 29,96 & 42,51 \\
\hline
\end{tabular}

\begin{tabular}{|c|c|c|c|c|c|}
\hline Nordeste & $\mathbf{3 3 , 8 3}$ & $\mathbf{3 2 , 6 8}$ & $\mathbf{3 4 , 9 3}$ & $\mathbf{3 2 , 3 9}$ & $\mathbf{4 6 , 4 4}$ \\
\hline Maranhão & 31,35 & 30,21 & 33,02 & 31,00 & 37,57 \\
\hline Piauí & 33,15 & 32,33 & 34,23 & 31,57 & 44,12 \\
\hline Ceará & 34,74 & 33,39 & 36,52 & 33,08 & 45,57 \\
\hline R. G. do Norte & 34,20 & 33,48 & 34,94 & 32,71 & 46,51 \\
\hline Paraíba & 33,66 & 32,76 & 34,87 & 32,16 & 45,45 \\
\hline Pernambuco & 35,97 & 34,56 & 37,47 & 32,98 & 47,90 \\
\hline
\end{tabular}




\begin{tabular}{|c|c|c|c|c|c|}
\hline Alagoas & 32,32 & 31,46 & 33,85 & 31,28 & 41,31 \\
\hline Sergipe & 33,52 & 32,95 & 34,47 & 32,17 & 49,11 \\
\hline Bahia & 33,27 & 32,04 & 34,04 & 32,33 & 47,16 \\
\hline Sudeste & $\mathbf{3 8 , 8 5}$ & $\mathbf{3 7 , 0 4}$ & $\mathbf{4 0 , 2 4}$ & $\mathbf{3 6 , 3 5}$ & $\mathbf{5 2 , 7 5}$ \\
\hline Minas Gerais & 39,03 & 37,73 & 40,13 & 37,34 & 53,36 \\
\hline Espírito Santo & 38,51 & 37,47 & 39,12 & 35,91 & 50,68 \\
\hline Rio de Janeiro & 38,61 & 37,78 & 39,54 & 35,88 & 49,16 \\
\hline São Paulo & 38,86 & 36,49 & 40,51 & 36,00 & 53,97 \\
\hline Sul & $\mathbf{3 8 , 7 3}$ & $\mathbf{3 7 , 6 2}$ & $\mathbf{4 0 , 0 8}$ & $\mathbf{3 7 , 4 1}$ & $\mathbf{4 9 , 8 5}$ \\
\hline Paraná & 38,07 & 37,30 & 39,01 & 36,28 & 52,30 \\
\hline Ranta Catarina & 37,83 & 37,24 & 41,13 & 35,91 & 48,98 \\
\hline G. do Sul & 39,63 & 38,20 & 40,86 & 39,29 & 45,77 \\
\hline
\end{tabular}

\begin{tabular}{|c|c|c|c|c|c|}
\hline Centro-Oeste & $\mathbf{3 5 , 4 5}$ & $\mathbf{3 4 , 7 3}$ & $\mathbf{3 6 , 2 7}$ & $\mathbf{3 3 , 9 7}$ & $\mathbf{4 8 , 4 7}$ \\
\hline M. G. do Sul & 34,84 & 33,94 & 35,37 & 33,65 & 44,22 \\
\hline Mato Grosso & 33,91 & 33,35 & 34,46 & 32,44 & 45,36 \\
\hline Goiás & 35,48 & 34,43 & 37,33 & 33,66 & 51,54 \\
\hline Distrito Federal & 37,96 & 38,47 & 37,76 & 36,77 & 51,62 \\
\hline
\end{tabular}

Fonte:INEP-Instituto Nacional de Estudos e Pesquisas Anísio Teixeira 


\section{ANEXO 2}

Tabela 2 - Desempenho médio na redação do Enem 2006, por situação em relação ao Ensino Médio e tipo de escola que cursou, segundo a Região e Unidade da Federação

\begin{tabular}{|c|c|c|c|c|c|}
\hline \multirow[b]{2}{*}{ Região/UF } & \multicolumn{3}{|c|}{ Total } & \multicolumn{2}{|c|}{$\begin{array}{c}\text { Tipo de escola em que cursou o } \\
\text { Ensino Médio }\end{array}$} \\
\hline & Geral (1) & Concluintes & Egressos & $\begin{array}{l}\text { Somente } \\
\text { em escola } \\
\text { pública }\end{array}$ & $\begin{array}{l}\text { Somente em escola } \\
\text { particular }\end{array}$ \\
\hline Brasil & 52,08 & 50,72 & 53,40 & 51,23 & 59,77 \\
\hline Norte & 49,05 & 46,85 & 51,70 & 48,65 & 58,00 \\
\hline Rondônia & 49,18 & 48,47 & 49,64 & 48,99 & 57,47 \\
\hline Acre & 47,97 & 46,77 & 51,72 & 47,10 & 60,31 \\
\hline Amazonas & 49,73 & 47,98 & 52,04 & 49,74 & 58,83 \\
\hline Roraima & 45,37 & 42,33 & 47,78 & 45,78 & 52,55 \\
\hline Pará & 49,78 & 46,81 & 53,12 & 49,13 & 58,49 \\
\hline Amapá & 50,00 & 47,68 & 53,43 & 50,20 & 55,94 \\
\hline Tocantins & 45,96 & 44,44 & 49,06 & 45,26 & 56,44 \\
\hline
\end{tabular}

\begin{tabular}{|c|r|r|r|r|r|}
\hline Nordeste & $\mathbf{5 0 , 9 2}$ & $\mathbf{4 8 , 8 0}$ & $\mathbf{5 2 , 8 3}$ & $\mathbf{5 0 , 1 6}$ & $\mathbf{5 9 , 4 9}$ \\
\hline Maranhão & 48,93 & 46,37 & 52,43 & 48,72 & 55,76 \\
\hline Piauí & 49,28 & 46,62 & 52,55 & 47,85 & 59,14 \\
\hline Ceará & 51,59 & 50,33 & 53,38 & 50,67 & 58,82 \\
\hline R. G. do Norte & 51,27 & 49,47 & 52,81 & 50,29 & 60,04 \\
\hline Paraíba & 49,99 & 48,30 & 52,31 & 49,06 & 58,50 \\
\hline Pernambuco & 51,10 & 49,22 & 52,82 & 49,84 & 58,24 \\
\hline
\end{tabular}




\begin{tabular}{|c|c|c|c|c|c|}
\hline Alagoas & 48,01 & 46,36 & 50,74 & 46,88 & 57,06 \\
\hline Sergipe & 48,98 & 47,40 & 51,08 & 48,05 & 60,42 \\
\hline Bahia & 51,53 & 49,25 & 53,02 & 51,02 & 61,74 \\
\hline
\end{tabular}

\begin{tabular}{|c|c|c|c|c|c|}
\hline Sudeste & 52,44 & 51,19 & 53,47 & 51,52 & 59,88 \\
\hline Minas Gerais & 53,06 & 51,81 & 54,13 & 52,36 & 60,29 \\
\hline Espírito Santo & 52,62 & 51,56 & 53,44 & 51,10 & 60,80 \\
\hline Rio de Janeiro & 53,34 & 52,38 & 54,60 & 51,73 & 60,86 \\
\hline São Paulo & 51,93 & 50,52 & 52,95 & 51,09 & 59,25 \\
\hline Sul & 55,29 & 54,61 & 56,16 & 54,72 & 60,59 \\
\hline Paraná & 53,77 & 53,14 & 54,58 & 53,13 & 60,16 \\
\hline Santa Catarina & 54,22 & 53,94 & 56,03 & 53,29 & 60,86 \\
\hline R. G. do Sul & 57,09 & 56,74 & 57,45 & 57,22 & 61,28 \\
\hline
\end{tabular}

\begin{tabular}{|r|r|r|r|r|r|}
\hline Centro-Oeste & $\mathbf{5 0 , 9 6}$ & $\mathbf{4 9 , 9 8}$ & $\mathbf{5 2 , 1 1}$ & $\mathbf{5 0 , 0 4}$ & $\mathbf{5 9 , 5 5}$ \\
\hline M. G. do Sul & 53,54 & 52,23 & 54,62 & 53,15 & 58,87 \\
\hline Mato Grosso & 47,96 & 47,40 & 48,57 & 46,85 & 57,32 \\
\hline Goiás & & 49,28 & 52,41 & 49,39 & 61,10 \\
\hline Distrito Federal & 52,74 & 52,80 & 52,88 & 52,39 & 60,43 \\
\hline
\end{tabular}

Nota: (1) Consideram-se todos os participantes independente da situação em relação ao Ensino Médio Observação: Os participantes são candidatos do Enem 2006 que fizeram a parte objetiva da prova Fonte: INEP- Instituto Nacional de Estudos e Pesquisas Educacionais Anísio Teixeira 


\section{ANEXO 3}

Questionário escrito, objetivando delinear o perfil do grupo em relação aos objetivos do Programa Ensino Média em Rede

\section{Escola Estadual Fernando Costa}

\section{Diretoria de Ensino de Presidente Prudente}

\section{Ensino Médio em Rede - Pesquisa}

O Programa Ensino Médio em Rede foi desenvolvido nesta escola e pretendo pesquisar sobre sua aplicabilidade. Para isso, torna-se necessário o conhecimento do perfil do educador e os avanços já ocorridos na escola em relação a sua aplicabilidade.

\section{Contamos com sua participação!}

Nome do professor

Disciplina (s)

Você participou em: 2004 ( ) 2005 ( )

Em 2006 haverá continuidade, você participará? ( ) sim ～～não

Tempo de serviço, como professor (aproximadamente)

Situação Funcional ( ) efetivo ( ) Estável ( ) ACT

1-Assinale quais motivos o levaram a se envolver com esse Programa:

( ) adquirir conhecimentos

( ) melhoria da qualidade do ensino 
( ) progressão funcional

( ) atualização

( ) fui influenciado por colegas

( ) fui influenciado pela coordenadora pedagógica

( ) aprender novas metodologias

( ) utilizar melhor as HTPCs

( ) outros. Justifique

2-De acordo com suas diretrizes o Programa Ensino Médio em Rede é um programa de formação de profissionais que atuam no ensino médio e deve subsidiar o professor para que ele, tendo em vista o projeto político-pedagógico de sua escola e as diretrizes gerais previstas em documentos oficiais, possa proceder a uma avaliação constante de seus alunos que sirva de parâmetro para seu planejamento diário. O Programa Ensino Médio em Rede está direcionado para alguns objetivos. Ao longo do ano como foram trabalhados:

3) Promover a discussão sobre as especificidades curriculares do Ensino Médio.

Como este objetivo tem sido trabalhado em seu grupo de estudos?

4) Esse Programa também propõe analisar criticamente a proposta pedagógica das escolas, orientar professores e planejar propostas de intervenção, tendo em vista o planejamento escolar, sobretudo no que diz respeito ao trabalho com compreensão e produção de textos. Este objetivo contempla um leque de possibilidades.

4.1 - Com relação à proposta pedagógica:
( ) ainda não foi analisada
( ) foi analisada

A proposta pedagógica foi analisada em quais aspectos?

5) Um outro objetivo do Programa ensino Médio em Rede diz respeito à desenvolver competências leitoras e escritoras dos agentes educacionais de Ensino Médio e fornecer subsídios para que os professores possam também desenvolver essas competências em seus alunos. 
Este objetivo tem favorecido ao que se propõe:
( ) muito
( ) razoavelmente
( ) pouco
( ) nada

\section{Justifique:}

5)..Promover a integração entre os professores das áreas, a partir de uma perspectiva interdisciplinar de discussão sobre projeto pedagógico:

A integração a que propõe está ocorrendo?
( ) $\operatorname{sim}$
( ) não
( ) em parte

7). Fortalecer as equipes escolares para dar suporte a mudanças na prática pedagógica:
( ) muito
( ) razoavelmente
( ) pouco
( ) nada

8). Possibilitar aos agentes educacionais o conhecimento e a utilização de novas tecnologias de comunicação e informação, através do uso de diversas mídias interativas, discutindo seus usos na continuidade da sua própria formação e na sua prática educativa.
( ) $\operatorname{sim}$
( ) não
( ) em parte

\section{Justifique:}

9) Este Programa se propõe a fazer uso dos ambientes de ensino e aprendizagem e as mídias e tecnologias da REDE DO SABER - teleconferências, videoconferências e web, além de materiais de apoio especialmente desenvolvidos para o programa.

O uso desse material:

( ) favorece a aprendizagem

( ) não foi possível utilizar 
( ) poderia ser melhor explorado

( ) alguns não foram utilizados.

Quais

( ) não contribui com a aprendizagem

( ) está sendo bem explorado, favorecendo a aquisição do conhecimento

10) Quais os benefícios que o Programa lhe ofereceu?

11) Faça os comentários que julgar necessário sobre o Programa e sua aplicação. Assinatura do professor: Data: 


\section{ANEXO 4}

\section{Entrevista}

Roteiro de entrevista

Nome do entrevistado

Cargo ou Função que exerce

Qual seu objetivo ao participar deste projeto?

1- Os objetivos do projeto Ensino Médio em rede estão claros para você?

2- Sentiu dificuldade(s) em algum momento?Qual (is)?

3- No formato do projeto contem momentos de leitura/reflexão sobre a prática/orientação e elaboração de atividades.

4- Qual(is) desse (s) momento (s) você tem mais facilidade?

5- Em qual (is) você tem mais dificuldade?

6- Em alguns momentos vocês precisam discutir idéias em grupo:

a- Qual sua opinião sobre esses momentos?

7- Qual (is) foi a maior contribuição que esse projeto trouxe para você?

8- O material de apoio tem contribuído ou não para sua formação continuada? Justifique

9- A partir deste projeto você mudará sua metodologia ou concepção sobre algum aspecto? Justifique

10- Houve aplicabilidade das atividades em sala de aula? Como?

11- O projeto procura refletir sobre a prática em sala de aula? Justifique

12- O que você mudaria neste projeto?

\section{Justifique:}


ANEXO 5

QUADROS SÍNTESES DE ACOMPANHAMENTO DO DESENVOLVIMENTO DO PROGRAMA 
QUADRO PARA ACOMPANHAMENTO SEMANAL DO PROFESSOR-COORDENADOR: TRABALHO COM ARTIGO DE OPINIÃO

Semana de 11 a 17 de outubro de 2006

\begin{tabular}{|c|c|c|c|c|c|}
\hline & $\begin{array}{l}\text { AÇÕES DOS } \\
\text { PROFESSORES }\end{array}$ & GRUPO 1 & $\begin{array}{l}\text { GRUPO } \\
2\end{array}$ & GRUPO 2 & GRUPO 3. \\
\hline A & Escolha do tema & $\begin{array}{l}\text { Engenharia } \\
\text { Genética_OK }\end{array}$ & & $\begin{array}{l}\begin{array}{l}\text { Não se } \\
\text { aplica }\end{array} \\
\end{array}$ & Nanotecnologia_OK \\
\hline $\mathbf{R}$ & Seleção dos textos & Ainda será feito & & $\begin{array}{l}\text { Não se } \\
\text { aplica }\end{array}$ & O mundo da tecnologia \\
\hline $\mathbf{T}$ & Planejamento & Ainda será feito & & \begin{tabular}{|l|} 
Não se \\
aplica
\end{tabular} & Ainda será feito \\
\hline I & das atividades de leitura & & & & \\
\hline G & definição da questão polêmica & & & & \\
\hline $\mathbf{0}$ & Definição dos textos de leitura & Ainda será feito & & $\begin{array}{l}\text { Não se } \\
\text { aplica }\end{array}$ & Ainda será feito \\
\hline \multirow[t]{2}{*}{$\mathbf{S}$} & e os locais para coleta de & & & & \\
\hline & de outros textos & & & & \\
\hline D & Orientação dos alunos & Ainda será feito & & $\begin{array}{l}\text { Não se } \\
\text { aplica }\end{array}$ & Ainda será feito \\
\hline \multirow[t]{2}{*}{$\mathbf{E}$} & para apesquisa & & & & \\
\hline & Planejamento de atividades & Ainda será feito & & \begin{tabular}{|l|}
$\begin{array}{l}\text { Não se } \\
\text { aplica }\end{array}$ \\
\end{tabular} & Ainda será feito \\
\hline $\mathbf{0}$ & de leitura & & & & \\
\hline \multirow{2}{*}{$\begin{array}{l}\mathbf{P} \\
\mathbf{I}\end{array}$} & Atividades de & Ainda será feito & & \begin{tabular}{|l|} 
Não se \\
aplica
\end{tabular} & Ainda será feito \\
\hline & acompanhamento & & & & \\
\hline \multirow{10}{*}{$\begin{array}{l}\mathbf{N} \\
\mathbf{I} \\
\hat{\mathbf{A}} \\
\mathbf{O}\end{array}$} & Orientação para elaboração & Ainda será feito & & $\begin{array}{l}\begin{array}{l}\text { Não se } \\
\text { aplica }\end{array} \\
\end{array}$ & Ainda será feito \\
\hline & de um quadro-síntese com & & & & \\
\hline & os argumentos favoráveis & & & & \\
\hline & e os contrários relativos & & & & \\
\hline & à questão polêmica & & & & \\
\hline & $\begin{array}{l}\text { Atividades para } \\
\text { amadurecimento }\end{array}$ & Ainda será feito & & \begin{tabular}{|l|} 
Não se \\
aplica
\end{tabular} & Ainda será feito \\
\hline & para a tomada de posição & & & & \\
\hline & pelos alunos & & & & \\
\hline & Avaliação do artigo produzido & Ainda será feito & & $\begin{array}{l}\text { Não se } \\
\text { aplica }\end{array}$ & Ainda será feito \\
\hline & nas aulas. & & & & \\
\hline
\end{tabular}


QUADRO 9

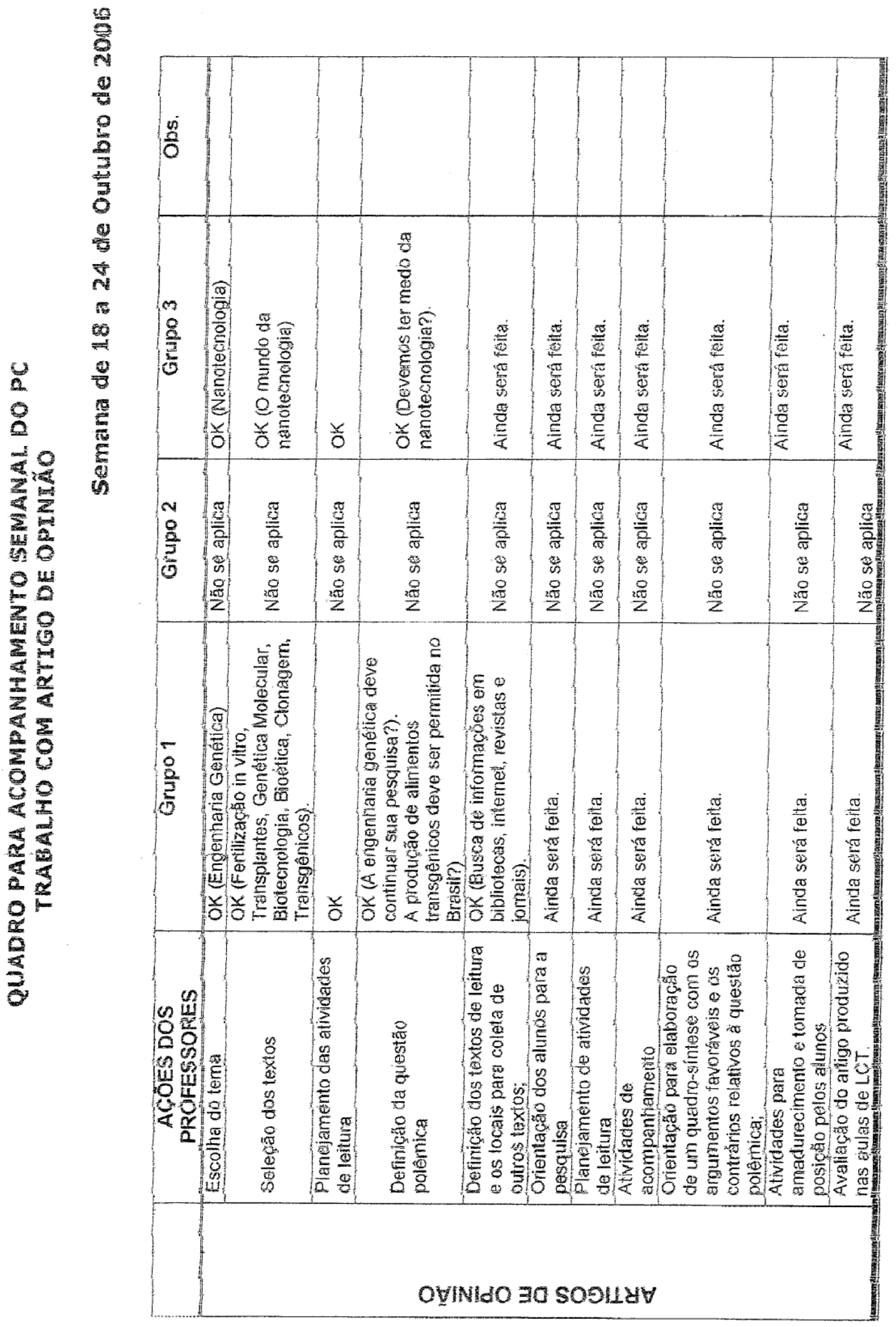


QUADRO 10

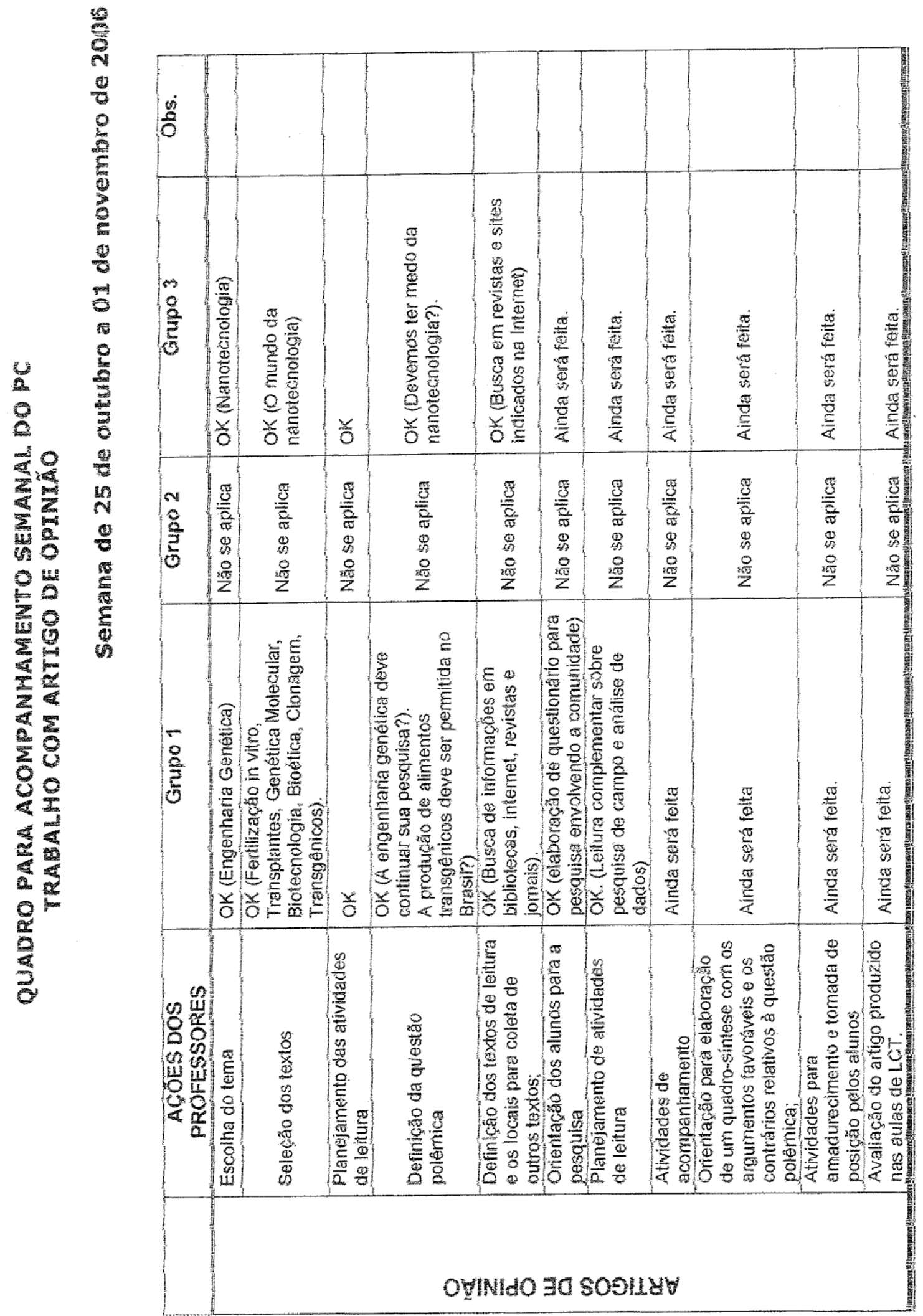




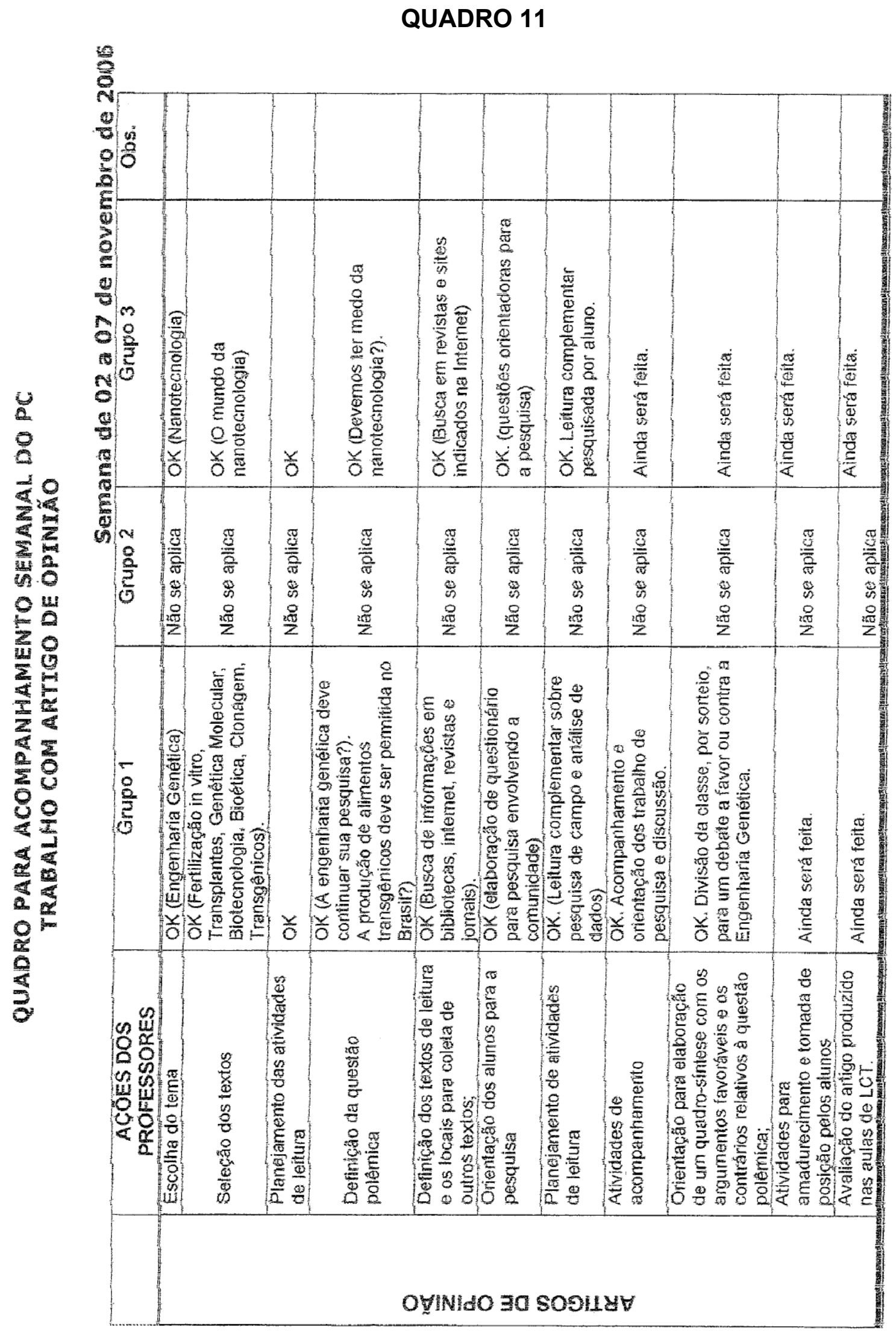


QUADRO 12

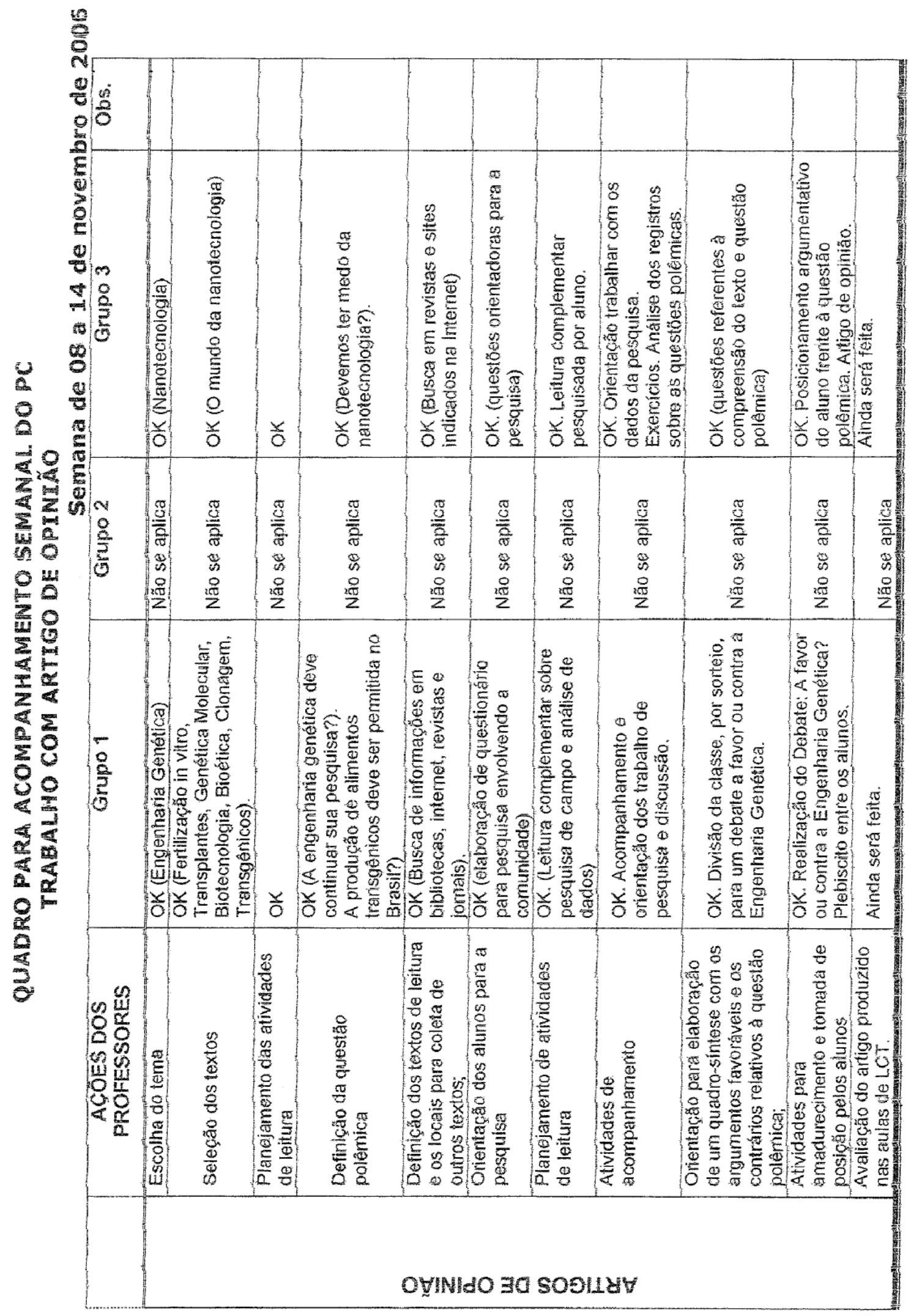




\section{QUADRO 13}

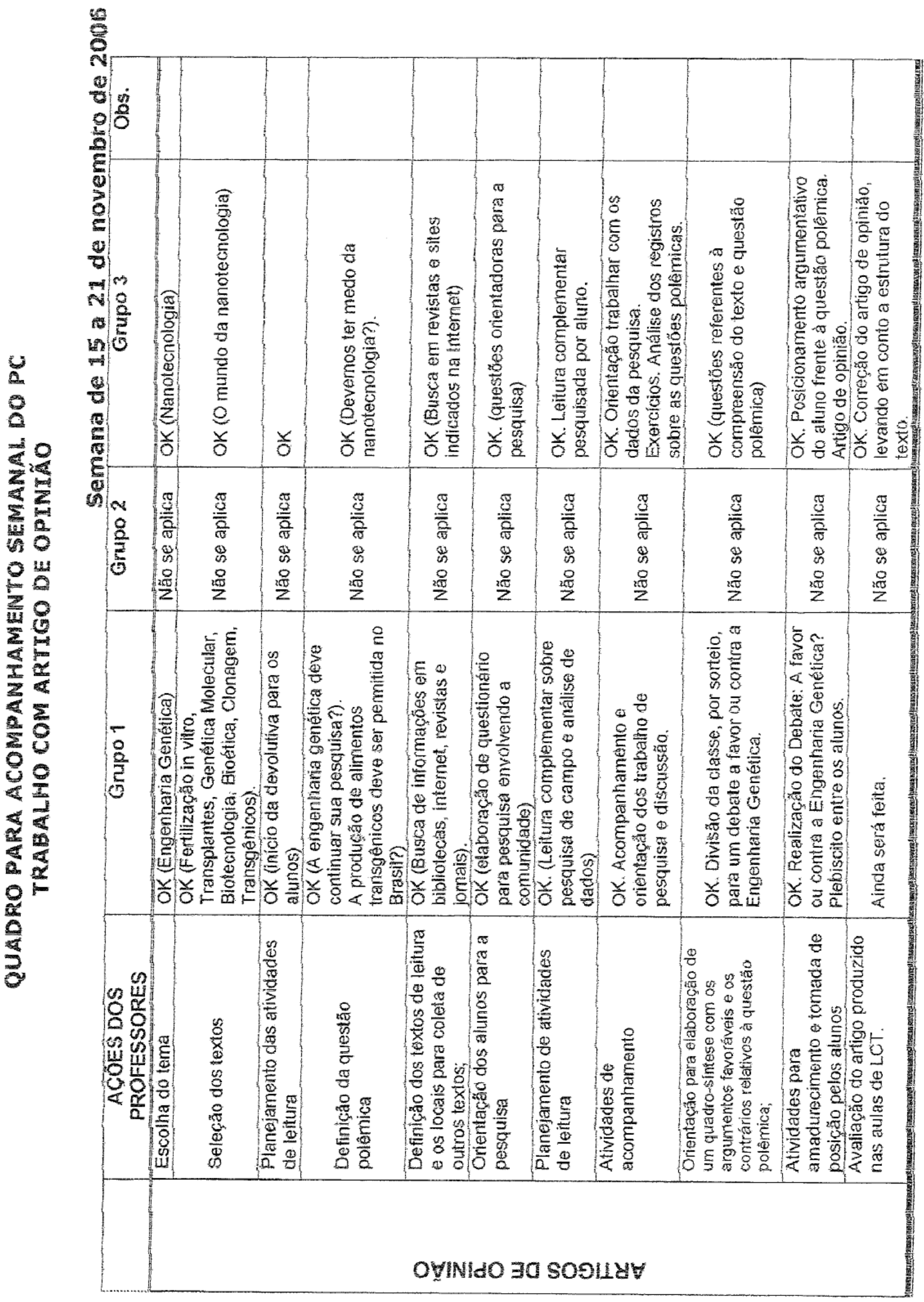


QUADRO 14

Quadro síntese de acompanhamento da Vivência Educadora :Tema 1

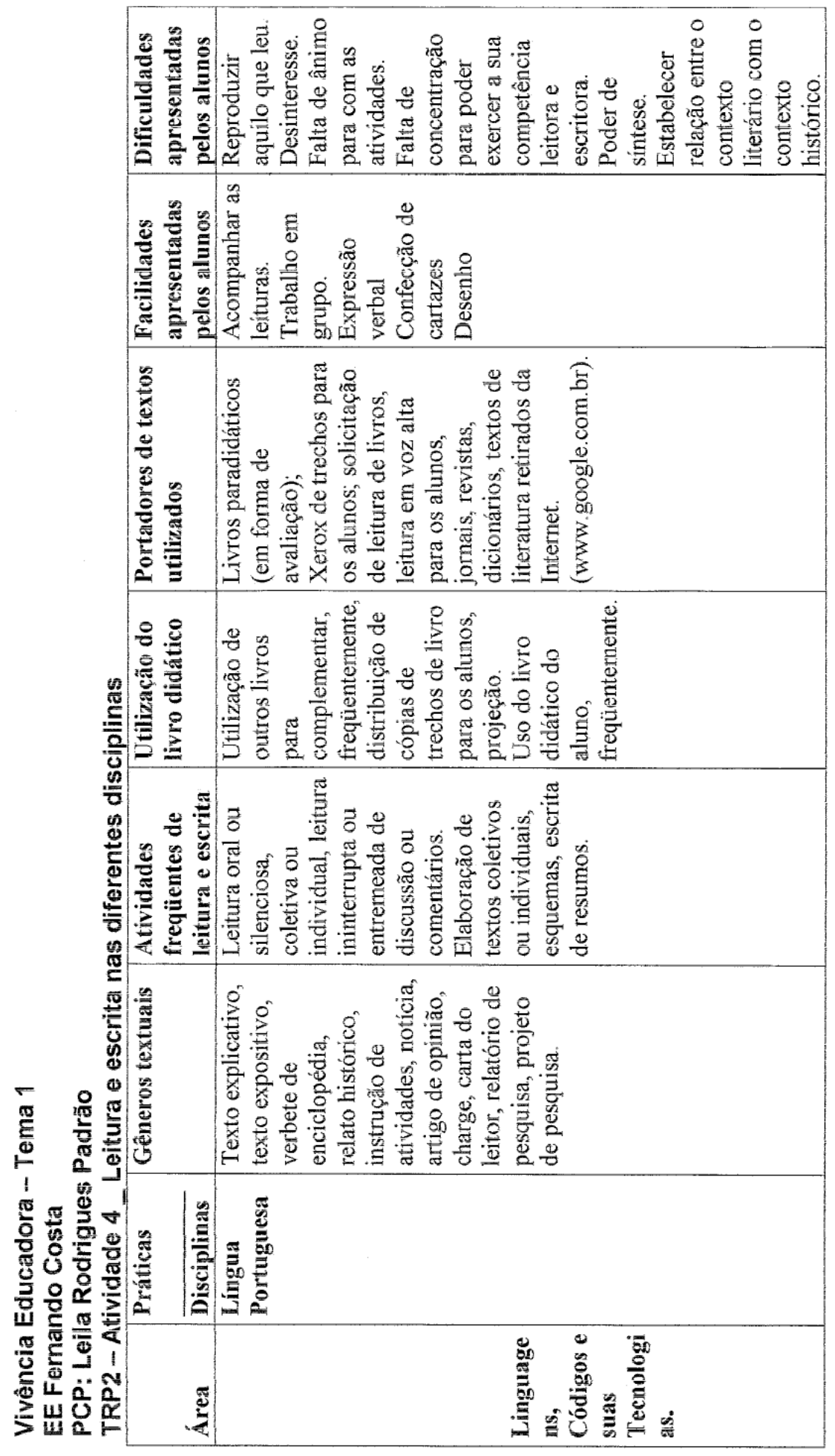




\begin{tabular}{|c|c|c|}
\hline & 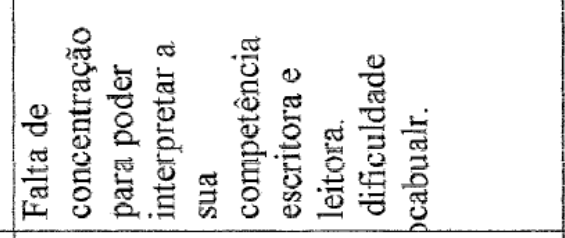 & 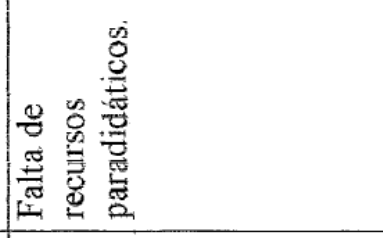 \\
\hline & 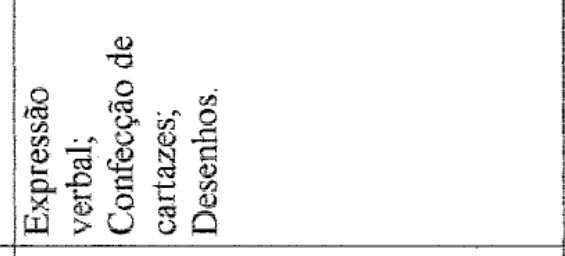 & 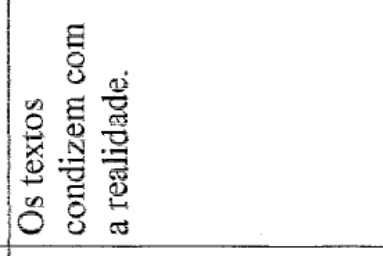 \\
\hline 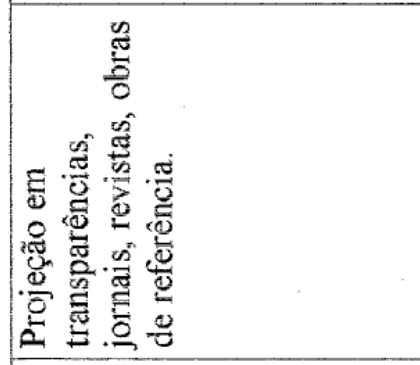 & 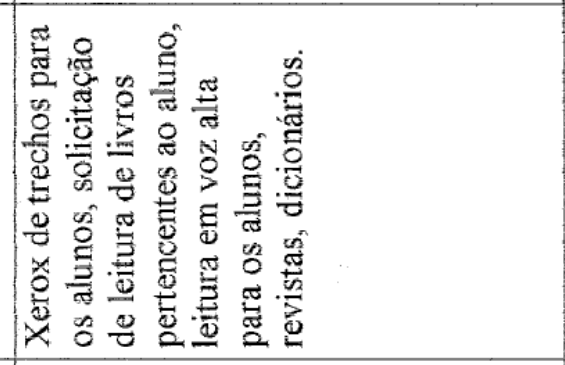 & 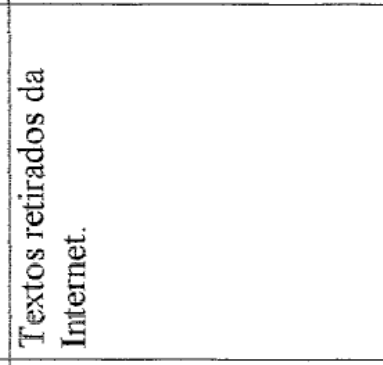 \\
\hline 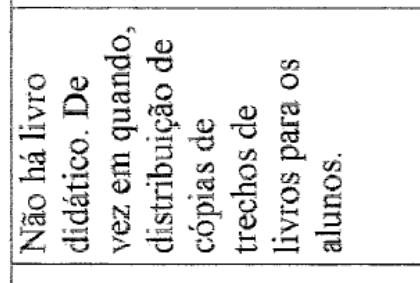 & 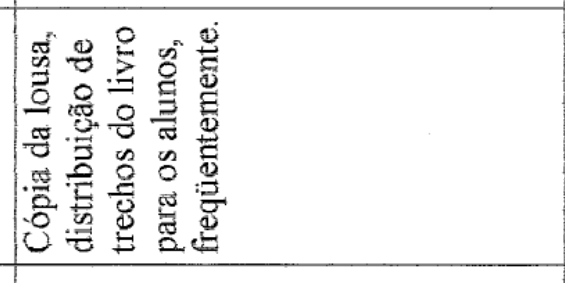 & \\
\hline 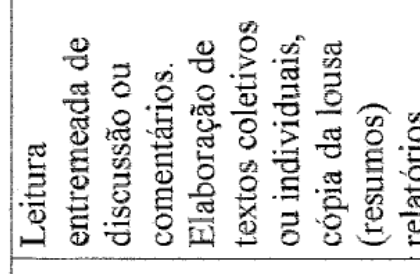 & 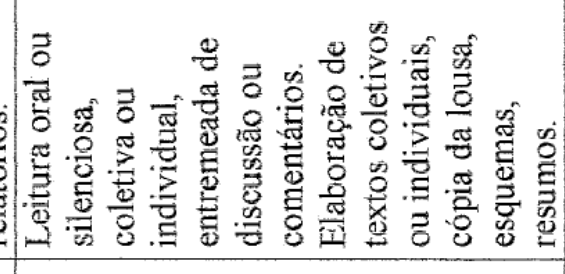 & 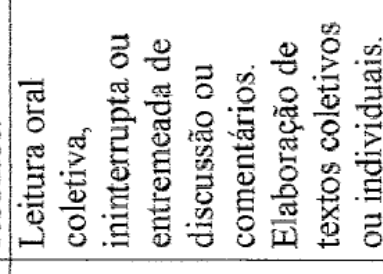 \\
\hline 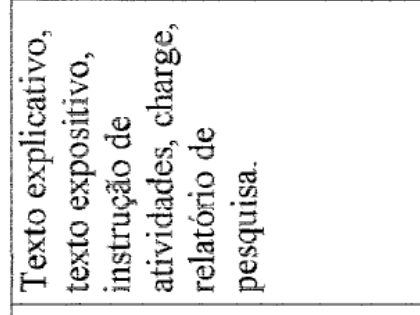 & 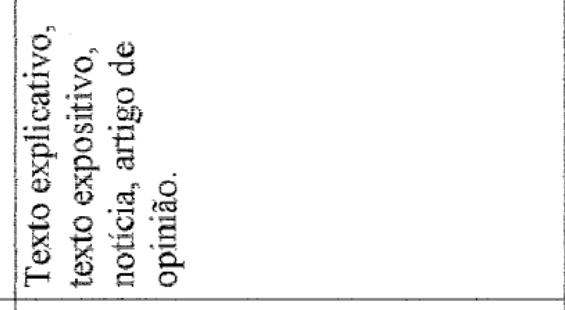 & 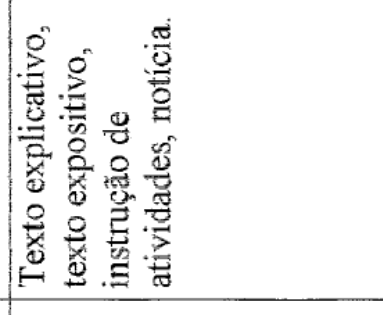 \\
\hline 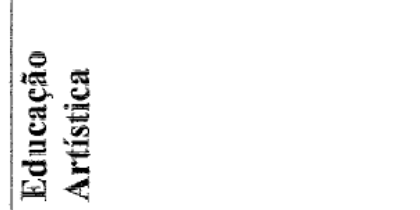 & 焉 & 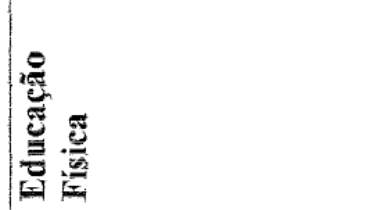 \\
\hline
\end{tabular}




\begin{tabular}{|c|c|}
\hline 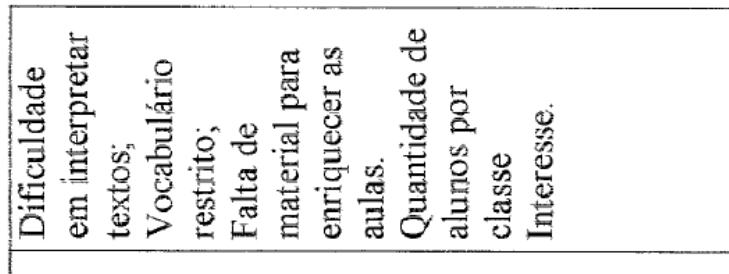 & 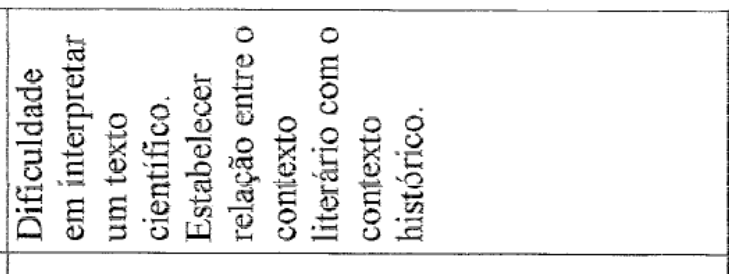 \\
\hline 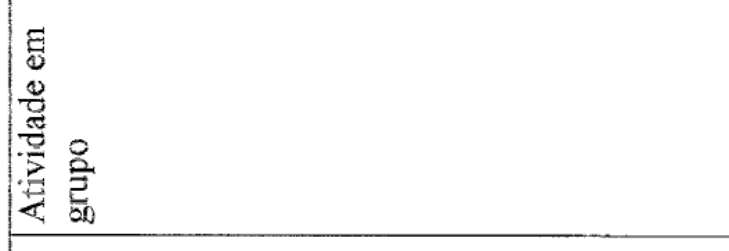 & 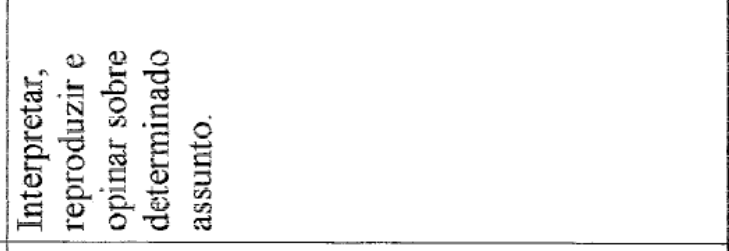 \\
\hline 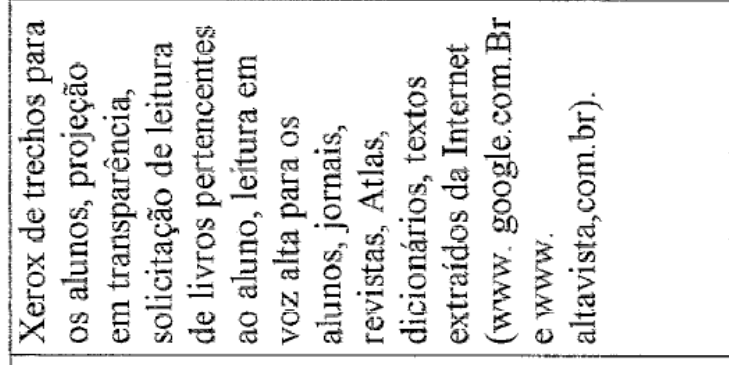 & 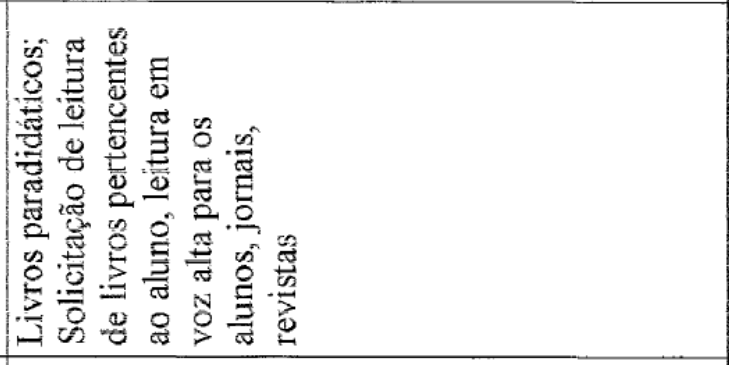 \\
\hline 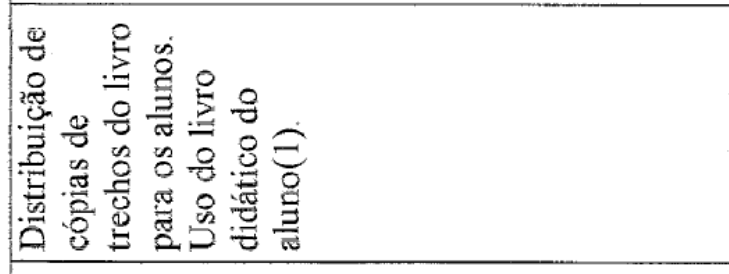 & 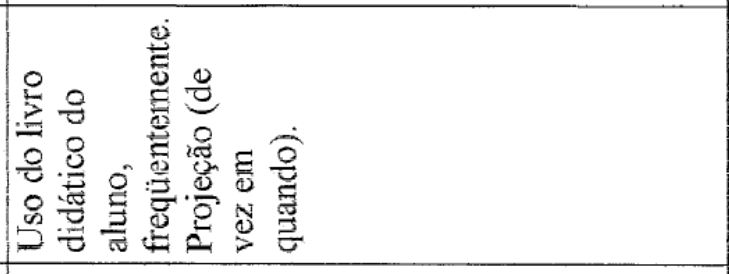 \\
\hline 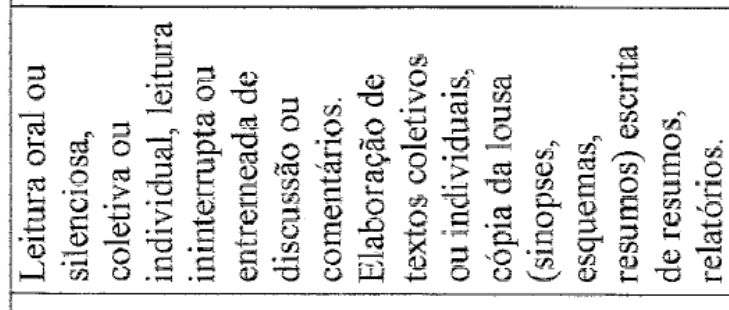 & 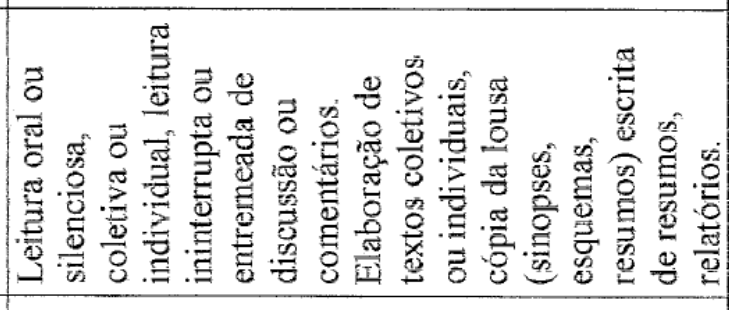 \\
\hline 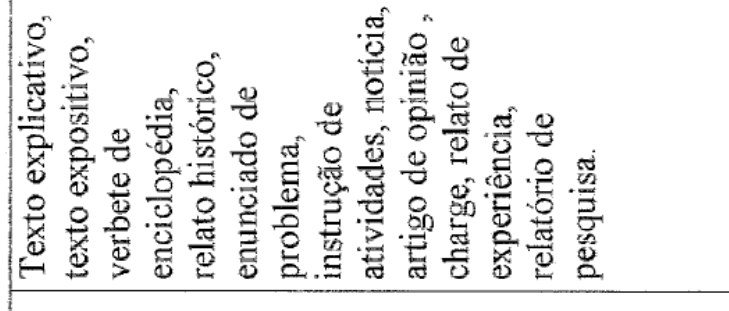 & 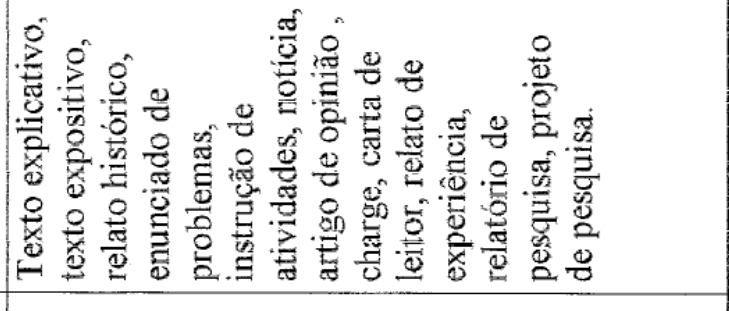 \\
\hline & \\
\hline & 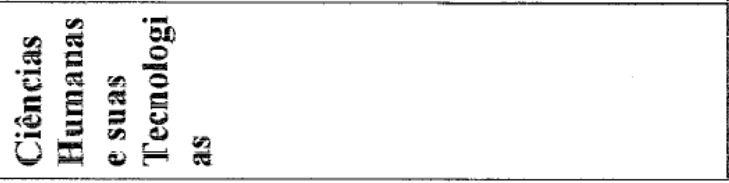 \\
\hline
\end{tabular}




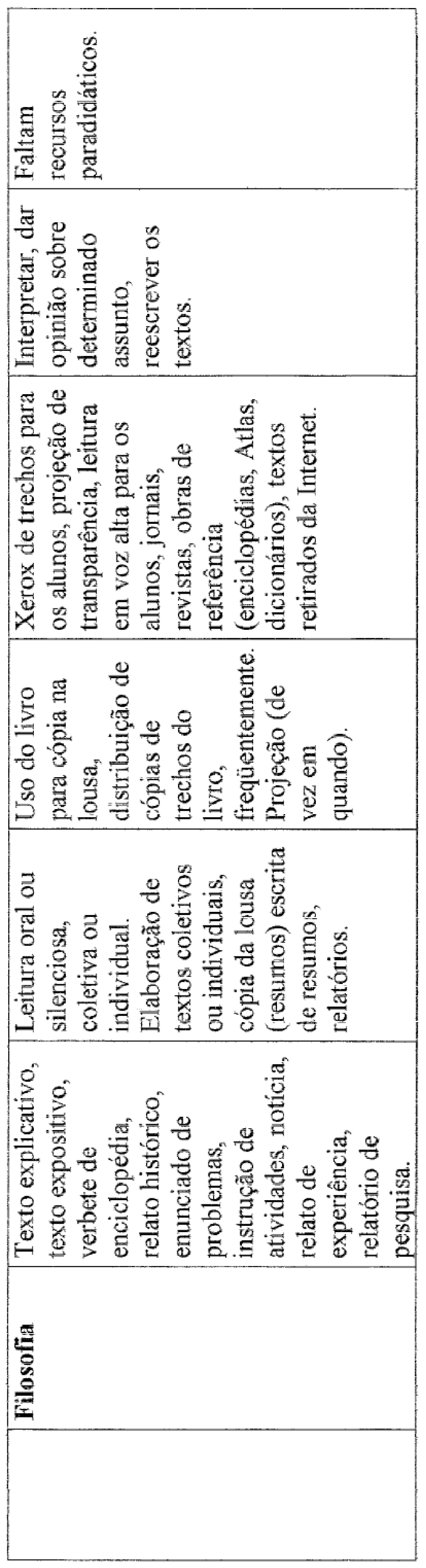




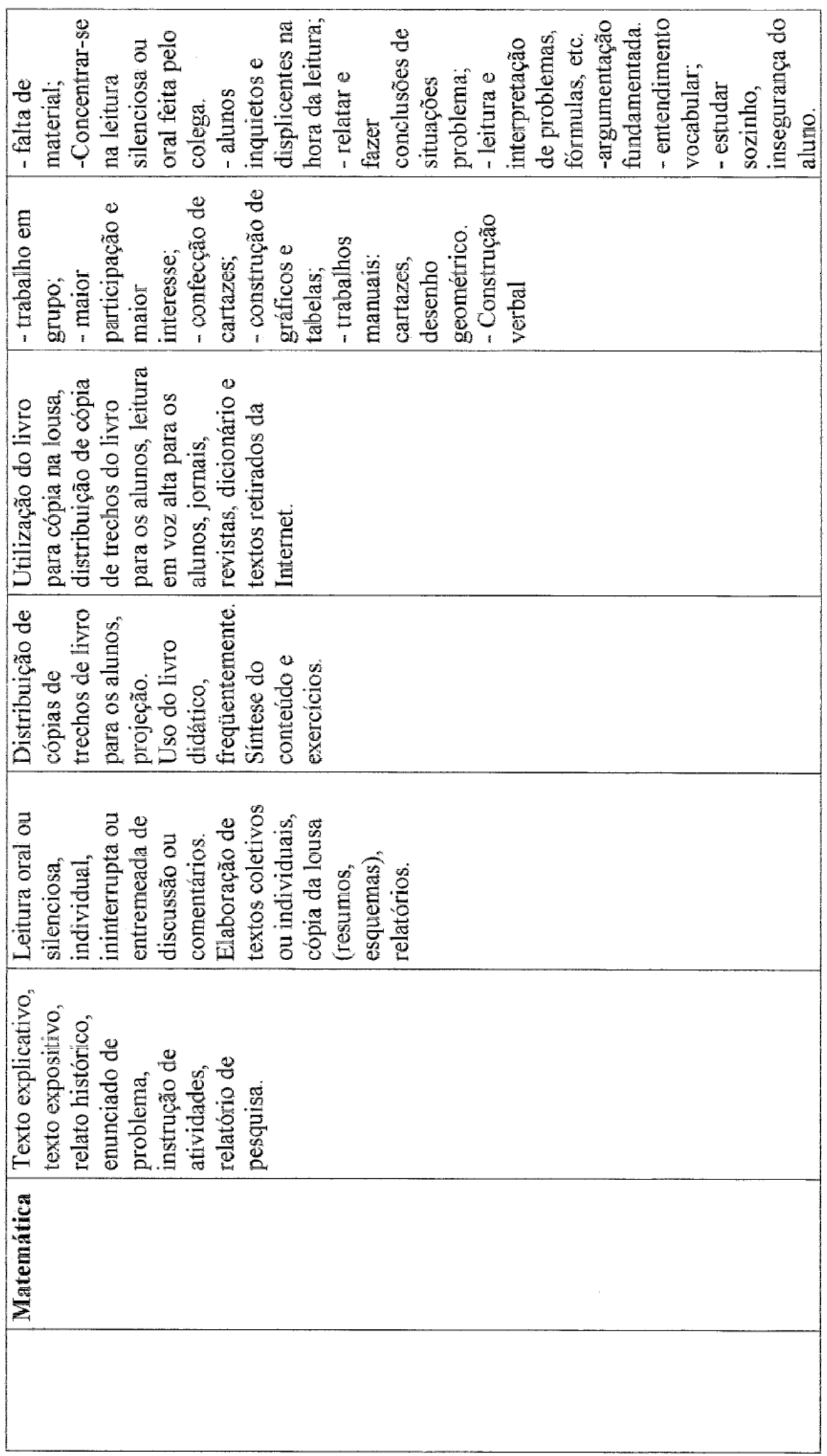


ANEXO 6

PLANOS DE AULAS DOCENTE 
PLANO DE AULA N ${ }^{\circ} 1$

E.E.FERNANDO COSTA

DISCIPLINAS: LÍNGUA PORTUGUESA, ARTE E FILOSOFIA

CLASSES: $1^{\circ} \mathrm{E} 2^{\circ}$ ANO ENSINO MÉDIO

TEMA: ÉTICA E CIDADANIA NA SOCIEDADE TECNOLÓGICA

JUSTIFICATIVA

A leitura como um processo de construção de significados em que o aluno vai interagir globalmente.

\section{OBJETIVOS}

Estimular o aluno a dominar a competência leitora, levando-o a refletir sobre o exercício da ética e da cidadania, descobrindo alternativas de vida para a busca da felicidade.

COMPETÊNCIAS A SEREM DESENVOLVIDAS

Capacidade de interpretação, reflexão...

COMPETÊNCIAS ESPEC ÍFICAS

Agregação de novos conceitos e ampliação da visão de mundo.

DESENVOLVIMENTO DA ATIVIDADE

- Problematização:

a) Por que muitos dos problemas que se nos apresentam são comparados com o 
"inverno"?

b) Por que o frio é comparado ao desamor e o quente (verão) com o amor?

c) É preciso que as pessoas desenvolvam e/ou cultivem um sentimento que devemos ter em relação a todos os problemas que enfrentam em nível local e global e às suas soluções.Como você modificaria essa situação que hoje se apresenta utilizando o texto?

d) Como entender a chamada "liturgia do texto" : " florescer pela manhã, mesmo se for nevar pela tarde"?

e) De que maneira o "frio" pode ser considerado também como situação de "aconchego"?

\title{
MATERIAL A SER UTILIZADO
}

Texto literário contemporâneo de Rubem Alves "A Árvore que florescia no inverno", inferências Bíblicas e a música "O que é o que é" de Gonzaguinha.

\section{DESENVOLVIMENTO}

Leitura do texto; coleta de impressões dos alunos sobre o texto; leitura de passagens bíblicas, levantamento de discussão sobre o texto (problematização).

\author{
AVALIAÇÃO \\ Resolução de questões propostas pelo texto \\ Produção de texto coletivo conclusivo \\ Participação nos diálogos \\ QUESTÕES
}

1- $\quad$ Que tipo de analogia você faz desse texto com a prática da vida 
real?

2- Descreva uma situação que exemplifique a proposição do texto de Rubem Alves.

3- Habacupe foi um profeta da Bíblia. Faça uma oração como ele contemplando os problemas e obstáculos que temos na atualidade e que, apesar deles, você continuará firme em seus propósitos e objetivos de vida.

4- Veja algumas afirmações do apóstolo Paulo e/ou da Bíblia, e faça um comentário transferindo para sua própria vida ou para a vida em sociedade.

5- $\quad$ Em sua opinião, quais os problemas que mais afligem a humanidade nos dias atuais?

6- Reúna seu grupo e faça uma encenação teatral sobre o texto, podendo extrapolar. 
PLANO DE AULA $N^{\circ} 2$

DISCIPLINAS : HISTÓRIA E FILOSOFIA

CLASSES: $2^{\circ}$ ANO DO ENSINO MÉDIO

PERÍODO NOTURNO

TEMA: TRABALHO ESCRAVO NO BRASIL NAS DIFERNTES ÉPOCAS POLÍTICAS E ECONÔMICAS

OBJETIVOS

Identificar os vários tipos de escravidão que já existiram e as que continuam nos dias de hoje

Reconhecer a distribuição de renda como geradora da injustiça social Conhecer as leis trabalhistas e saber reivindicar seus direitos.

JUSTIFICATIVA

Conscientização da importância do trabalho como meio de sobrevivência e dignidade.

\section{PROBLEMATIZAÇÃO}

As leis trabalhistas existem, mas é necessário conhece-las para cobra-las.

- Os movimentos sindicais como amprao aos direitos trabalhistas;

Os tipos de trabalho escravo nos dias de hoje;

- Segmentos da economia que mais utilizam o trabalho escravo.

DESENVOLVIMENTO DA ATIVIDADE

Leitura de textos jornalísticos e textos complementares sobre o traalho escravo no 
Brasil ( agronegócios e pecuária de ponta utilizam trabalho escravo)

-Declaração dos Direitos Humanos

- Leis trabalhistas da Constituição atual. ( Apostila elaborada pelo professor Pedro Gutierrez de Carvalho : págians 12,13,14,15,16,17 e 18).

\section{MATERIAIS A SEREM UTILIZADOS}

Textos jornalísticos

Outros

Plano de ação

Coleta de impressões sobre o texto;

Leitura de textos;

Identificação do gênero do discurso ( reportagem, artigo de opini9ão, crônica, editorial, etc);

Apresentação do ponto de vista explorado pelo autor nos diferentes textos;

Apreciação dos valores éticos, políticos, morais e sociais.

\section{AVALIAÇÃO}

Produção textual em grupo sobre " $O$ trabalho escravo no Brasil, suas implicações e possíveis soluções para acabar com essas práticas".

Explanação oral sobre o mesmo.

Exposição crítica do estudo sobre o tema explorado. 
PLANO DE AULA $n^{\circ} 3$

\section{DISCIPLINA: LÍNGUA PORTUGUESA}

CLASSES:2 ${ }^{\circ}$ ANO Ensino Médio

Período Manhã

Tema: Texto Literário (contemporâneo) - Ética e Cidadania na Sociedade Tecnológica

OBJETIVOS

Estimular o aluno a aluno a dominar a compet encia leitora, levando-o a refletir sobre os aspectos articuladores sobrw a ética e da cidadania, desobridno alternativas de vida para a busca da felicidade.

JSTIFICATIVA

A leitura como processo de construção de significados em que o aluno vai interagir globalmente.

COMPETÊNCIAS A SEREM DESENVOLVIDAS COM A ATIVIDADE

-Capacidade de interpretação e reflexão, e o estudo da gramática contextualizada (classificação morfológica das palçavras inseridas notexto)

COMPET WENCIAS GERAIS

Compreender e usar a Língua materna, geradora de significados e significação e da própria identidade. Recuperar, pelo estudo, as forma instituídas de construção do imaginário coletivo, o patrimônio representativo da cultura e as classificações preservadas e divulgadas, no eixo temporal e espacial.

\section{COMPETÊNCIAS ESPECÍFICAS}

Considerar a Língua Portuguesa como fonte de legitimação de ocorrido e condutas sociais, e como representação simbólica de experi encias humanas manifestas nas formas de sentir, pensar e agir na vida social.

ATIVIDADES A SERM DESENVOLVIDAS 
- Leitura de texto acompanhada de interpretação e reflexão;

Fita de vídeo: questões para refletir;

Música em CD.-“ O que é o que é” do autor Gonzaguinha;

Suporte textual: texto "As palavras têm sabor" de Josi Costa - leitura, interpretação e reflexão e análise lingüística;

Produção de redação dissertativa argumentativa;

Relações gramaticais:exercícios estruturais contextualizados.

PROBLEMATIZAÇÃO

Por que o autor do texto Rubem Alves se utiliza da seguinte frase de Alberto Camus:

"No meio do inverno, eu finalmente aprendi que havia dentro de mim um verão invencível".

Segundo as palavras do profeta Habacupe "... A despeito disso minha alegria continuará a florir/E farei procuras do impossível". Qual a intenção do autor ao fazer essa citação bíblica do referido profeta?

Diante de um mundo em que prevalece a mecanização, o desamor, qual a esperança do autor?Justifique com passagens do texto dado.

O que é mais realçado no texto:" as ações ou a vivência interior do personagem? Por quê?

\section{MATERIAL A SER UTILIZADO}

Texto literário contemporâneo de Rubem Alves e influências bíblicas: " $A$ árvore que florescia no inverno"

Fita de vídeo

Música

Texto suplementar "As palavras têm sabor!" de Josi Costa

\section{ESTRATÉGIA/ METODOLOGIAS}

Seleção de textos que motivem e propicie reflexões em outras áreas

Através da literatura e da redação procurar levar o aluno a refletir mais detidamente 
sobre sua condição existencial e sobre os aspectos da ética e cidadania (precedido de questionamentos, inferências e pontos de vistas do aluno)

Estudo gramatical a partir de textos compondo o equilíbrio entre a língua e a literatura(contextualização).

\section{AVALIAÇÃO}

Produção de redação dissertativa argumentativa, observando-se a coesão e coerência. 
Plano de aula $n^{\circ} 4$

\title{
PLANO DE AULA: DISCIPLINA MATEMÁTICA
}

\author{
Curso: Ensino Médio em Rede \\ EE Fernando Costa
}

Mediadora: Prof Coordenadora Pedagógica: Leila Rodrigues Powaso Professor: Tânia Regina Finheiro Sobottka

Série: $3^{\text {a }}$ séries A, B, C e D

Periodo: Agosto/ 5 aulas

\section{Temas:}

- Geometria plana

- Geometria espacial e métrica

\section{Objetivos:}

- Desenvolvimento das capacidades de leitura e escrita geométrica de figuras planas e espaciais; de obter, a partir de condiçőes dadas, soluçäo para problemas abordados; de analisar, relacionar, comparar, classificar, ordenar, sintetizar, avaliar a abstrair.

- Relacionar o avaliar o desonvolvimento tecnológico, bem como sua presença no mundo cotidiano e seus impactos na vida social.

\section{Justificativas:}

- Aprender a matemática de uma forma contextualizada e integrada a outros conhecimentos;

- Estimular os alunos para o estudo de objetos de formas planas e tridimensionais e suas representaçoes na forma de desenhos e planificações de objetos do mundo concreto;

- investigar as razóes do tamanho das embalagens de sabão em pó;

- Rofletir sobre as vantagens da escohna desses figurás geométricas.

Competências a serem desenvolvidas:

- Identificar, representar e utilizar o conhecimento geométrico para aperfeiçoamento da leitura, da compreensão e da ação sobre a realidade;

- Expressar-se com clareza, utilizando a linguagem matemática;

- Fomular questöes a partir de situaçóes reais e compreendei aquelas ja enunciadas;

- Elaborar estratégias de enfrentamento das questőes;

- Compreender e emitir juizos próprios sobre informações relativas a matemática;

- Elaborar comunicações orais ou escritas para relatar, analisar e sistematizar eventos, experimentos, correspondencia e questões;

- Aratisar, argumbntar oposicionar-so oriticamonto

\section{Competências específicas:}

- Reconhecer figuras pianas e figuras não planas;

- Identificar em um prisma seus elementos e classificáto;

- Reconhecer um paralelepípedo;

- Calcular a área da superficie lateral e da superficie total de um paralelepipedo; 
- Calcular o volume de um paralelepípedo;

- Calcular as dimensões do paralelepípedo para obter a área mínima.

Desenvolvimento da atividade:

Problematizaçâo: Vocês devem ter observado que vái ias marcas de sabão em pó tiveram mudança na embalagem de $1 \mathrm{~kg}$ : passaram de um paralelepípedo "mais estreito e alto" para um "mais largo e baixo"

Isso despertou curiosidade: teria sido o motivo puramente sstético ou houve intençäo das empresas de procurar menos custo para as embalagens dos produtos, uma vez que o custo incide diretamente sobres ibro thin?

Atividade: Embalagem (em anexo)

- Obsenvação das embalagens de sabão em pó antiga e atual, para que os alunos descrevam a figura geométrica;

- Levantamentos de hipóteses em relação às questões geradoras da atvidade;

- Elaboração de estratégias para o enfrentamento da questão, em pequenos grupos de alunos;

- Aplicação de métodos e procedimentos para o cálculo de volume e área das embalagens;

- Comparação dos resultados obtidos pelos grupos e socialização dos untêtos necessários para confeç̧ăo de embalagens para garantir a estética e o menor custo;

- Confecçăo de uma nova embalagem de sabão em pó, mantendo o mesmo volume (livre criação);

- Confecção de tabela com os dados obtidos no programa excel.

\section{Novo questionamento}

Considerando que a população do Brasil seja de aproximadamente 180 milhões de habitantes e, supondo que, um terço dessa população use uma caika de sabão por mês. Qual a economia de papelão por mês? Vocês já pensaram nisso? Calcular a economia de papeläo da caika antiga para a caika atual.

\section{Estratégia / Metodologia:}

- A resolução de problemas como peça central para o aprendizado da matemática, pois o pensar e o fazer se mobilizam e se desenvolvem quando o aluno está ativamente enfrentando desafios.

- As atividades serâo desenvolvidas em trabalho de grupo, pâre çie a interaça dos alunos desempenhe papel fundamental no desenvolvimento das capacidades cognitivas, afotivas $a$ do inscroüc social.

- A manipulação e confecção de material concreto (embalagens).

- A uso do computador, para auxiliar o processo de investigação de problemas matemáticos, facilitando os alunos de tarofas mais técnicas para permitir melhor gerenciamento do tempo das ações. 


\section{Avaliação:}

A avaliação será um processo constante durante toda a atividade. Os alunos serão avaliados através de observações, registros, produções, axeroloios, argumentaçöes $\theta$ relatos orais no desempenho individual e do grupo. desenvolvida.

Também pela elaboração de um relatório sobre a atividade

"Se realmente entendemos o problema, a resposta virá dele, porque a resposta não estó separadis do problema (Krishinamiritis) 
Agon, os calculos das áreas superficiais dos paralelepípedos, en cm?2

\begin{tabular}{|c|c|}
\hline 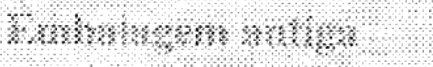 & 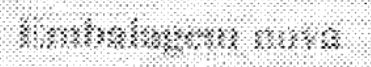 \\
\hline $24 \times 16.8 \times 2=806,40$ & $19 \times 14,5 \times 2=551$ \\
\hline $16,8 \times 4,8 \times 2=161,28$ & $19 \times 7 \times 2=266$ \\
\hline $4.6 \times 24 \times 2=230,40$ & $7 \times 14,5 \times 2=203$ \\
\hline TH:al $=1398,08 \mathrm{~cm}^{2}$ & Toral $=4020 \mathrm{~cm}^{2}$ \\
\hline
\end{tabular}

Binge? A caixa atual uilkza menos naterial para ser confeccionadia que a craka rativa.

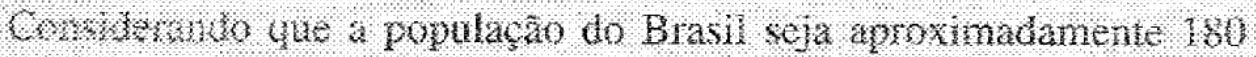

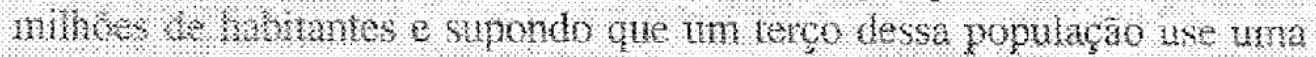

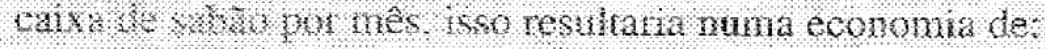

$608 \% .11013 \times(1,98,08-3020) \mathrm{cm}^{2}=10684800000 \mathrm{~cm}^{2}=$

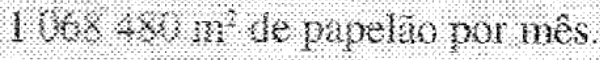

Voce 40 jarou para pensar nisso?

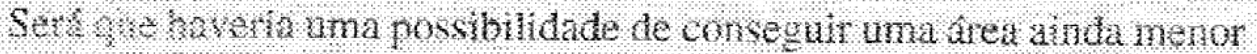

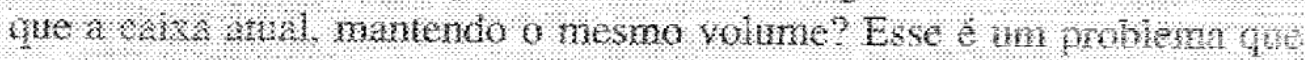
pode *: rewhido usando cálculo diterencial para determinar o ponto de

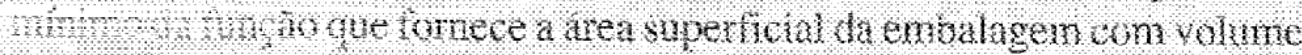

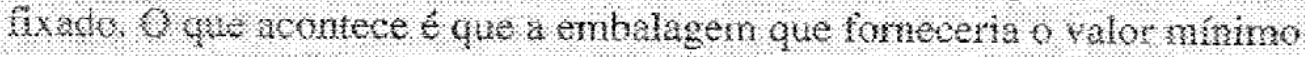
(um aror) no é apropriala pora ser manuseada; logo, as empresus tén que th -e? ina adaptacão entre o mínmo matemático e o prótico.

Pata una atividade em sala de aula. podemos, por temutrva, buscar a Grea superficial minima. fixando em $7 \mathrm{~cm}$ a medida latera da base st casxa, que julgamos adequaria an manusero.

Comsiaterando o volume da earka igral a $1928,5 \mathrm{~cm}^{2}$, dewouaxdo por c a outra dimensäo da base e por $h$ a altura da caixa, temos:

$$
h=\frac{1928,5}{7 c}
$$

A area superficial do paralelepípedo sera lukia por $A=2 \cdot 7 \cdot c+2 \cdot 7 \cdot h+2 \cdot c \cdot h$. e substitumido o valor de 4 na expressio obtenos: 


$$
\begin{aligned}
& A=14 c+14 \cdot \frac{1028,5}{7 c}+2 c\left(\frac{1928,5}{7 c}\right) \\
& A=14 c+\frac{385 t}{c}+55 t
\end{aligned}
$$

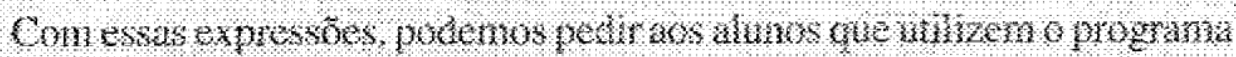

\begin{tabular}{|c|c|c|}
\hline 5 & 1392,4 & 55.3 \\
\hline \% & $1.1 \% \%, 00$ & $.4 \% 1 \%, 6 \%$ \\
\hline 7 & 1200 & $39,3571$. \\
\hline X. & $.3 \times 5.1 \% 2$ & $3.4 . \% \%$ \\
\hline 9. & 1105.556 & 30,611111 \\
\hline 14. & 10767 & $27.0 \%$ \\
\hline 11 & 1055.636 & $25.1315: 45$ \\
\hline $12:$ & 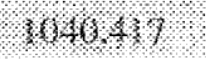 & 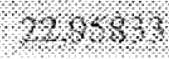 \\
\hline 13 & $1039.69 \%$ & $21 ., 19731$ \\
\hline 18 & 10.2 .2 .8 & $1 \%(13,8 \%$ \\
\hline 15 & 1638.133 & 18,36607 \\
\hline 16. & 161606063 & $(17.1 .1 \% \%$ \\
\hline $16{ }^{\circ}$ & $1 \% 15,753^{3}$ & 1668607 \\
\hline 17 & $401, .60 \%$ & 16,2086 \\
\hline 88 & 3817,278 & 15,30586 \\
\hline 14 & 1020 & 1.1 .5 \\
\hline 23 & 3023.85 & 13.713 \\
\hline
\end{tabular}
Excel pon construit a tabela abaixo.

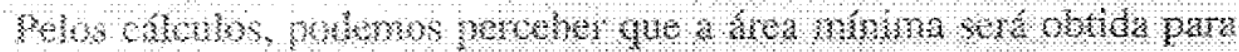

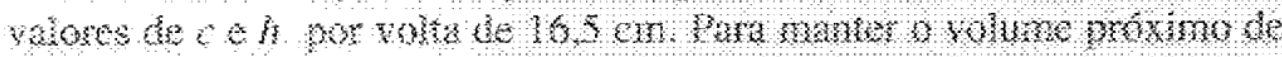
$3928,5,000$ knos $c=h-16,6$, botendo $\gamma-3928,92 \mathrm{r} A=1015.92$.

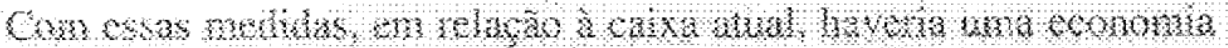
mensalab ano lgnal a

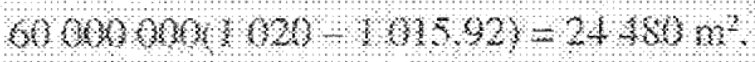


ANEXO 7

Produção de Alunos 
132

Produção de aluno $n^{\circ} 1$

E.E. Fernando Costa

220806

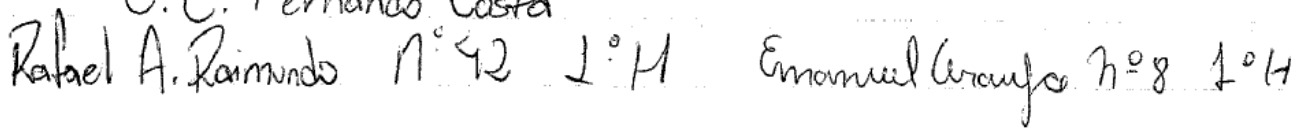

Atividade de EILOSOEIA

* Apás a leitura do texto" A árvore que Horescia no inverno (Rubem Alves), responda as questóes:

1) Que tipo de analogia vace far do texto com a vida real?

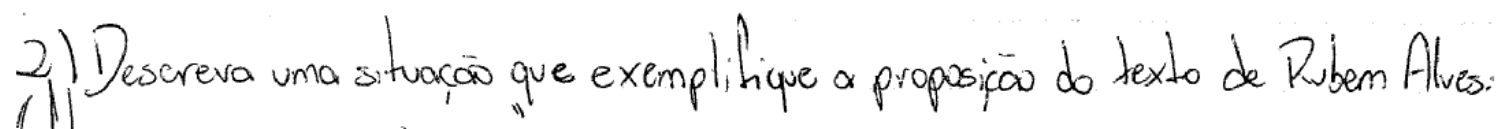
"Hovescer, mesmo no inverno".

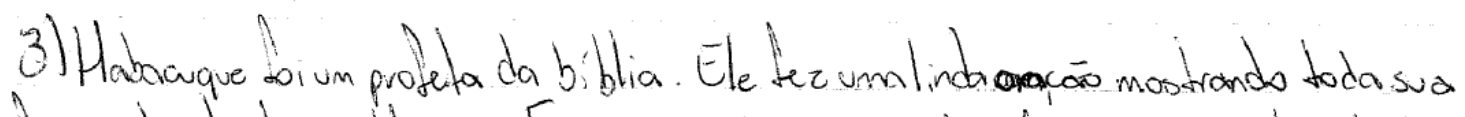
core a diante dos problemos. Focra una oraciá come ade Habacuque contemplondo os problemas e os obstáílos que temas no atualidade e que, apisar deles, vocié contirwará firme nas sews propósitos e obgetivos de vida.

4) Habacugue se fortalecev em meio a tantos problemas porque ele desenvolves um sentimento mui to importante quéé a Esperanca.

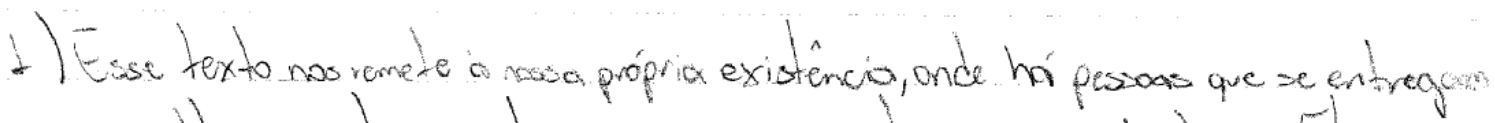

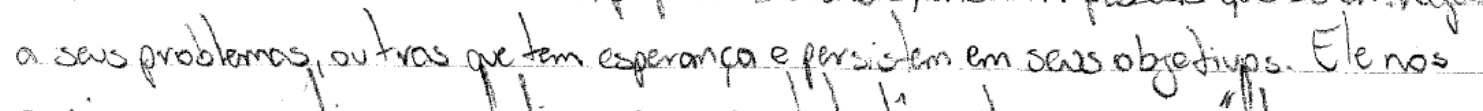

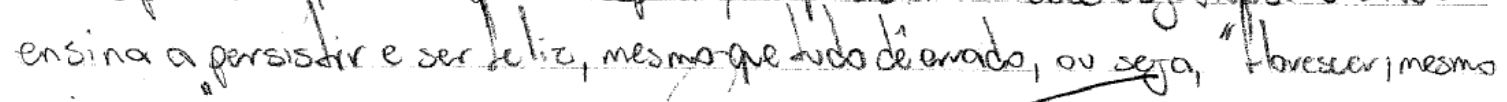
no inverno".

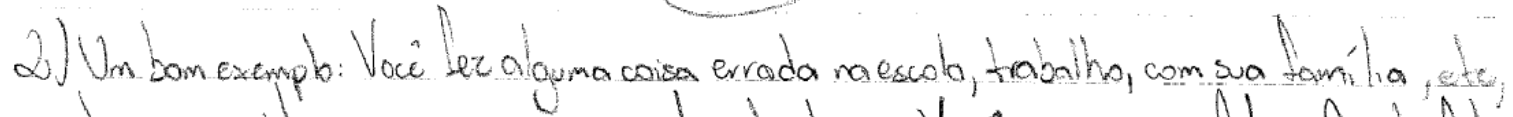
e sabe que vaitevar um esporro ou a lyo do tipo. Vocé permonece étiz. Aorda flicic, passa o cia telic e parmanece fel ic mesmo ag hrendo as ponsequéncios de seus

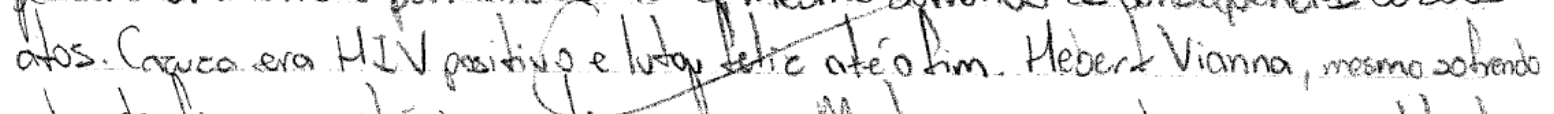

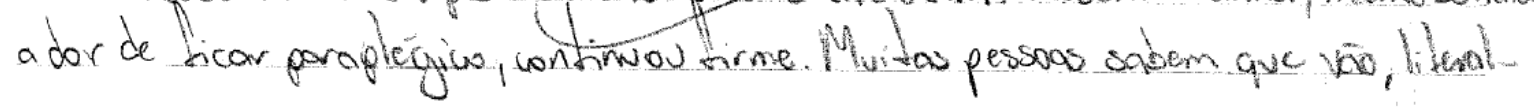


Produção de aluno,número 2

\section{6}

monk was bates

I. Fernando Eoxta.

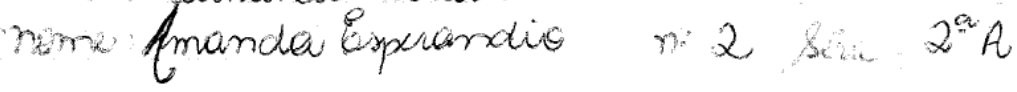

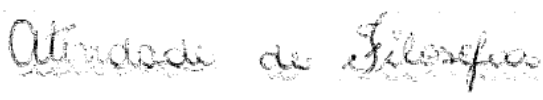

* Apér a lúturo de texto de Ruberr Ches:

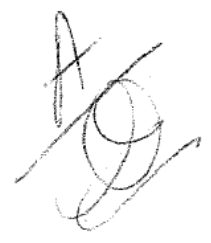

(1) Que tipe de anelegio vece faz ix texto com a prática dow vido real?

$B=$ A rebacos do tencto cen a thao nal, to que

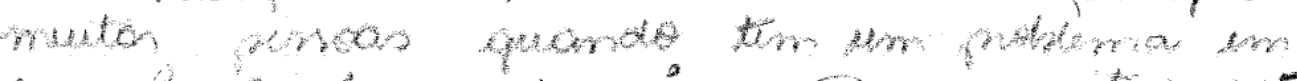

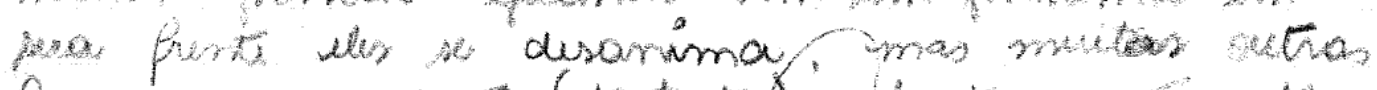

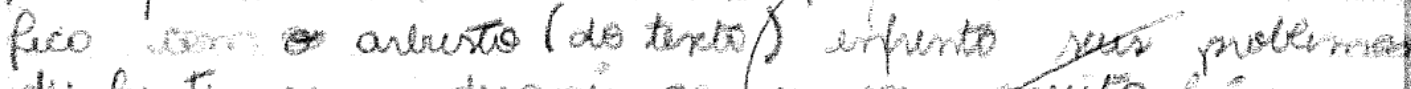

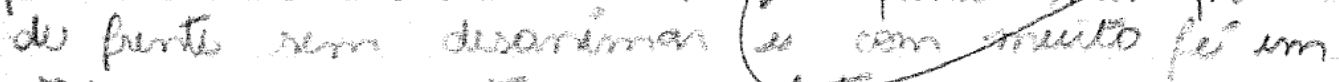

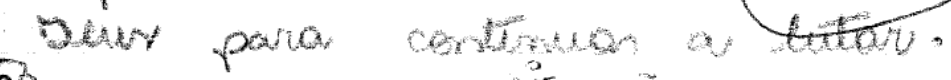

23. Duxreva uma situacä que exempleququer

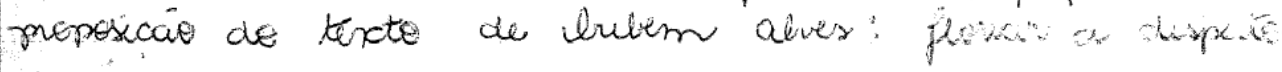
di incung.

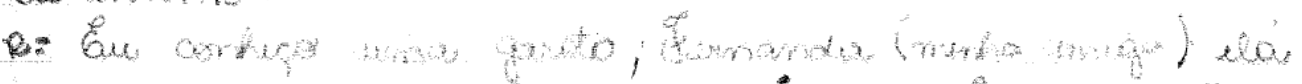

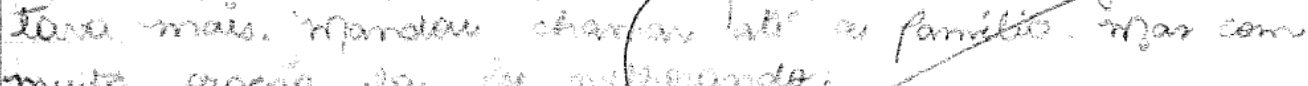

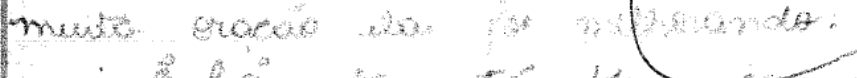

$$
\text { is hy by ato }
$$

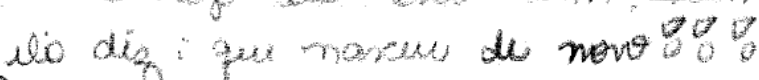

63 - dialacique fei um prefeta da bblia Ele paz uma linds oracáo mestrando teda a sua forca diante des moblemar. Faca vecé tambion una "elacão" come a de Habeucar completando on mellemas es obtáculo que tims no atualidade (drego, depussáe, mixivio, dusempogo viólêrcio) 
134

¿que apesar deles, vecé continuaró firme nor seis propósitos en ob́fitor de vida:

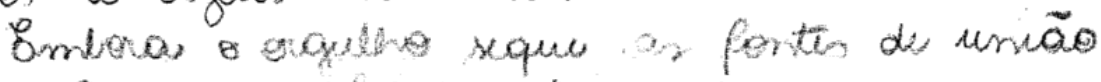
- amer prea estrubicade.

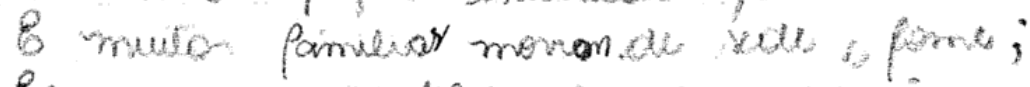

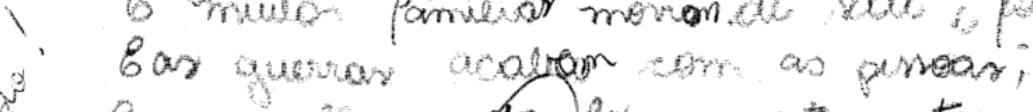

Oir

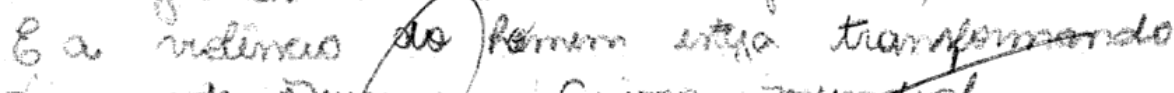
a pon de nup ism, guemo mundtial

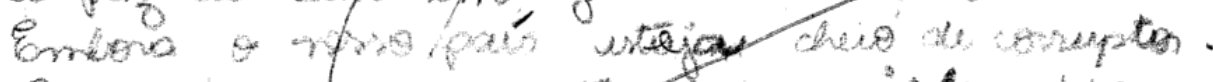
B apesar difro w contenthise a minha wido

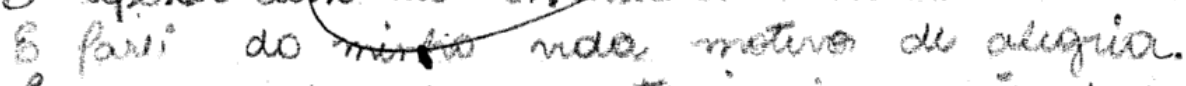

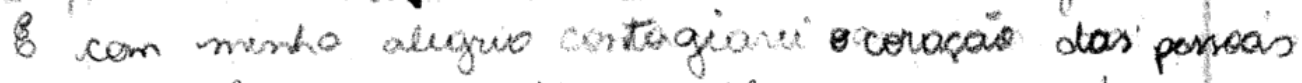
8. - Habacugue se fortalecue anto os problemar porque elo desindew um sentemento muito impostante que $e^{-}$ a vipronga.

5 - final do tento fala sone grande miservo". Nar sua spinucio, o que seria usse grande misterus?

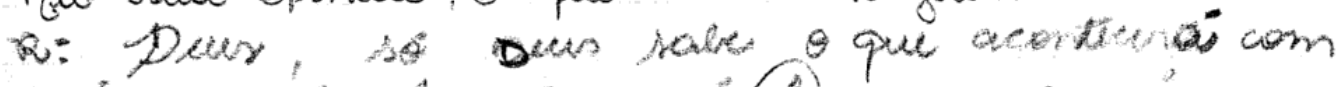

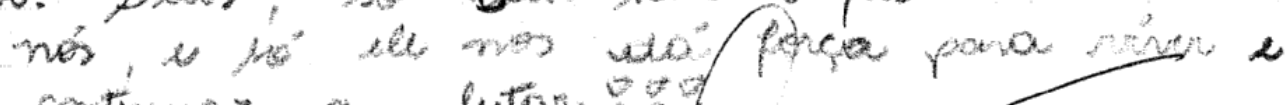
continuar a lutar 


\section{Produção de alunos, numero 3}

3) Bmbege, a velinera destrua jamelias a polveza domene países; a falta de arnor domine os homens, Bmbeva as querras ustuam acaudodo com a munto, row perderimos a usperarcat pois dias melhores virad,

4) Bspenanca.

5) A fí, a amor, todos sentimentes aue noo use rém mar neis de useram. 


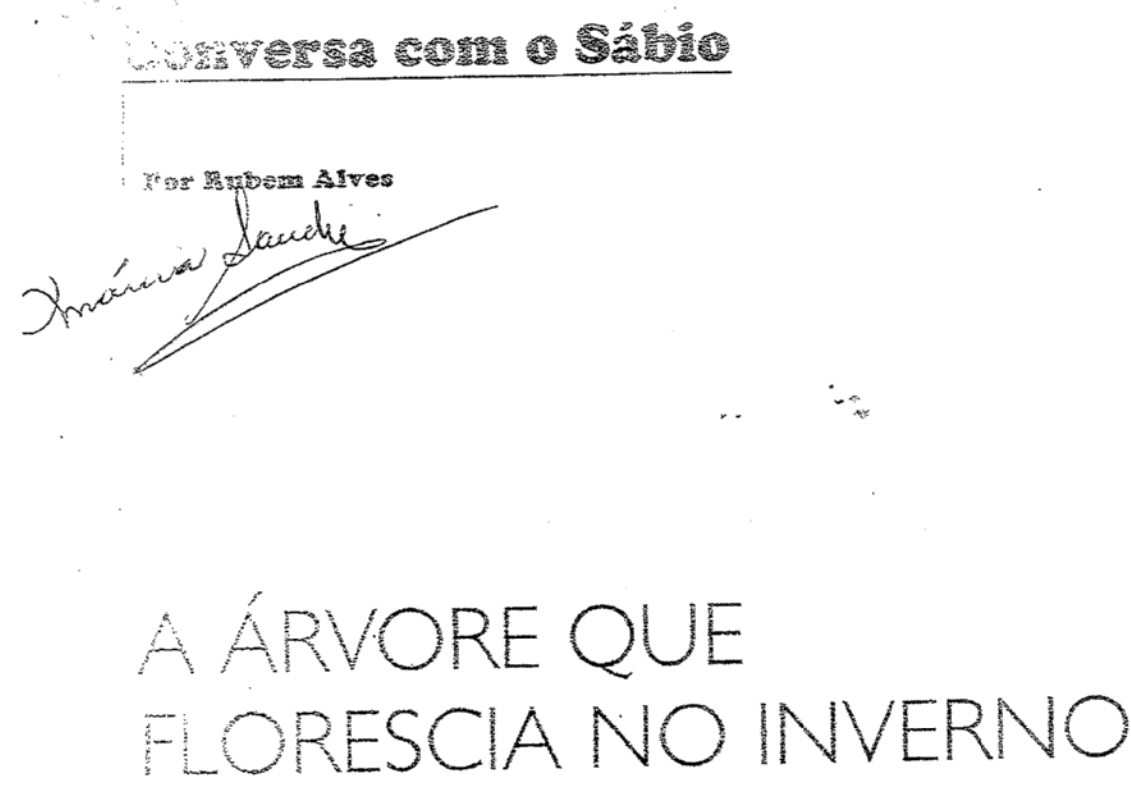

Como se saudasse uma primavera que, naquele momento, só existia em Densamento um arbusto teimoso dava flores em pleno inverno. Seus botões pareciem crianças desafiando a sisudez e o conformismo do mundo dos adultos.

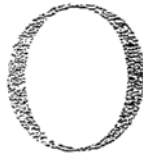

$s$ sinais eram inequíocos. Aquelas riurens baixas, escuras... $O$ vento que soprava teste a véspere, arancando das árins tothas amarelas e vermelhas. Vo qu tuam partir.. É, estava cheNo o inverno. Deveria nevar. Un eno a tristeza, as árvores peboi, a vida recolhida para fundua.s mais giuntes, os pássaros já aufiet frigidos para outro clima, e -.1iele longo sono da natureza, bo chic ouundo cai a primeira nevada, trit com o passar do tempo... Ruchi passear, para dizer adeus às fuths que se preparavam para Jumir s tui, assim, andando, enuntando-as silenciosas a confor:taưus fronte ao inevitável, 0 inver$\therefore$ qua se aproximava. Qualquer us xa seria inútil
Foi então que eu ine espantei ao ver um arbusto estranho. Se fosse um ser humano certamente o internariam num hospício, pois lhe faltava o senso da realidade, não sabia reconhecer os sinais do tempo. Lá estava ele, ignorando tudo, cheio de botōes, alguns deles já abrindo, como se a primavera estivesse chegando. Não resisti, e me aproveitando de que não houvesse ninguém por perto, comecei a converser com ele, e the perguntei se não percebia que o inverno estava chegando, que os seus botões seriam queimados pela neve naquela mesma tarde. Argumentei sobre a inutilidade daquilo tudo, um gesto tão fraco que não f2ria diferença alguma. Dentro em breve tudo estaria morto...

E ele me falou, naquela linguagem que só as plantas entendem. que 0 invemo de fora não the importava. o seu era um ribmo diferente, o ritmo das estações que havia dentro. Se era invemo do lado de fora, era primavera lá dentro dele, e seus botōes eram um testemunho da teimosia da vida que se compraz mesmo em fazer o gesto inútil. As razōes para isto? Puro prazer. Ah! Há tantas cançōes inúteis, fracas para entortar o cano das amas, para ressuscitar os mortos, para engravidar as virgens, mas não tem importância. elas continuam a ser cantadas pela alegria que contém... E há os gestos de amor, os nomes que se escrevern em troncos de árvores, preces silenciosas que ninguém escuta, corpos que se abraçam, árvores que se plantam para geraçōes futuras, lugates que ficam vazios, à espera do retomo, poemas inúteis 